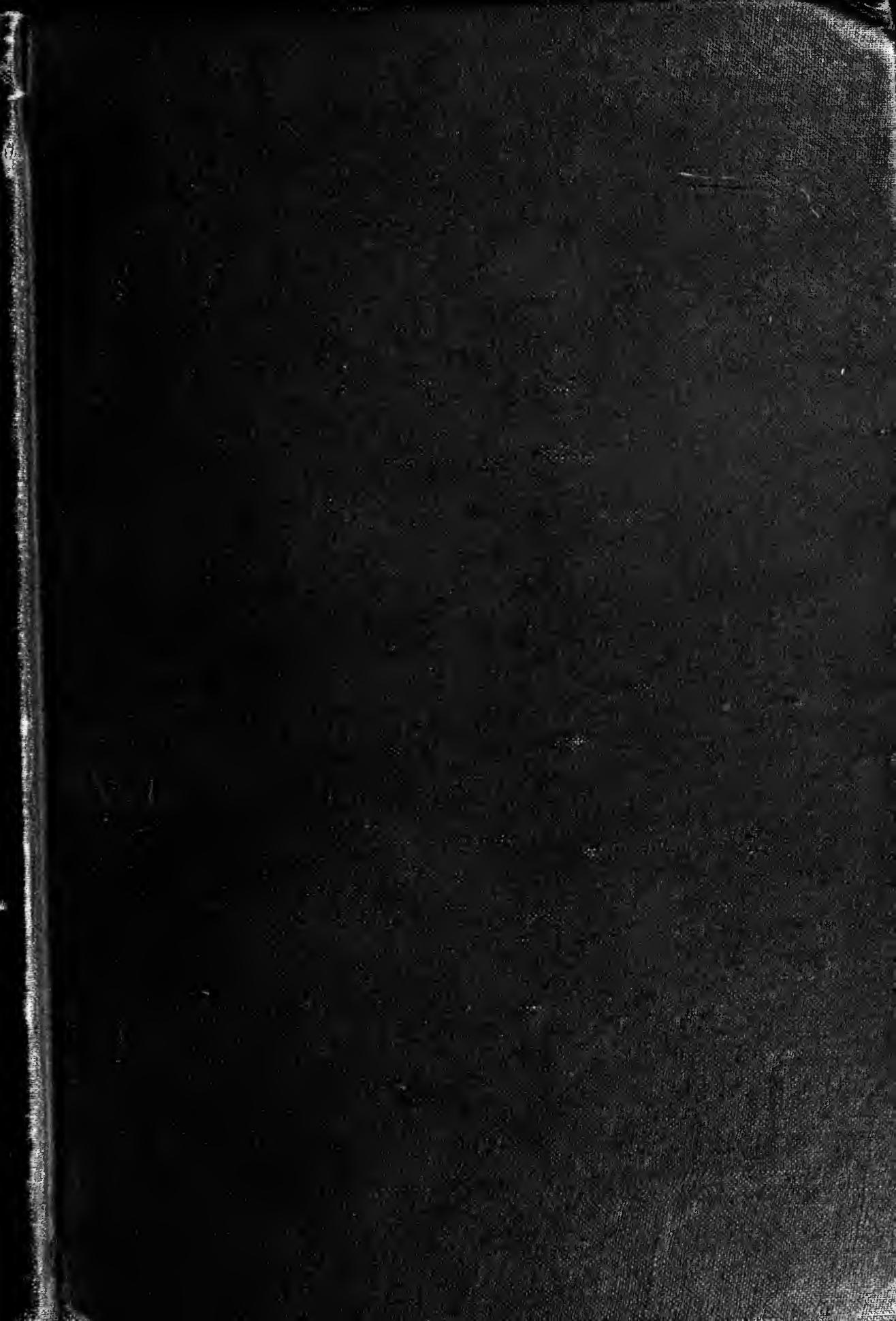

, . 


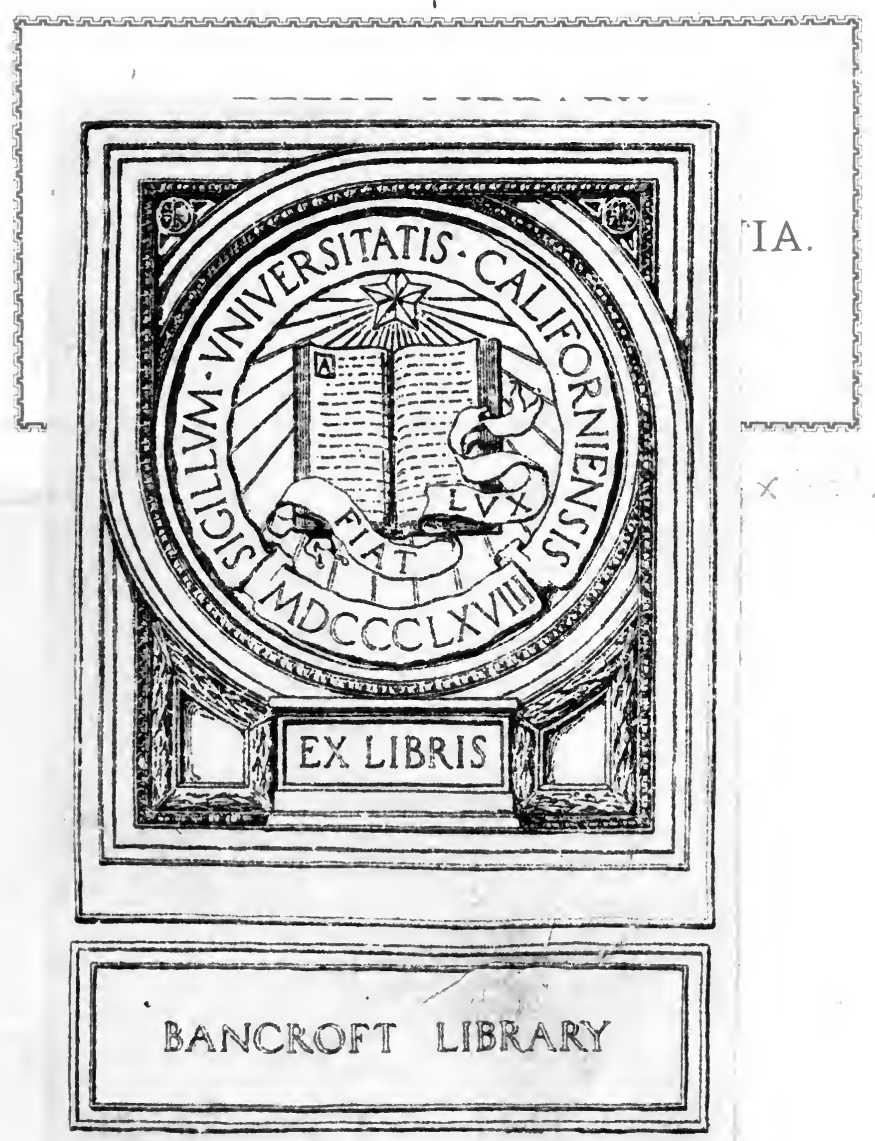




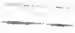


Digitized by the Internet Archive in 2007 with funding from Microsoft Corporation 


\title{
BRITISH INTERESTS
}

AND

\section{ACTIVITIES IN TEXAS}

\author{
1838-1846
}




\section{THE ALBERT SHAW LECTURES ON DIPLOMATIC HISTORY}

By the liberality of Albert Shaw, Ph.D., of New York City, the Johns Hopkins University has been enabled to provide an annual course of lectures on Diplomatic History. The courses are included in the regular work of the Department of History and are published under the direction of Professor John Martin Vincent. 


\section{THE ALBERT SHAW LECTURES ON}

DIPLOMATIC HISTORY, 1909

\section{BRITISH INTERESTS}

AND

\section{ACTIVITIES IN TEXAS}

$1838-1846$

By EPHRAIM DOUGLASS ADAMS, Ph.D.

Professor of History in Leland Stanford Jr. University

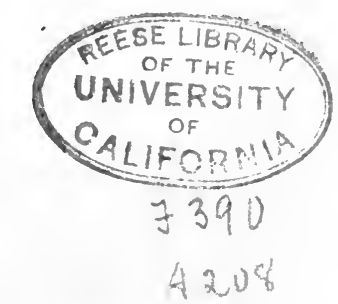

BALTIMORE

The Johns Hopkins Press

1910 


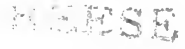 \\ $M<C$}

Copyright, rgro

By The Johns Hopkins Press 


\section{CONTENTS.}

Preface $\ldots \ldots \ldots \ldots \ldots \ldots \ldots \ldots \ldots \ldots$ vi

CHAPTER I.

First Indications of British Interest....... I 3

CHAPTER II.

The Negotiations of Treat and Hamilton.... 36

CHAPTER III.

i84i. British Recognition Postponed. Kennedy's Mission to Texas............ 6I

CHAPTER IV.

i842, January to June. The Montezuma and the Guadeloupe .............. 79

CHAPTER V.

1842, July to December. First British Offer of Mediation. Elliot in Texas... 97

CHAPTER VI.

1843. The Robinson Armistice and the London Abolition Meeting ............. I23

CHAPTER VII.

i844, January to June. The Calhoun-Pakenham Correspondence. Aberdeen's Plan to Prevent Annexation ............. 155 


\section{CHAPTER VIII.}

AberdeEn's Withdrawal from JoINt ACtion

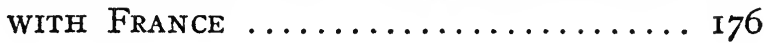

CHAPTER IX.

1845. Elliot's Mission to Mexico.......... I97

CHAPTER X.

1846. Texas Annexed. Conclusion ...... 219

CHAPTER XI.

Addendum. English Interest in the AnnexAtIon of CALIFornia . . . . . . . . . . 234 


\section{PREFACE.}

The material for the lectures included in this volume was gathered by research in the Public Record Office in London during the winter of 1907-1908. That time was spent in an examination of documents and correspondence connected with English-American relations from 1815 to 1855 , after which date they are inaccessible. Such papers are chiefly in the foreign office correspondence and, while they throw much light on many controverted points in history, they are nowhere more illuminating than in the matter of the British attitude toward the American annexation of Texas. Hence the invitation of the Department of History of the Johns Hopkins University to deliver the Albert Shaw Lectures in Diplomatic History in May, 1909, seemed to be most opportune and I gladly presented there the result of my work relating to Texas. This presentation is purely technical, and, while seeking to meet doubtful points, it depends upon documentary substantiation only. It might be indefinitely elaborated by citations from secondary authorities, or greatly bettered by a more complete portrayal of contemporary conditions. The purpose of the lectures forbade this. The California chapter, previously printed in the American Historical Review, is added because of its intimate connection with the Texan question.

Many friends have greatly aided me by suggestion and advice in the general field of English-American 
relations, but to these my thanks have been previously expressed and need not be intruded in this preface. Three there are, however, to whom so much of the profit of the work in England is due that they must again submit to the expression of my gratitude. The kindly services and interest of the Honorable Whitelaw Reid will always be remembered; Dr. J. Holland Rose saved me weeks of wearisome delay in getting access to needed documents by the care with which he guided my preliminary requests through the intricacies of official formality; and Mr. Hubert Hall of the Public Record Office extended, as always, that generous and scholarly aid which American students of history know so well. To these my thanks are again especially expressed.

Ephraim Douglass Adams.

Stanford University, California,

February I, I910. 


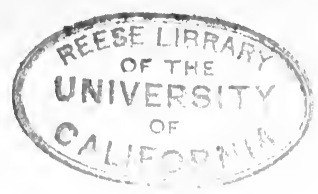

\section{CHAPTER I.}

\section{First Indications of British Interest.}

(Between the years 1840 and 1846 the question of 1 the extent of British interests in Texas and of British activities in relation to the independence of that State attracted much attention throughout the United States. The belief was prevalent that Great Britain was directly interfering in the affairs of Mexico and Texas for the purpose of preventing the annexation of Texas to the United States, of securing abolition within the State of Texas itself, and of thereby exercising an influence tending to the abolition of slavery within the United States.) That this belief in British intent and proposed interference existed there can be no doubt, and, admitting its existence, neither is there doubt of its influence and importance in shaping American national policy. By contemporary politicians, and particularly by those from the South, the idea that Great Britain was planning to intervene was urged with notable effect in the closing year of Tyler's administration, and it played an important part in the campaign that resulted in the election of Polk. The use made by Calhoun of what is known as the Pakenham-Calhoun correspondence, which relates the policy of Aberdeen, is of course well known, and at the time there was little question, save in extreme abolition circles, that the allegations of Calhoun had some foundation in fact.

Later historical judgment, however, has generally tended to deny the truth of contemporary opinion in 
this matter. Thus, Schouler regards Tyler and Calhoun as lacking in candor in attributing to Great Britain abolition designs upon Texas. Von Holst, who until recently had made the most extended examination of the whole question, similarly asserts the insincerity of Calhoun, though acknowledging the natural and logical grounds of any suspicion of Great Britain. $\mathrm{H}$. H. Bancroft goes beyond these two writers in denying that there was in the mind of the advisers of Great Britain any purpose whatever to secure abolition in Texas. The most recent work treating of 'American diplomacy under the administrations of $\mathrm{Ty}$ ler and Polk, written by Professor Reeves, and forming one of the series of Albert Shaw Lectures, asserts that Aberdeen was throughout this period the true friend of the United States. This last statement does not necessarily deny a policy of interference in Texas upon the part of Aberdeen, but it clearly leaves the inference that Aberdeen was accused upon insufficient grounds.

It is the purpose of the present work to offer the results of a recent study of British interests and activities in relation to Texas within the period from 1838 to 1846 . The materials for this were largely found in the diplomatic correspondence between British foreign ministers and their agents in Mexico, Texas, and the United States; in the recorded interviews with the representatives of these states in London; and in the private letters of many interested persons, addressed to the foreign office. All of this material is preserved at the Public Record Office in London, and with it, also, the complete records of the British consulates in Texas up to the annexation of that Republic by the United States. 
It is not the intention to present a general picture of British diplomacy in this period, or even to explain British interests in Mexico where those interests do not have a direct bearing upon what was attempted in Texas or in regard to that State. Nor is it intended to dwell upon, or to explain, the objects and diplomacy of Texas aside from their relation to British activities. The center of interest in this study is emphatically in the objects, activities, and accomplishments of the British goverment and its agents. Naturally the policy and acts of the United States in relation to Texas must be kept clearly in mind throughout, for an understanding of British action can be secured only by complete knowledge of the acts and efforts of the United States within the same period and by constant reference to them. It is fortunate that such matter was presented in a most scholarly and authoritative manner in 1906 by $\mathrm{Mr}$. Reeves, and in attempting to follow the explanations here given of British activities his volume will be invaluable.

In tracing the history of British interest in Texas, it is at once to be noted that the inception of that interest was connected with the traditional British policy of supporting Mexico as a barrier against the United States. This policy had the support of Canning as early as I825, and had been steadily continued by British foreign ministers after his time. Meanwhile, British commercial interests in Mexico were greatly extended, and Mexican trade had constantly increased. A large part of the Mexican debt was held by British bondholders. When, therefore, Texas declared her independence, on March 2, 1836, it was only natural that the British government should hope for a speedy re- 
conquest of the revolted province. This did not mean, however, that any active steps looking toward such a reconquest were taken by Palmerston, who was then foreign secretary, or that any such policy was publicly urged upon the English government. It was, in fact, quite generally recognized that the Mexican government had not given such evidence of strength as to warrant a positive belief in its permanence and stability. Still, the interest of Great Britain seemed unquestionably to lie upon the side of Mexico rather than upon the side of Texas. It was well understood in England that Texas would soon attempt to secure from other states a recognition of her independence, and before any such overture had been made to Great Britain the attention of the House of Commons was called to the situation in Texas by some of the avowed friends of Mexico. On June 5, 1836, Mr. Barlow Hoy brought up the question of the existence of slavery and the slave-trade in Texas, with a view to discovering whether or not the government had any purpose of interfering to check these evils. ${ }^{1}$ Palmerston replied that Texas was in a state of revolt, thus implying that for the present Great Britain could make no suggestions. Two months later, on August 5, Hoy brought the matter more directly before the Commons by introducing a motion instructing the government to take such measures as might be necessary to secure the fulfillment of existing treaties with Mexico "and prevent the establishment of slavery and traffic in slaves in the province of Texas." 2 In a speech supporting this motion Hoy emphasized as the essential

${ }^{1}$ Hansard, 3d Ser., XXXIV, IIo\%.

${ }^{2}$ Hansard, 3d Ser., XXXV, 928-942. 
interests of Great Britain in Mexico, first, the large $\nmid$ amount of British money invested in Mexican trade; second, the danger of the annexation of Texas by the United States, in which case England must consider "what vast commercial advantages the latter would gain over this country; " and third, the probability that slavery would be permanently established in Texas. + $\mathrm{He}$ asserted that it was wrong for Great Britain to "allow slavery to take deep root in situations with respect to which this country, had both the power and right to interfere in suppressing it." $\mathrm{He}$ concluded by urging Palmerston to send a naval force to aid Mexico in recovering control of the province of Texas. Other speakers urged that action was necessary in order to defend the commercial interests of Great Britain, and that England could not "allow the United States to pursue a system of aggrandizement."

The reply of Palmerston indicated that no serious attention had been aroused by Hoy's motion, for it stated that that motion was partly unnecessary and partly premature. Palmerston expressed disbelief in the existence of any extensive African slave-trade with Texas, evaded entirely the question of slavery within Texas, and asserted confidence in the integrity of the United States government, though acknowledging that the people of the United States, as distinguished from the government, had given real aid to Texas. He did not believe that the United States intended to annex Texas, but he added that if, in the future, there should be any evidence of such an intention, it "ought seriously to engage the attention of the House and of the British public."

The debate was of no real importance, nor does it 
indicate, perhaps, the positive sentiments or intentions of British officials. The fact that it is the only definite reference to Texas made for several years by the House of Commons indicates rather the general lack of public interest in the question. The tone of this brief debate, however, is interesting in that it shows a certain arrogant assumption on the part of Great Britain that she could easily settle the matter if she should care to interfere, while the points brought out by the speakers indicate even thus early the two main elements of later British opposition to the American annexation of Texas. One of these elements was philanthropic, being directed toward the question of slavery in Texas; the other was purely commercial and selfish, and turned upon the rivalry of Great Britain and the United States in the commercial development of the Gulf of Mexico. The points thus brought forward were later frequently cited in American newspapers as evidence of the real intentions of Great Britain in regard to Texas, while Palmerston's hint that British interests could not permit annexation served to irritate further a hypersensitive American public.

The recognition of Texas by the United States was delayed for some time upon various grounds, but was finally granted when a chargé d'affaires was sent to that State, on March 7, I837. Other countries were slower to recognize. It was undoubtedly a part of a plan for ultimate American annexation that British and French recognition of Texas should be secured, thus preparing the way for a denial of any right on the part of Mexico to resist annexation. Texas had, in fact, made a proposal to the United States for an- 
nexation, and had been definitely refused by Forsyth, the American secretary of state. This was in August of I837. Two months earlier, in June, General J. Pinckney Henderson had been sent to England for the purpose of securing English recognition. ${ }^{3} \mathrm{He}$ was well received, but the English government expressed no active interest in the matter, and finally, on December 27 , a definite refusal was given him. Meanwhile, however, the refusal of the United States to consider any annexation project and the subsequent withdrawal by Texas of its offer somewhat changed the situation. Palmerston was increasingly confident that American annexation plans were unlikely to meet with success. Yet he preferred to postpone British recognition, though willing to take steps looking toward it later on. Accordingly, he gave notice to Henderson that until the time for recognition should arrive, the trade of Texas "would be treated as a part of Mexico," and "vessels under the Texas flag or with clearances from Texas custom houses would be admitted into English ports under the terms of the commercial treaty between England and Mexico."4 This peculiar

${ }^{8}$ Henderson was born in North Carolina in 1808 , was admitted to the bar in 1829, and, after several years of practice, removed to Mississippi in 1835 . He soon became interested in the Texan revolution, joined the Texan army, and was appointed a brigadier-general. In 1837 he was elected secretary of state, and in 1839 was sent to Europe to secure foreign recognition. On his return to Texas in 1840 he resumed the practice of the law, but in 1844 was sent to Washington by President Houston as a special minister to negotiate a treaty of annexation. In 1846 he was elected governor of Texas. In 1858 he was appointed senator from Texas, and died in the same year at Washington.

"Worley, "Texas and British Designs," p. 5. In Texas State Hist. Assoc. Q., X, no. I. 
arrangement, by which a state regarded as in revolt from the parent state was given the trade privileges of the latter, did not satisfy the government of Texas in any respect, but was accepted as an indication of greater concessions to be made later. In truth, however, the real reason for the arrangement lay in the necessity for it felt by the British trade interest itself. Meanwhile Henderson, though disappointed with the results of his British mission, had proceeded to France, and had secured the recognition of Texas from that power.

The manuscript material in the British Public Record Office indicates clearly that in the years 1837 and 1838 very little interest was attached by diplomats to the situation in Texas. Palmerston sent to the minister in Mexico but one instruction referring to Texas, and that was merely to notify him that Henderson, the Texan envoy, had arrived in London, and that the British government had not as yet reached any decision with regard to Henderson's proposals. Yet as early as I837 considerable newspaper gossip in America accused Great Britain of a plan to acquire Texas by means of a transfer of the province by Mexico to the bondholders of the Mexican debt. The records of the foreign office contain no trace whatever of this purported sale or of any similar scheme. English interest was, in fact, almost wholly directed in this year toward the question of French reprisals then being undertaken against Mexico because of her refusals to adjust various French claims. Palmerston, reflecting this general British interest, yet desiring at the same time to preserve the good-will of France, was distinctly embarrassed by the French activities upon the coast of 
Mexico. British merchants were themselves extremely vexed at the delay of Mexico in meeting their own claims, ${ }^{5}$ and to this extent they sympathized with the claims of French merchants and the action of the French government. When, however, the French government sent a fleet to Mexico to blockade Mexican ports and force a settlement of French claims, the trade of Great Britain was seriously interfered with, and numerous complaints were made to the British government. ${ }^{6}$ Before France had fully prepared this plan of bringing pressure to bear upon Mexico, an agreement had been reached with Palmerston by which it was understood that the British fleet in the Gulf of Mexico was not to interfere with that of France, but the limits of French action had not been completely defined. The theory of France, acquiesced in by Palmerston, was that the expedition of the French squadron and its acts upon the coast of Mexico did not constitute war. When the French squadron actually blockaded Mexican ports, however, it was difficult to consider the situation as other than a warlike one. British merchants asserted that if war did not exist, they had a perfect right to clear their vessels for Mexican ports, and that the French squadron had no right to interfere with the entry of British vessels into such ports. Palmerston at first refused to listen to this argument, but the complaints became so numerous that he finally stated that British vessels might clear for some nearby " neutral " port with the idea that if upon arriving at such port the vessel should find no actual blockade before the Mexican port it desired to

'F. O. Mexico, II7.
'F. O. Mexico, I2I, Dom. Var. 
enter, it might proceed upon its journey and depend upon British protection in case of interference by the French." The use here of the word "neutral" was unfortunate, for the reply of the merchants promptly pointed out that if " neutral" ports existed in the case in question, then a state of war actually existed also between France and Mexico, and in that case only those Mexican ports actually closed by an efficient blockading squadron should be regarded as closed to British merchants. The difficulty of Palmerston was increased by the fact that in 1837 Great Britain had blockaded the coast of New Granada in exactly the same manner in which France was now blockading Mexico, and yet had asserted that no war existed. In the present case Palmerston finally took the advice of a queen's advocate, Hodson, and was told that in fact Great Britain had been at war with New Granada, and that France was now technically at war with Mexico. ${ }^{8}$

'Ibid., Palmerston to Powles, November 15, I838.

'Palmerston's action in regard to the French squadron upon the coast of Mexico is interesting. He had agreed with France not to interfere with this punitive expedition, and yet, at the same time, he did not wish it to appear to Mexico that he had made such an agreement. Great Britain was still regarded by Mexico as her chief support and most friendly adviser, and this was true in spite of recent irritating incidents which had arisen between the two countries. Palmerston therefore gave instructions to the Lords Commissioners of the Admiralty that the British squadron in the Gulf of Mexico, which was under the command of Sir Charles Paget, should not interfere with Admiral Baudin of the French navy, but that Paget was not to let Baudin know that he had such instructions. Paget was to cruise somewhere near the French squadron, keeping track of the operations of that squadron, and if he found that Baudin was going to bombard some Mexican fortresses upon the coast, then Paget was to withdraw conveniently, or be called away. Palmerston knew, in fact, that 
The importance of this episode and of British interest in it, both public and official, when considered in relation to British policy toward Texas, lies in the evidence it presents that as yet Mexico and Mexican trade relations occupied the center of the British stage. Texas had so far secured but scant attention from the British public or government. From Mexico itself, however, there came indications that British agents were more interested in the Texas situation than was the home government. Pakenham, the regular minister in Mexico, was in England upon leave of absence during a large part of 1837 and $1838 .{ }^{\circ}$ The reports of Ashburnham, Pakenham's substitute for this period,

the plan of the French squadron was to bombard San Juan de Ulúa as a punitive measure against Mexico. It was thus a somewhat involved instruction that was given to Paget. He was not to interfere with Baudin, yet Baudin was not to know that he had such instructions. He was not to be present when Baudin actually punished Mexico, so that Mexico should not understand that an agreement existed between England and France. Thus the "honor" of the British navy was to be preserved, as well as its prestige in the Gulf of Mexico, and the friendly relations of Great Britain and Mexico were not to be endangered. F. O. Mexico, I2I, Secret, Palmerston to Lords Commissioners of the Admiralty, October 9, 1838 .

- Sir Richard Pakenham, born in I797, spent nearly all of his mature life in the British diplomatic service. He was educated at Trinity College, Dublin, and in I8I7 was attached to the embassy at The Hague. After some years of service in European posts he became, in 1826, secretary of legation at Mexico, and in 1835 was made minister there. In December, 1843, while in England on leave of absence, he was appointed minister plenipotentiary to the United States, retiring from this post in 1847, and retiring from the service rather than return to the United States, where he thought he had not been well treated. He later reentered the service in $185 \mathrm{I}$ as minister at Lisbon, but retired permanently in 1855 . He died in 1868 . 
furnish clear proof of the activity of Great Britain at this time in offering advice to the Mexican government, and even in attempting to impose a policy. The tone of British ministers in Mexico, apparent in their despatches, shows distinctly Great Britain's assumption of the right to advise and her exercise of that right in a way that would have been resented by a stronger power. This advice was constantly given upon questions of both domestic and foreign policy, yet Ashburnham clearly pictured the hopeless weakness of the Mexican government and the disturbing revolutionary elements, and frankly conceded the impossibility of a payment by Mexico to her English bondholders.

It is in this connection that the situation in Texas received notice, for Ashburnham favored British recognition of Texas upon the grounds that Mexico could not possibly reconquer that province and that Texas, if recognized, might perhaps do something for English creditors. He also pointed out that so long as any hope existed in Mexico of the recovery of Texas there would be disorders and disturbances within Mexico itself, and he volunteered the opinion that even if Texas were reconquered, Mexico "would be wholly incapable of checking the slave-trade there."10 His despatch outlining these ideas was received at the foreign office at the moment when that office was considering the acts of the French upon the Mexican coast and the complaints of the British shippers arising therefrom. For this reason no attention was paid to it. In October, I838, Pakenham set out upon his re-

\footnotetext{
${ }^{10}$ F. O. Mexico, II4, Ashburnham to Palmerston, June 24, I838.
} 
turn to Mexico, and the written instructions given to him treated mainly of the relations with the French and of the compromise which he was to suggest for the purpose of settling French-Mexican difficulties. He had, however, verbal instructions with regard to Texas which will appear in his acts in Mexico in the next year. ${ }^{11}$ It is clear therefore that Palmerston was not ready as yet to take up seriously the question of the recognition of Texas. Henderson, after his first failure in London, had gone to Paris, and succeeded a little later in securing French recognition. He then returned to Texas. It was at this point that diplomatic representatives of the United States in Europe first evinced a direct interest in securing British recognition for Texas. Cass, the United States minister at Paris, urged Henderson, by letter, to secure the recognition of some continental governments if possible and thus bring pressure to bear upon England. But for some time nothing came of this suggestion. Thus the year 1838 closed without any evidence of a real interest in Texas on the part of Great Britain.

During the summer of 1839 there began in Mexico that series of suggestions looking toward pacification

${ }^{11}$ The customary historical treatment of the American claims urged upon Mexico some years earlier is to assert that President Jackson used unwarranted pressure upon Mexico in demanding satisfaction of such claims, and that he did this for the purpose of bringing about a relation between the United States and Mexico favorable to an American annexation of Texas. Considered in the light of what France actually did in the year 1838 and of the support given to French action by Great Britain, the pressure exerted by Jackson does not seem excessive, and the accusation of an ulterior motive needs greater proof than has yet been given of it. 
and recognition which until $\mathrm{I} 846$ occupies a large part of the correspondence from the British minister in Mexico. These suggestions were various. Some of them resulted in definite attempts upon the part of British agents to bring about a permanent peace between the two states. All of them involved more or less the same ideas and somewhat the same plans, and the story of them will therefore require a certain amount of repetition. This is, however, necessary in order to understand clearly in each year just what was the attitude of the British government and its agents.

Pakenham had arrived in Mexico early in the spring of I839. In May he received a letter from a Mr. Gordon, of New Orleans, ${ }^{12}$ outlining a plan which was to be presented at the hands of a Mr. Bee, the Texan secretary of state under Lamar's presidency. Gordon was a representative of the house of Lizardi and Company, a British firm which more than any other was held to represent the commercial interests of Mexico in London. Lizardi and Company were directly occupied also in attempting to secure payment for the English bondholders of the Mexican debt. Thus Gordon, in writing to Pakenham, may be understood to have had in mind, first, the interest of the bondholders, second, the interests of Mexico, and only indirectly the interest of Texas. In his letter to Pakenham, Gordon stated that he had no admiration for the Texans, but that there was no prospect of a Mexican reconquest of the province, and that Mexico must therefore make the best of a bad situation and drive the best bargain possible with the Texan government. He wrote that ${ }^{12}$ F. O. Mexico, I25, Gordon to Pakenham, April 29, 1839. 
Bee was prepared to offer five million dollars for the recognition of Texan independence, but upon condition that the Texan boundary should be advanced from the Nueces to the Rio Grande. Gordon therefore proposed that Mexico should satisfy the claim of the English bondholders to the extent of five million dollars by locating lands for them within the disputed territory between these rivers, accepting the five million dollars from Texas, and then agreeing to the line claimed by Texas. This, he urged, would be a good business operation for Mexico, would give the bondholders the exact territory they desired, and would be of great benefit to Texas inasmuch as it would bring into this particular territory a large number of English and Dutch settlers.

Upon the receipt of this letter from Gordon, Pakenham made inquiries of the Mexican government, and outlined the suggestions made in the letter, but he found that Bee had already been notified by that government that Mexico would have nothing to do with any project involving the recognition of Texas, and that this reply had been made even without waiting to hear what Bee had to propose. Pakenham, in his despatch to Palmerston reporting this matter, stated that this had seemed to him a proper opportunity to carry out the verbal instructions given him by $\mathrm{Pal}-$ merston at their last interview just previous to Pakenham's departure for Mexico. ${ }^{13}$ The interview had occurred in October, 1838, and Pakenham's report of what he now urged upon the Mexican government thus indicates Palmerston's project in that month.

Pakenham urged the importance of a prompt recog${ }^{13}$ F. O. Mexico, I25, Pakenham to Palmerston, June 3, I839. 
nition of Texan independence, laying stress upon the advantage to Mexico when there should be a barrier state between it and the United States. Gorostiza, the foreign minister, replied that he agreed perfectly as to the importance of such an arrangement, but that the Mexican government dared not risk so unpopular an act, and he hinted that as a preliminary to a possible future recognition Mexico might welcome from England a suggestion for a suspension of hostilities. In reply to this, Pakenham was very cautious, but stated that England would probably be willing to suggest an armistice if previously assured that Texas sincerely desired it. In regard to the boundary desired by Texas, Gorostiza asserted that Mexico would never consent to such limits, and that if a boundary were some day fixed, it would be desirable to have it "guaranteed by some powerful European government." "I thought," wrote Pakenham, "I might at once assure him that no European power would be found willing to undertake the responsibility of such a guaranty." At the conclusion of his despatch, Pakenham summed up the situation: "Reconquest is admitted to be impossible, and yet a feeling of mistaken pride, foolishly called regard for the National honor, deters the Government from putting an end to a state of things highly prejudicial to the interests of Texas and attended with no sort of advantage to this Country."

In spite of the unfavorable outcome of the interview, Pakenham believed that the offer of five million dollars, if really made, would prove too tempting a bait for the Mexican government. In his reply to Gordon ${ }^{14}$ he spoke encouragingly of the Texan offer, and wrote that

${ }^{14}$ F. O. Mexico, 125, Pakenham to Gordon, June 2, 1839. 
Texas must " not be discouraged by the failure of this first attempt." Without question, Pakenham was himself perfectly convinced of the impossibility of a reconquest of Texas by Mexico, and he was at this period very much impressed with the potential strength of the new State. He believed that Texas would have a very rapid development, and that British interest demanded active efforts to secure its friendship. He was, in short, at the moment wholly in favor of an independent Texas and of offering British aid to the State, being willing to go so far, if necessary, as to endanger the good feeling existing between England and Mexico. There is much more evidence along these lines in the following year, but it is certain that Pakenham, even in the summer of 1839, was a firm believer in the future of Texas. The verbal instructions of Palmerston in October of 1838 indicate also that the British government, or at least the head of the foreign office, was already convinced that Mexican recognition of Texas must come. It is noteworthy, however, that there is nothing in this correspondence even hinting at the question of slavery in Texas as offering an excuse for a refusal upon the part of any power to recognize that State.

The first written instruction upon the subject of Texas bears the date of April 25, I839, and was sent by Palmerston to Pakenham after the receipt of Pakenham's report of his overture of the preceding year. ${ }^{15}$ In this letter Palmerston entered at some length into the question of Texan independence. He argued the impossibility of a reconquest of the province, and called attention to the fact that the settlers in Texas were

${ }^{15}$ F. O. Mexico, 122. 
largely Americans and would be sure to receive the support of the citizens of the border states if Mexico pressed the war. He asserted that the population of Texas was so wholly different from that of the rest of Mexico that Texas, even if reconquered, would always be a foreign element, and could never actually be assimilated. Mexico was urged to spend her energy rather in rendering productive other portions of her vast territory as yet undeveloped. This would be her true domestic policy, while her foreign policy would be best served by the existence of a buffer state between herself and the United States. These were the customary arguments, or at least were to be those ordinarily used in bringing pressure to bear upon Mexico, but Palmerston urged also that now was the time to recognize Texas, since otherwise the people of that province "might throw themselves upon the United States for assistance, and their final incorporation with the Union might be a consequence of temporary cooperation." Palmerston expanded this argument in various ways, and concluded it by declaring that Texas, if independent, would really be thrown upon the support of Mexico:-

Such a State, being weaker than the N. American Union, would be more likely to connect itself with Mexico for defence, than to enter into League with the United States for aggression.

In matters of Trade, also, its Interests would in many respects harmonize with those of Mexico, and taking therefore into consideration all the various bearings of the Question, it may well be doubted, whether, the country which now bears the name of Texas could be placed in a position more advantageous on the whole to the Interests of Mexico than by becoming an independent State. 
In supplementary instructions sent to Pakenham, in this same letter, it appears that Palmerston did not really expect that Mexico would be willing to listen immediately to advice looking toward recognition, but that he did hope Mexico might accept an offer upon the part of Great Britain to exercise her good offices in bringing about a pacification. There is no documentary evidence to show what was the real reason animating Palmerston in thus urging recognition upon Mexico. Presumably his reason was an acceptance of the inevitable and a desire to make the best of it. $\mathrm{He}$ had, of course, long before this heard from General Henderson all the Texan arguments in favor of independence, but had declined, as yet, to grant British recognition. On the other hand, Hamilton, who in this same year was to secure from the British government treaties which, when ratified, involved British recognition, had not yet arrived in England when this instruction was written. The English argument here is based largely upon a fear of the expansion of the United States toward the southwest. The argument urged upon Mexico that the trade interests of Mexico and Texas were identical and were, in a sense, opposed to the trade interests of the United States was not well founded, for Mexico had abolished slavery, while Texas, both before and after its declaration of independence, was importing a considerable number of slaves. Palmerston, however, had made no mention of the subject of slavery, and it will be remembered that Ashburnham had previously informed him that slavery had become a permanent institution in Texas. Free labor in Mexico and slavery in Texas prohibited any real community of trade interests. 
Soon after the receipt of Palmerston's instructions Pakenham reported a change in the government of Mexico. Can̂edo, the new minister of foreign affairs, acknowledged that the arguments advanced by $\mathrm{Pal}-$ merston were sound, and stated that he was ready to take the risk of accepting Great Britain's offer of services looking toward an armistice if his colleagues would support him. Meanwhile, however, he urged that Pakenham should not press the matter until the new government had become more firmly established. Before this, Pakenham received a second letter from Gordon, at New Orleans, urging that a renewed effort be made upon the line of Bee's overture. Gordon stated that Texas could at any time get eight or ten thousand adventurers from the United States to join her army. He had told Bee that this scheme of granting to the British bondholders rights in the disputed territory of Mexico ought to be acceptable to the Texan government, and Bee had replied that he was sure no objection to it would be presented. With Gordon's letter to Pakenham there came one from Bee as well in which it was asserted that the Texan government was rapidly finding support from British investors and that a Texan navy would soon be in control of the Gulf of Mexico. ${ }^{16}$ Bee represented Texas as very anxious for peace but perfectly able to wage energetic war. ${ }^{17}$

${ }^{16}$ F. O. Mexico, I26, Pakenham to Palmerston, September I2, 1839; Gordon to Pakenham, August 2, 1839; Bee to Gordon, July 28 , I839.

${ }^{27} \mathrm{He}$ reported that six vessels were being built at Baltimore and that the money for them had been advanced by an English house, the Dawsons. He also stated that a Mr. Halford, an English merchant, had advanced $\$ 70,000$ for the purchase 
During the course of September Pakenham felt sure that he would soon be authorized by Canedo to propose to Texas a cessation of hostilities, and that this was but a step in preparing the country for recognition. If Texas were really willing to pay cash for her independence, Pakenham thought it possible that this might be secured with comparative ease. ${ }^{18}$ In this as in the former case, however, Pakenham found himself being sounded upon the question of whether or not-Great Britain would guarantee a boundary line between Texas and Mexico, and he again positively refused to entertain such a project. But at the moment, this second opening coming through Gordon and Bee had no result, for before the year was out Pakenham was engaged in what seemed a more promising arrangement, suggested, this time, by authorized agents of the Texan Republic. Gordon's proposals, then, merely served to pave the way for those later made by General James Hamilton.

During the early years, when British representatives in Mexico were busied in presenting to the Mexican government the advantages of peace with Texas, always with slight encouragement, but with apparent confidence that ultimate success was certain, England herself was asking damages of the Texan government. The British claim was pending during 1838,1839 , and

of a steamer, and that General Hamilton had secured from another English house a loan of half a million dollars. These matters were largely based upon rumors, and Bee evidently could not prove the truth of his declarations, but such statements were likely to have an influence upon British official agents.

${ }^{18}$ F. O. Mexico, 126, Pakenham to Palmerston, September I2, I839. 
I840, and was based on what were regarded as unjust acts of the Texan navy. These difficulties arose over the cases of the "Little Penn" and the "Eliza Russell." The former was a British schooner which, on a trip from Liverpool to Tabasco, had the misfortune to run aground on the Alacranes shoal off the Yucatan coast. This was in midsummer of 1837 . Lizardi and Company were the owners of her cargo, which was consigned to a citizen of Mexico. The schooner could not be saved, and two Mexican vessels were sent out to take off her cargo. One of these vessels, the "Abispa," was captured by two Texan ships of war, the "Brutus" and the "Invincible," and was sent into a Texan port, where the vessel and cargo were adjudged lawful prize. Lizardi and Company submitted a claim for damages to the British government

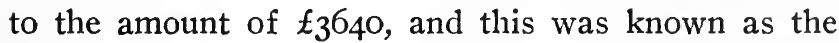
claim of the "Little Penn." The "Eliza Russell" was also a British schooner bound from Liverpool to Sisal, Mexico, and her cargo was consigned to Mexicans at their own risk. The vessel was captured on August 3 and sent into the port of Galveston, but was later released by order of the government. The delay, however, and some injuries sustained by the vessel led her captain to present a claim for 1865 damages, caused by the detention. Texas acknowledged that her officers had been at fault in this case and promised to pay the claim, but from various causes payment was long delayed and was not finally made until 1843. In the case of the "Little Penn" Texas maintained that no claim for damages was permissible, and undoubtedly the connection of Lizardi and Company with Mexico-a fact well known to the 
Texan authorities-operated disadvantageously to the claimants. Palmerston had pressed both these claims upon the attention of Henderson in 1838 and again in 1839 , but while using fairly vigorous language, he did not actually push the matter. On February 15, 1840, he instructed Pakenham to press these claims upon the attention of General Hamilton, with whom Pakenham had been corresponding upon other matters, but this instruction from Palmerston seems to have been a perfunctory formality to satisfy the claimants rather than a vigorous demand. ${ }^{19}$ It also appears from this instruction that Great Britain herself had reduced the amounts claimed by the owners of the vessels, plainly with a desire to be perfectly just and fair toward Texas. Unquestionably Palmerston was opposed to pushing any claims that could weaken British influence upon the government of Texas. Judged by the bulk of correspondence, the affair of the "Little Penn" was really important, and appeared to threaten friendly relations between Great Britain and Texas; in fact, it was never forcibly pressed by the British government, and did not seriously endanger those relations.

${ }^{10}$ F. O. Mexico, I33. 


\section{CHAPTER II.}

\section{The Negotiations of Treat and Hamilton.}

In December of 1839 General James Hamilton, of South Carolina, who had long interested himself in the affairs of Texas and who had already acted as a Texan financial agent abroad, set out for Europe for the purpose of disposing of bonds of the Republic, and also with the plan of securing treaties of recognition with various powers. ${ }^{1}$ Before undertaking the journey he had opened a correspondence with Pakenham, writing from New Orleans. Hamilton introduced himself to Pakenham by stating the results of his recent mission to France, largely taking to himself the credit properly belonging to Henderson of having secured recognition

${ }^{1}$ Hamilton was a man of unusual ability and energy, and played an important rôle both in his own State-South Carolina-and later in Texas. He was born in 1786 , being the son of a favorite aide of Washington's, was educated for the law, and took part in state and national politics. He was mayor of Charleston, South Carolina, was a member of Congress from I822 to I829, and was governor of his State, retiring when Hayne was inaugurated in 1830. Hamilton had supported Jackson's candidacy for the presidency, but was a strong states' right man and free-trader, and advised armed opposisition to the tariff of 1828 . Disgusted with the failure of the nullification movement, he removed to Texas, and quickly became an important factor there, serving as the financial agent of the State in Europe, and proving exceptionally fertile in plans for securing moneyed support in European centers. In 1857 Hamilton was elected to the United States Senate from Texas, but lost his life in a collision at sea on his way. to Washington, chivalrously refusing to enter a life-boat, and giving his place to a lady passenger. 
from that state. He narrated an interview which he had had with Palmerston in September of 1839 , in the course of which Palmerston had declared his belief in the permanency of Texan independence, and had asserted that Great Britain only awaited the results of her friendly offer of mediation to Mexico before recognizing Texas. He further stated that while in London he had been waited upon by a committee representing the Mexican bondholders, and had learned that Mexico had already given the bondholders a lien on the territory on the Rio Grande which Texas regarded as a part of her own soil. Hamilton now proposed, therefore, that Mexico acknowledge the independence of Texas and receive from Texas the sum of five million dollars, with the understanding that this amount should go directly into the pockets of the bondholders. The bondholders were then to release to the State of Texas the lands already granted to them by the government of Mexico.

This proposition was evidently much the same as that which had been brought by Bee to Pakenham, but with the difference that in this case Mexico's profit in the matter was to be merely a release from five millions of indebtedness instead of, as in the Bee proposition, the actual handling of that amount of cash. Hamilton further suggested that peace negotiations be begun at once in London, so that " the Mexican bondholders would thus on the spot be enabled under the protection of your Government to take care of their own interests.", Yet Hamilton was not prepared to state that Texas would positively acquiesce in such an arrangement. $\mathrm{He}$ posed here rather as a man

${ }^{2}$ F. O. Mexico, I34. 
about to undertake a mission to England, who had discovered a way out of a difficult situation, and was presenting the scheme for Pakenham's consideration. Nevertheless, in this same letter he notified Pakenham that a Mr. James Treat was on his way to Vera Cruz and would have further information to place at his disposal.

On December I2 Pakenham replied to Hamilton, expressing interest in the general plan suggested, but asserting his own conviction that all such plans for a definite conclusion of peace would be of no avail, and that the first logical and reasonable step to be taken was to arrange an armistice between the two nations. In spite of his own belief that matters could be satisfactorily arranged, Pakenham told Hamilton that Can̂edo had not yet promised to listen to any Texan proposition for an armistice, and had definitely asserted "that no proposition for the alienation of the right of sovereignty would be entertained." 3 So far, however, the Mexican government had refused to put in writing its final determination one way or the other, and Pakenham still hoped that it would make concessions in some reasonable and logical way. A little later Hamilton was notified by Pakenham that Can̂edo had at last given him a written communication indicating the willingness of the Mexican government to consider an offer of armistice from Texas. Commenting upon Mexican conditions, in a letter to Hamilton, Pakenham was surprisingly frank; he expressed his belief in the weakness of the government, condemned its vacillation, and predicted its total inability to reconquer Texas. He told Hamilton that use might be

${ }^{3}$ F. O. Mexico, 134 . 
made of any information conveyed to him, save that the written communication of Can̂edo, offering to receive a proposition of armistice, must be regarded as confidential, since it was essential to the prestige of the Mexican government at home that the offer should seem to come from Texas.

All this correspondence was transmitted by Pakenham to Palmerston on January $15,1840,4$ and it is quite clear that Pakenham was more hopeful of a favorable outcome for Hamilton's scheme than he had been willing to admit to Hamilton himself. $\mathrm{He}$ did not think, however, that Mexico would be brought easily to a final relinquishment of sovereignty over the territory desired by Texas on the Rio Grande, nor did he believe that the Mexican government would so easily let five million dollars slip through its fingers. Apparently, Pakenham had less interest in securing repayment for the British bondholders than Hamilton supposed him to have.

Palmerston gave a brief but complete approval to the acts and plans of Pakenham, emphasizing particularly the necessity of an armistice as preliminary to a permanent peace. ${ }^{5}$ In the meantime further letters had been exchanged between New Orleans and the City of Mexico. On January 2 Hamilton, before receiving Pakenham's first letter, had written describing a trip to Austin and its results. $\mathrm{He}$ asserted that Texas was decidedly in earnest in its desire for peace and that it was willing to pay money in order to secure it, but its pride required that the money go to the

'F. O. Mexico, I34.

-F. O. Mexico, I33, Palmerston to Pakenham, March I6, I840. 
40 THE NEGOTIATIONS OF TREAT AND HAMILTON.

English bondholders rather than into the hands of the Mexicans. He now wrote that he had full power to carry through and conclude a treaty, and he sent a memorandum, confidentially, of certain resolutions of the Texan Congress. He dwelt at length upon the sum of money to be granted, and maintained that it was well worth an effort on the part of the British government. He pictured Texas as holding her citizens in check for the present, but only for the present. $\mathrm{He}$ believed that, should Mexico refuse to negotiate, the rein would be loosened and Texas citizens permitted to cross the border and revolutionize the adjacent provinces of Mexico. A day later, on January 3, he had received Pakenham's first letter of December 12, and in reply stated emphatically that Texas would accept no armistice which did not include a secret article providing for a negotiation either at London or at Washington, as Mexico preferred. The secret joint resolution of the Texan Congress, transmitted by Hamilton, approved President Lamar's policy of peace, invested Lamar with power to appoint peace commissioners with authority to settle the boundary, authorized the placing of the loan to carry out the financial terms of the treaty, and concluded in the following words: " $\mathrm{Be}$ it further resolved that the said commissioners appointed on the part of Texas shall, if practicable, procure the guaranty of Great Britain, for the faithful performance of the Treaty by both Parties."

Pakenham's report of the affair to Palmerston be-

${ }^{6} \mathrm{~F}$. O. Mexico, 134. The document was signed by David S. Kaufman for the House of Representatives, by David G. Burnet for the Senate, and was approved by Mirabeau B. Lamar. 
trayed some apprehension in regard to Hamilton's fast-moving diplomacy as well as considerable skepticism as to the trustworthiness of his authority from Texas. ${ }^{7}$ Personally, he believed it impossible at the moment to get from the government of Mexico a pledge for more than an armistice. His theory was that an armistice would help Texas toward ultimate recognition, and that recognition itself must come by a gradual process. Not having any evidence other than Hamilton's own word that he had authority to carry through the arrangement proposed, Pakenham refused to present, in his official capacity, the case as outlined by the Texan government. In the meantime, Mr. Treat, spoken of in Hamilton's earlier letter, had arrived and asserted that he himself had authority to enter into negotiations with Mexico, but Treat also was without written credentials. Treat's personality, however, so impressed Pakenham that he wrote of him to Palmerston as "perfectly qualified for the task confided to him," and as having intelligence, good sense, and a good knowledge of the language and customs of Mexico, as well as an intimate acquaintance with conditions in Central America. Under the influence of this personal liking Pakenham ventured to secure for Treat an interview with Canedo, but this was unofficial because of Treat's lack of definite credentials. Can̂edo offered to receive Treat officially if Pakenham would " undertake to guaranty the validity of his credentials," but this Pakenham declined to do. He did, however, induce Can̂edo "to agree that whatever proposal Mr. Treat may be authorized to make will be

'F. O. Mexico, I34, February 9, 1840, with copies of his correspondence with Hamilton and of the Texan documents. 
received from me if presented as on behalf of the People of Texas."8

One most interesting feature of these various proposals, whether from Mexico or from Texas, is that pertaining to the suggested guarantee by Great Britain of a boundary between Texas and Mexico. It is perfectly clear that this suggestion did not originate with Pakenham, but came in the one case from Mexico, in the other, from Texas. Pakenham did not for a moment permit either party to be deceived upon this point, and in writing of this latest proposal to Palmerston, he stated, "Without Instructions from Your Lordship to that effect, I shall encourage in no quarter the expectation that her Majesty's Government will consent to guaranty any transaction that may be concluded between this country and Texas."9

Palmerston was equally clear in his instructions to Pakenham upon this same point, for upon May 14, in 184 reply to the communication from Pakenham just noted, he wrote, "I have at the same time to instruct you to explain distinctly both to the Mexican Govt. and to the Texan Agents that Great Britain cannot guarantee any arrangement between Mexico and Texas."10 Treat's arrival at Mexico did not mean the immediate renewal of negotiations, for it was necessary to wait until he should have secured proper credentials. These came in April, and at the same time Pakenham received a personal letter from David G. Burnet, acting secretary of state for Texas, thanking him for his kindly services and the interest shown in Texas.

${ }^{3}$ F. O. Mexico, 134 .

Ibid.

${ }^{10}$ F. O. Mexico, 133 . 
Burnet stated further that both Treat at Mexico and Hamilton at London had full power to negotiate a treaty of peace, and that "any relative guarantee which you may feel it proper to offer to the Government of Mexico will be fully and faithfully ratified and redeemed by this Government."11

However authoritatively qualified, the post of Texan agent at Mexico was not an enviable one. The Mexican government was sure to present as many difficulties and hindrances as possible, and in particular to balk at any suggestion that carried with it an admission of Texan independence. At the same time Canedo and his fellow-ministers saw the wisdom of such an admission, and were deterred from advocating a policy that meant peace with Texas only by their fear of a popular uprising in the country. To steer the government so cautiously as to secure a permanent peace with Texas, without threatening the continuance of the government itself, called for skill and courage. Political opponents had only to appeal to so-called national pride in order to stir the people and overthrow the ministry. The whole situation was an open book to Pakenham, yet he had faith in the outcome, and on May I8 he wrote to Palmerston that the first step had been taken by laying the matter before the Council of State, with the idea of securing from Congress authority to come to an arrangement with Texas. ${ }^{12}$ Unfortunately, however, Treat had fallen dangerously ill, and even if he recovered it was probable that he would have to leave the country in order to recuperate. Treat's conspicuous ability in this truly

${ }^{11}$ F. O. Mexico, I35, March 12, 1840.
${ }^{12}$ F. O. Mexico, I35. 
difficult and delicate matter and his success in bringing the reluctant Mexican authorities to the point where they would at least consider Texan propos were gratefully appreciated by Pakenham. Havin previously doubted the successful issue of the negotia tion to the point of recognition, Pakenham, with Treat as intermediary, became distinctly sanguine.

Early in June, Can̂edo did in fact lay all the correspondence between himself, Treat, and Pakenham before the Council of State, and recommended that steps be taken to arrange a peace. The committee of the council to which Canedo's report was offered supported his recommendation, but the former secretary of foreign affairs, Gorostiza, opposed the report of the committee, obtained a majority of the council against it, and succeeded in putting through a resolution of his own which referred the whole matter to Congress, but with an emphatic disapproval on the part of the council " of any accommodation with Texas as an independent Country."13 This action was at first secret, but so many men were in the secret that rumors of it soon transpired, and the Chamber of Deputies demanded information as to what was going on. Thus forced, the government was obliged to lay the whole affair before Congress. At the moment that Pakenham wrote his account of these proceedings to the home government he still believed that the cabinet would carry its point, for he wrote that this specific attack would strengthen rather than weaken it in its original intention. ${ }^{14}$

${ }^{13}$ F. O. Mexico, 136, Pakenham to Palmerston, July 5, 1840.

${ }^{14}$ Ibid. Throughout all of this correspondence Pakenham indicates his disbelief in the permanence of the existing Mexi- 
The result of the public knowledge of the Treat megotiation was contrary to Pakenham's expectations. The government was not strengthened and did not fight but yielded to the public clamor. While Treat did not give up all hope, he did conclude that an armistice at least would be greatly to the advantage of Texas, if he could not get a definite treaty of peace. In August he informed Pakenham that he had received new instructions from his government authorizing him to treat for an armistice if a definite and permanent peace was not to be obtained, and that he might conclude a truce for one, two, or three years, if made terminable on six months' notice by either party. Pakenham was pleased with this new instruction from Texas, both because he felt it to be more reasonable in the existing situation, and also because it was directly in line with the advice which he himself had given. Treat was directed, however, to try first for some answer to the earlier proposals to which no reply had as yet been given by the Mexican government. Only in the case that Mexico ultimately refused the Texan peace proposals was Treat to present the idea of a truce. Treat therefore gave to Pakenham the Texan demand for

can government, and this somewhat weakens the force of his reports that the arrangement with Texas would go through. $\mathrm{He}$ is constantly speculating as to the possible overthrow of the government by the revolutionary federalist party or, which would seem preferable to him, by a slowly developing monarchical party. He even hints at the possibility that some Eurupean ruler will be placed upon the Mexican throne. Throughout the year 1840 his reports are full of the weakness and dishonesty of Mexican officials and of the Mexican government; and he compares its inherent weaknesses with the potential strength of Texas. 
46 THE NEGOTIATIONS OF TREAT AND HAMILTON.

an answer to its first proposals, with the request that he present it to the Mexican government. ${ }^{15}$

At the time when this arrangement was made and Pakenham had consented to act again as a go-between for Texas and Mexico, he was not quite sure of himself in his personal relation with the government of Mexico. Earlier in the year there had occurred in California the arrest of a number of American and English residents upon an accusation of conspiracy to overthrow the government at Monterey. Both Pakenham and the American minister had taken this matter up with energy, protesting vigorously against the illegality of the arrest, and demanding reparation. Some slight official friction had occurred in the summer of I840 over this incident, and considerable public excitement was shown. Mexico had been forced to acknowledge the error committed and to send orders for the release of the prisoners. The incident was comparatively unimportant in itself, but it hampered Pakenham somewhat in his rôle of peacemaker between the two governments. The answer of the Mexican government to Treat's demand for a reply was a refusal to enter into a negotiation. On September 2I, therefore, Treat presented a memorandum indicating his intention to withdraw since nothing could be got from Mexico. As usual, this went through the hands of Pakenham, and when presenting it, Pakenham, with Treat's consent, suggested that an armistice be concluded for a definite period. This, Pakenham wrote to Palmerston, was " a proposition which in the present state of this Country ought, I imagine, to be considered

${ }^{15}$ F. O. Mexico, I37, Pakenham to Palmerston, August 22, 1840 . 
by this Government as quite a Godsend."16 The government, however, appeared wholly indifferent, and several days elapsed before the matter was taken up at all. Treat naturally had insisted on the Rio Grande as the boundary line to be respected during the observance of the truce. To this Mexico definitely objected, and Pakenham being engaged at the moment upon a protest of his own regarding the Californian prisoners, there seemed no possible outcome for the tiresome negotiation. At Pakenham's urgent request, however, Treat agreed to wait one week longer.

The delay availed nothing. On October 26 Pakenham wrote that Treat's mission had definitely failed, that ever since October 7 he (Pakenham) had been busily urging the government to consider an armistice, but that the government had now finally declared that it could "entertain no proposal for an armistice which shall not be presented with the previous sanction of the Texian authorities," 17 the reason for this decision being the fear that the Texan government would not ratify an agreement, if one should be entered into. "And this," wrote Pakenham, " while there is actually a Texian Squadron cruising on the, coast, which may at any moment commence offensive operations, and the Mexican Government possess not a vessel of the smallest description, not even a boat, to oppose them."

The Mexican government added that even if an armistice were feasible, the line of separation between the two states must not be south of the River San

${ }^{18}$ F. O. Mexico, I38, Pakenham to Palmerston, October 7, I840.

${ }^{17}$ Ibid., Pakenham to Palmerston, October 26, 1840. 
Antonio. "With pretensions so irreconcilable and with so much obstinacy and infatuation on the part of the Government of Mexico, Your Lordship will not be surprised, and still less, I trust, attribute to any want of exertion on my part that nothing should have been effected."18

Pakenham was, in truth, bitterly disappointed that Treat's overture had resulted in failure. He felt that this failure might possibly be so construed as to reflect upon his own diplomatic ability, and that Palmerston, not understanding the shifting and uncertain quality of Mexican statecraft, would fail to give due credit for the energy he had displayed. Canedo, in his final note in reply to Pakenham's request for Treat's passport, harked back to the idea that Mexico would never enter into any negotiation having as its object the relinquishment of its sovereignty over Texas. The absurdity of this attitude, as Pakenham pointed out, was self-evident; the question of sovereignty was the real essence of the whole negotiation, and it had been freely discussed in the Mexican Council and actually submitted, finally, to the Chambers. Canedo's pretentious assertion, Pakenham wrote, "affords a fresh proof of the pusillanimous fear of responsibility and unpopularity which has influenced the conduct of the Mexican government throughout the whole af fair." A $^{\prime}$ successful conclusion of this negotiation would have been a decided feather in Pakenham's cap, and his natural disgust when he saw that there was to be no result in what had seemed a promising negotiation was therefore the greater. Canedo might have ${ }^{18} \mathrm{~F}$. O. Mexico, $\mathrm{I} 38$.

${ }^{19}$ Ibid. 
pressed an unpopular policy upon Mexico with greater promise of success if it had been possible for Pakenham to yield in the matter of the Californian prisoners. The California affair, however, should not be overestimated in its effect upon the Mexican public mind. It was but a small matter as compared with the question of the recognition of Texas. According to the evidence presented by the documents, Canedo was really ready to agree to an armistice looking toward ultimate recognition of Texas, but found more opposition than he had expected, and lacked the courage necessary to carry the affair through. Possibly, even if he had fought for it, he could not have carried it to a successful issue, and even as it was he was thought too acquiescent in his relation to Pakenham, and was accused by his political enemies of being the tool of England.

Treat left almost at once, Pakenham's kindly services assisting him in his journey. Before his departure he gave the British agent an authorized promise on the part of Texas that if hostilities were actively renewed, Texas would not seek to extend its territory beyond the Rio Grande. ${ }^{20} \mathrm{He}$ also promised to urge upon the government of Texas a policy of forbearance and peace, and in so doing was carrying out the policy favored by Pakenham. The latter, on his part, told Treat that he might " inform the Authorities of Texas that I consider my commission as Mediator as still open, and that I shall be at all times ready to communicate to the Mexican Government any pacific overtures which they may think proper to make." ${ }^{21} \mathrm{Un}$ -

${ }^{20}$ F. O. Mexico, 138 , enclosing Treat's note to Pakenham of October I4, I840.

${ }^{21}$ Ibid., Pakenham to Palmerston, December I9, 1840. 
50 THE NEGOTIATIONS OF TREAT AND HAMILTON.

fortunately, Treat could not carry to Texas these kindly offers, for he died on shipboard on the return journey.

Before the news of Treat's departure from Mexico could have reached England, Palmerston had addressed an instruction to Pakenham notifying him of the treaties signed with Hamilton at London in November. The explanation made of the reasons leading Great Britain to take these steps is based upon the inability of Mexico to reconquer Texas, and upon the necessity for the treaties in order to protect British commercial interests. In London itself there was but little intercourse between Murphy, the representative of Mexico, and Palmerston. ${ }^{22}$ All that appears for the year 1840 in the records of the foreign office is a protest from Murphy upon the British plan of recognizing Texas, and an answer from Palmerston giving the usual reasons for recognition and urging Mexico to change her views. ${ }^{23}$ In the closing month of the year Palmerston had some correspondence with a Mr. Robinson, who was acting as chairman of the British committee for the Spanish-American bondholders. In this correspondence Robinson asked the support of the government for a plan which the bondholders had agreed upon looking toward the location of twenty-five

${ }^{22}$ Murphy's activities in London seem to have been limited to a perfunctory performance of his official duties. He was at no time in close touch with British ministers, and in but one instance, to be noted later, did he show any energy. Possibly the frequency with which governments changed in Mexico hampered him. Certainly both Palmerston and Aberdeen preferred to deal with Mexican questions through the agency of British ministers in Mexico, rather than through Murphy.

${ }^{23}$ F. O. Mexico, I40, Domestic, Mr. Murphy. 
million acres of land in the territory now in dispute between Mexico and Texas. Robinson recited that by an act of Mexico in 1837 . it had been provided that security for that portion of the Mexican debt called "deferred stock" should be offered to the English bondholders in the shape of one hundred million acres, located in various provinces of the Mexican Republic. The act had promised that of these lands, twenty-five million acres should be located "in the departments having the nearest communication with the Atlantic, and which may appear best suited for colonization from abroad." ${ }^{24}$ Hence, the committee now urged the location of this portion of land in the disputed territory, and the benefits to Mexico, to Texas, and to the bondholders were all stated at length, while advantage to the British government, it was urged, would result if such an arrangement should "lead to the introduction of British settlers in Texas and to a consequent further strengthening of British interests in that quarter."25 This proposal was the result of the suggestions originating with Gordon, at New Orleans, and represents the interest taken in the matter in London. The hand of Lizardi and Company does not appear in this proposal when brought up in London, but unquestionably this was but a part of the scheme originated by them. The proposal itself should be regarded merely as an effort on the part of the bondholders to recover some part of the principal long before advanced to Mexico, and it cannot be counted as a weighty reason in inducing Palmerston to recognize

${ }^{24}$ F. O. Mexico, I42, Dom. Var., Robinson to Palmerston, November 30, 1840 .

${ }^{2}$ Ibid. 
Texas. Palmerston was in favor of the scheme in general, and instructed Pakenham to give it a friendly countenance and support, and to employ his "good offices with the Mexican Government in furtherance of the views of the Bondholders."26 Having determined upon recognition, however, Palmerston naturally welcomed an opportunity to benefit English merchants where he could do so legitimately.

It now becomes necessary to look into transactions at the London end in the midyear of 1840. By July, Palmerston's mind was made up to recognize Texas. At that time he had been apprised of the correspondence between Hamilton and Pakenham and of Treat's arrival in Mexico, but of the reception accorded Treat's plan by the Mexican government he knew nothing. Soon after reaching London, Hamilton had had a short interview with Palmerston, and he then proceeded to the Continent to take up the matter of securing purchasers for Texan bonds. Late in July he wrote to Texas that he was sure that England was preparing to sign treaties, and that upon his return to England no great delay would be experienced. He returned to London in September, but it was not until the middle of October that Palmerston was ready to consider seriously a definite treaty arrangement. On October I4 Hamilton wrote to Palmerston that he was authorized to sign a treaty of commerce and navigation if Great Britain would recognize Texan independence, and he transmitted with this letter a communication outlining the arguments which he hoped would win his case. This document is worth quoting

${ }^{26} \mathrm{~F}$. O. Mexico, I33, Palmerston to Pakenham, December I5, I840, with copies of the correspondence with Robinson. 
in full, as illustrating both Hamilton's method and the arguments which he believed would appeal to Palmerston.

Reasons why Great Britain ought to recognize the Independence of Texas \& form a treaty with her.

Ist. The future \& rapidly increasing value of the Trade with Texas, under a judicious commercial Convention.

2nd. By this means she secures a great Cotton producer and important consumer of her Manufactures, as her customer \& a friendly neutral in the event of a war with the United States-

3rd. The Recognition of Texas by Great Britain inevitably Superinduces peace between Mexico \& Texas.

4th. Peace at this moment between Mexico \& Texas will inevitably insure the payment of a portion of the Mexican debt by Texas.

5th. It likewise insures under the friendly mediation of England a permanent Boundary Line between Mexico \& Texas, which will be inviolably observed by Texas, \& repress the spirit of future conquest on the part of the Anglo-American race-

In case England does not recognize the following consequences are likely to follow-

Ist. In sixty days from this day Vera Cruz, Tampico \& Matamoras will be blocaded by the Texian Squadron, which consists of one Corvette, two Brigs, three Schooners \& one naval Steamer, now off the Coast of Mexico, while Mexico is destitute of all naval force whatsoever.

2nd. If Texas is informed that Great Britain will not recognize her Independence \& that consequently there is no hope of peace with Mexico, she will forthwith join the Federalists, revolutionize the northern provinces of Mexico \& make such additions to her Territory as the laws of war would justify under the usages of civilized nations.

3 rd. Great Britain has an obvious interest in avoiding a discriminating duty which will be levied against the productions of all nations which have not recognized Texas \& formed Commercial Treaties with her on or before the Ist of Feby. next.

4th. If Her Majesty's Government should decline recognizing I must avail myself of the present situation of public affairs in Europe \& make the most beneficial arrangement I 
can with some continental nation giving it exclusive commercial advantages for a valuable equivalent.

5th. Texas greatly prefers a friendly alliance with England from all those considerations which are connected with a common origin-But if Great Britain refuses all international companionship with her, she will be driven to seek friendly \& profitable associations elsewhere.

Respectfully submitted

J. HAMilton. ${ }^{27}$

It may well be doubted whether the arguments here advanced by Hamilton would have appealed to a man of more cautious temperament than Palmerston. They were, however, particularly well suited to a man of his type of mind and boldness of conception. After a number of succeeding interviews, Palmerston, on October I8, wrote to Hamilton that Great Britain was ready to negotiate the desired treaty if Texas would at the same time sign a slave-trade treaty giving to Great Britain the right of search. He stated that this would be "a sine qua non Condition of any other Treaty between Great Britain and Texas," 28 but he was careful to explain that this right of search differed from that which Great Britain had exercised in former times, and that it was very necessary if the African slave-trade were to be suppressed. The unusual length of Palmerston's explanation and the care taken by him in minimizing the actual operation of the right of search furnish evidence of his anxiety to conclude the other treaties with Texas and to recognize that State. ${ }^{29}$ Apparently Hamilton offered no

${ }^{27}$ F. O. Texas, $\mathrm{r}$.

${ }^{28}$ Ibid.

${ }^{20}$ Ibid. All of the correspondence between Palmerston and Hamilton is to be found in this volume. 
objection to a slave-trade treaty, stating his approval on October 22.

Palmerston's insistence upon a treaty looking toward the suppression of the African slave-trade was due to a variety of causes, some of them based upon the traditional policy of Great Britain, some arising from conditions peculiar to the summer of 1840. Great Britain had been for a long period earnestly attempting to suppress the slave-trade. Her initial efforts had not been supported by the other European powers, but after I830 a series of treaties had been signed with various European states by which a reciprocal right of search was given, as a result of which the slave-traders had been deprived of the protection of European flags. It was, therefore, only a customary policy to insist upon signing a slave-trade treaty wherever it was thought possible to secure it. After 1835, however, British public interest in regard to the slave-trade had been less acute, and for that reason less pressure was ordinarily brought to bear upon the government in this connection than formerly. In 1840 interest in the slave-trade was revived in Great Britain, and several vigorous abolition speakers from America came to England to help in spreading this revival. Buxton, one of the most prominent of the English abolitionist leaders, had brought about the organization of a society which was known as the "African Colonization Society," having for its purpose the establishment of British colonies along the Guinea coast. These were intended to prevent the egress of slaves from the interior of Africa, and so to break the line of connection between the native chiefs who sold slaves and the 
traders who purchased them. Also of indirect assistance to the abolition cause was the mission of a certain Mr. R. R. Gurley, secretary of the American Colonization Society, whose object in England was, nominally, to secure support for the American project of colonizing free blacks in the State of Liberia, and actually to counteract the influence of northern abolitionists in Great Britain. So far as his cause was concerned his mission was a complete failure. It resulted rather in stirring up a more intense feeling among English abolitionists and contributing to the revival of interest in the suppression of the slave-trade..$^{30}$

How far Palmerston was affected by this abolition discussion and excitement there is no record. Letters bearing on the slavery question came to him from both sides. Previous to the signing of the Texan treaties he had received from private and from official sources information as to slave conditions in the territory, together with advice as to England's advantages in the event of Texan independence. Thus, a Mr. Nicholas Maillard had written on September 15, pro-

${ }^{30}$ Gurley, Mission to England in Behalf of the American Colonization Society. Washington, 184r. He arrived in England in July of 1840. The object of Gurley's trip to England was very largely to prevent, if possible, any influence from Buxton's book and society. Gurley saw in Buxton's plan a scheme to cripple Liberia. He so far failed in his plan, and aroused so much feeling, that the executive committee of the American Colonization Society recalled him, and later accepted his resignation. His book is a general defense of his acts in England, but it serves to emphasize the break which had come at this time in the former friendly relations of the American Colonization Society and abolition circles in England. Gurley also brings out clearly the renewed strength, in the summer of 1840 , of the abolition movement. 
testing against English recognition of Texas, and basing his protest largely upon the existence of slavery within that State. ${ }^{31}$ On the other hand, a letter from Captain Hamilton of the British navy, written from Barbados in June of 1840 , urged a speedy recognition of Texas, and another letter from one Sheridan was transmitted by Sir John McGregor, governor of Barbados, which outlined his ideas upon the same subject. ${ }^{32}$ Sheridan's letter was very long and was characterized by its comprehensiveness, its occasional picturesqueness, and its judicial tone in exhibiting an effort to balance the pros and cons of the Texan situation. $\mathrm{He}$ was thoroughly awake to the notorious defects of character in Texan citizens. They were, he wrote, "principally Bankrupts, Swindlers and Felons from the United States, occasionally diversified with an Oasis of respectability which only renders the Desert of Villainy around more conspicuous by contrast." The bowie-knife, which he described at length, was "the ordinary weapon of defence," Texan finances were in a desperate state, and the public services were inade-

${ }^{\text {a1 }}$ F. O. Mexico, I42. "The Government of the United States, have commenced pouring supplies into Texas, in order that she may be able to fulfill her engagements with the Federalists, and if Texas only gets sufficient slave labour to develop her resources, the Federalists must succeed eventually, when we shall see Slavery revived and perpetuated, and other Institutions still more injurious to our Interests, and repugnant to our National principles, established throughout Mexico, whose dismemberment at this or any future period must prove most ruinous to British Interests in that quarter." Maillard was the author of a work on Texas, written to arouse sympathy with Mexico in her efforts to reconquer that province.

${ }^{x}$ F. O. Mexico, I42, Dom. Var. 


\section{THE NEGOTIATIONS OF TREAT AND HAMILTON.}

quately paid, except those of the members of Congress, who, "in consideration of their Gigantic labors, and the risk they run of being bowie-knived during debate (a custom of by no means rare occurrence)," received fairly reasonable salaries. But when he turned from a narration of events and conditions to the rôle of advocate and prophet, he became most enthusiastic, and acknowledged that the political leaders of the State were men of "talent, worth, and respectability." He urged that should England promptly recognize Texas, it would be quite possible to check the growth of slavery in the State, and ultimately to see it eradicated. He went even further and asserted that if Great Britain desired to make it a sine qua non that slavery be abolished, Texas would consent, if not to immediate abolition, at least to a scheme of apprentice emancipation. In conclusion, he spoke of the perfectly explainable anger of Texas at the refusal of the United States to annex, and dwelt upon the great commercial interest of England in developing that State as a place for the supply of raw cotton independent of United States influence. He believed "that twenty years would not pass away before England (if necessary), might exclude every bale of cotton made in the States."

From such letters as the preceding, Palmerston gathered general information as to Texan conditions at the time he signed the treaties. These treaties were three in number. The first, signed on November I3, was a treaty of commerce and navigation. Its provisions were similar to those commonly inserted in any treaty providing for commerce between two countries. 
The second treaty, signed on November 14, was in form a "Convention containing Arrangements relative to the Publick Debt." 33 It recited that Great Britain had offered her mediation between Texas and Mexico, that Texas had accepted that offer, and that in case a successful mediation with Mexico was accomplished within six months after the convention was communicated to the Mexican government and a treaty of peace signed, Texas would assume one million pounds sterling of the foreign debt contracted by Mexico before January 3I, I835. The third treaty, for the suppression of the African slave-trade, was signed on November 16 , and provided for a mutual right of search by a certain limited number of cruisers of each nation, with the further limitation that such right of search could be exercised only when specific warrants had been issued to the commanders of the cruisers indicated. ${ }^{34}$

These treaties were to be ratified within six months, and upon such ratification British recognition of Texan independence would, in fact, be assured. It is apparent that Palmerston believed that there existed no immediate danger of an American annexation of Texas, and that Texas herself desired independence of the United States. This belief is in part traceable to Hamilton's arguments. On the other hand, in regard to the question of the slave-trade, there was in Palmerston's mind at this particular moment a desire to bring pressure upon the United States in order to secure from that government at leașt a limited right of search.

${ }^{23}$ Sessional Papers, 1842, Commons, Vol. 45, for texts of first and second treaties.

${ }^{34}$ Sessional Papers, I842, Lords, Vol. II. 
60 THE NEGOTIATIONS OF TREAT AND HAMILTON.

Throughout the two preceding years the abuse of the American flag by the slave-traders had been steadily increasing, as had also the irritation felt in America at British interference with vessels sailing under it. The matter was approaching a crisis, and Palmerston unquestionably hoped to use this slave-trade treaty with Texas as an example of what the American government ought to be willing to concede. The recognition of Texas by Palmerston was, therefore, a result of a variety of motives, none of them in any sense reflecting upon the diplomacy or the motives of the British nation, and all of them perfectly compatible with a friendly yet open rivalry with the United States for a controlling influence in the Gulf of Mexico. 
month and in February the newspapers were filled with indefinite charges and vague threats, all, apparently, directed against the English government, and betraying the sense of outraged national pride and that romantic patriotic bluster which was the country's striking characteristic as it was its greatest misfortune. This false patriotism, to which Pakenham had already called attention, violently demanded that Texas should be reconquered, but Pakenham noted that the government took no steps toward attacking the revolted province. Occasionally the government resorted to petty methods as an expression of Mexico's irritation with England. As an instance of this, Pakenham found the French flag in the place of honor at an official ball in March, with the British flag next below. Considering his country to be insulted, Pakenham felt called upon to protest, and he demanded that the British flag be placed above that of France, adding, however, that he would not object if the United States flag were placed above those of all other countries, since the United States had been the first government to recognize Mexico. The officials present at the ball disclaimed any responsibility for the arrangement as it existed, but finally traced the matter to a French "artiste" who had had charge of the decorations. They refused, however, to make the change demanded by Pakenham, and that gentleman went up into a gallery, himself took down the British flag, and with it in his care left the ball, followed by all the English residents. Relatively unimportant, though reported by Pakenham in a serious vein, ${ }^{2}$ this

${ }^{2}$ F. O. Mexico, I44, Pakenham to Palmerston, March 26, I84I. 
incident serves to show the temper of the British representative at Mexico and something of the arrogant treatment to which this much harrassed government was obliged to submit from British ministers.

The flag affair was only another irritant to Mexico, and in May more newspaper articles appeared, criticizing the treaties between England and Texas. In one of these the exact language of a confidential note which Pakenham had addressed to the government on March II was repeated. The article in question met the armistice proposals of Pakenham's note, but asserted that the great underlying purpose of England in the Texas negotiation was not to aid Mexico but to check United States expansion; that Mexico, in English policy, was but a catspaw to be used at any moment when it suited English interests. There was, further, a sneering allusion to Great Britain's professed anxiety for the extinction of slavery, while she prepared to recognize Texas without referring to that institution. The article did not indicate that Pakenham was the author of the proposals credited to England, but the use of his note naturally convinced him that responsibility for the publication must lie with some one high in authority in the Mexican government. He protested against such use of his diplomatic correspondence, but secured no satisfaction from the minister of foreign affairs. ${ }^{3}$

$\mathrm{Up}$ to the middle of June, Pakenham had not as yet made any formal presentation of the plan outlined in the second of the British-Texan treaties, signed November I4, I840, looking toward a mediation between

${ }^{8}$ F. O. Mexico, I45, Pakenham to Palmerston, June Io, I84I. 
Texas and Mexico. Without direct instructions from Palmerston to bring this matter up formally, he had not thought the time ripe for its presentation. The Texan government, however, had sent the then Texan secretary of state, Judge Webb, to Mexico for the purpose of proposing directly to Mexico terms in accordance with the treaty signed at London. Webb was refused permission to land at Vera Cruz, and sent his documents and proposals to Pakenham, asking his aid in getting a hearing. This was on June I. Pakenham did all in his power to assist in the matter, and sent a note to Camacho, the foreign secretary, stating the object of Webb's mission, and urging a hearing for him. Both by note and in a personal meeting with Camacho he expressed again Great Britain's desire for peace between the countries, but in spite of his best efforts and all his arguments, he could get no concession.

Camacho, in his reply to Pakenham's communication in Webb's behalf, did not limit himself to a mere refusal, but attempted a reproof of what he considered British hypocrisy in the recognition of Texas. "Mr. Pakenham cannot but be aware that ever since the insurrection of the Department of Texas they have been introducing and still are introducing into it, innumerable slaves; a traffic which shocks humanity; which reason alone, even were there none other, would ever prevent the Mexican Republic and her Government from lending themselves to an act amounting to a sanction and acknowledgment of Slavery." "

Admitting his present failure, it only remained for

‘F. O. Mexico, 145, Pakenham to Palmerston, June Io, I84I. 
Pakenham to notify Webb of the purport of the Mexican answer, and suggest that until there should be an official communication to Mexico of England's action, there would be little hope of getting anything done. As in the case of Treat, he again urged a pacific policy for Texas, and assured Webb that he still regarded himself as a mediator for that State.

Pakenham reported the entire matter to Palmerston on June 10, ${ }^{5}$ and stated that he had no hope of securing peace "as long as the Government of Mexico remained in the hands of the present rulers." A change of government was indeed imminent, and the air was full of rumors as to the time and occasion of the revolution that all felt was inevitable. Such a change seemed very desirable to Pakenham. He wrote, "The conduct of the present Government of Mexico has lately been such as thoroughly to disgust every well thinking person and every well wisher to this Country." " The long-expected revolution which placed Santa Anna again in authority followed. ${ }^{7}$ Pakenham's

${ }^{5}$ F. O. Mexico, 145 .

'Ibid. At this time it became Pakenham's duty, in response to instructions from England, to remind the Mexican government of a number of British claims, and to demand some sort of promise to English merchants. Many of these claims had been acknowledged by Mexico, but payment had been indefinitely postponed, and having his attention again called to the matter, Palmerston, in 184I, turned the affair over to Pakenham, who made a general representation, and so reported. F. O. Mexico, 146, Pakenham to Palmerston, August 30, $184 \mathrm{I}$.

"Antonio Lopez de Santa Anna was born in I795 and died in 1876. The "grey wolf" of Mexico, he is usually regarded as having been an evil influence in his country; always an intriguer and revolutionist, ambitious for power, at heart a 
description of its causes emphasizes the general dissatisfaction on the part of Mexico with the high protective policy of its government, with the heavy tariffs on foreign goods, and with the duties levied on international trade. It does not specify the antiforeign sentiment of the previous year as contributary to the causes of the revolution, and it thus appears that Pakenham's information as to ultimate causes had come from the members of the new government. Indeed, he was now quite hopeful that, under Santa Anna, Mexico would secure a more centralized and powerful government.

While there can be no question that Mexico was always deeply concerned at the loss of Texas, and was anxious to find some honorable outcome of a difficult situation, the records of I84I show plainly that during that year at least, other questions conspired to push into the background her relations with Texas. For the moment, indeed, Mexican protests and Mexican policy centered upon the domestic situation, and while indignation might be expressed at the readiness of England to recognize Texan independence, this was rather intended for the public ear than as a key to future policy. Nevertheless, from the increased pressure brought upon the English government by British

genuine despot, he advocated now this course, now that. $\mathrm{He}$ was president in 1832 and again in 1835 , when his establishment of centralism in place of federalism gave to Texas the excuse for revolution. Captured in the attack on Texas, he was sent to Washington, and on his return to Mexico found his popularity gone; but his defence of Vera Cruz against the French in 1838 brought him to the front again, and on October Io, $184 \mathrm{I}$, he became provisional president and remained in power until December, I844. 
merchants regarding their claims upon Mexico it is quite clear that those merchants were aware of the Mexican unrest and were fearful that the Mexican state was about to fall to pieces. The merchants secured but scant satisfaction from Palmerston. When, in the autumn of I84I, Aberdeen replaced him after the fall of the Melbourne ministry, a number of letters addressed to the foreign office accused Palmerston of negligence, and urged upon Aberdeen an honorable support of British interests. He adhered, however, to the policy of his predecessor, and simply repeated the instructions previously given by Palmerston, calling the attention of the Mexican government to the claims of British citizens.

At London as well as at Mexico conditions were unfavorable to a continuance of Texan negotiations on the lines started and for the objects sought by $\mathrm{Pal}$ merston. The treaties signed by Hamilton were not yet ratified, and it soon appeared that Hamilton had sent the first and second treaties by one messenger, while entrusting the slave-trade treaty to another. It thus resulted that the Texan legislature sanctioned the treaties of commerce and of mediation with no apparent knowledge of the treaty for the suppression of the slave-trade. That treaty did not reach Texas until after the adjournment of the legislature. Under the circumstances Palmerston refused to ratify the other treaties, and, in order that they might not fall to the ground, arranged to postpone the date for the exchange of ratifications. Hamilton's questionable proceedings in connection with this matter subjected him, both then and later, to suspicions as to his motives, and 
these suspicions were undoubtedly well founded. $\mathrm{He}$ had in fact been given no authority to negotiate a slavetrade treaty, and he may well have hesitated to send it to Texas. Having failed to hurry Palmerston into a ratification of the first and second treaties, Hamilton renewed his efforts when Aberdeen came into office, urging in excuse for the non-arrival of the slave-trade treaty previous to the adjournment of the Texan legislature that he had entrusted it to a man (not named) especially well qualified to press it upon Texas, but that this man had fallen ill in New York, and had not reached Texas until too late. The affair certainly had the appearance of a cheap trick or ruse, though it is difficult to believe that Hamilton really expected that the British government would exchange ratifications for only two of these treaties when all three were necessary to carry out the plan agreed upon. He actually urged this, however, and when both Palmerston and Aberdeen had refused, had the temerity (as will be noted later) to propose still another treaty, as a necessary inducement in order to persuade Texas to ratify that upon the slave-trade. ${ }^{8}$

In the meantime, Melbourne's government found itself in such difficulties that no attention could be given to Texan treaties, and during the summer of r84I it was evident that a change of administration must soon take place. The government was in fact discredited in all directions, having failed in details of home policy, and having gradually alienated most of its friendly allies upon the continent of Europe by the foreign policy pursued in relation to Egypt and Turkey. In spite of a series of defeats upon minor

'F. O. Texas, 2, Hamilton to Aberdeen, September II, I84I. 
questions, Melbourne and his colleagues still clung to office, and the change did not come until August 30 . In the new government Peel became prime minister, and Aberdeen took Palmerston's place at the foreign office. For three months the fall of the ministry had appeared inevitable to the English public, and it was not strange that Hamilton had found it impossible in the last few months to secure from Palmerston any attention to Texan affairs. He at once appeared before Aberdeen with renewed hope and fresh devices, to present the old arguments in some new form and to urge still another treaty upon the English government. This project, as Hamilton sketched it, had for its object the establishment of such close trade relations between Great Britain and Texas as, if adopted, would give to the former a decided preference over all other nations in Texan trade. Great Britain was to pay but one half the amount of import duty levied on similar articles from other states. Other special privileges were mentioned, among them the right of Great Britain to a free purchase of ship timber from the Texan forests, a point upon which Hamilton laid much stress. On the other hand, Texan interests were to be secured by a British guarantee of the bonds of the Republic of Texas, for which Texas would pledge "her Revenues, Customs, Taxes and the proceeds generally of the Sales of her public Lands." In addition to the commercial advantages to England and her guarantee of a Texan loan, which are here introduced for the first time, other provisions of the treaty called for the assumption by Texas of one million pounds of the Mexican debt as the price of recognition, and also provided for the location of lands in Texas in favor of Mexican bondholders. 
In pointing out the advantages of this arrangement, Hamilton repeated many of the arguments previously presented to Palmerston, but placed more emphasis than formerly upon the danger of an American annexation of Texas and the necessity of prompt action to avert this. He painted in glowing colors England's advantage in having a constant source of cotton supply outside of the United States, and appealed to British jealousy of the United States and British fear of an attack upon Canada by that country. Texas independent would be, he said, both an ally of England against the United States as regards Canada and an efficient barrier against American ambitions in the direction of Mexico. With arguments carefully balanced and stated to appeal to national jealousy, pride, and commercial advantages, there was still no discussion of the slavery question. There was no concession that Texas might ultimately abolish slavery, yet Hamilton had the effrontery to urge that a great philanthropic object was to be attained, since this treaty giving a British guarantee to Texan bonds would probably secure from Texas the immediate ratification of the slave-trade treaty. It is quite possible that Hamilton's object in delaying the transmission of that treaty was to use it in securing the adoption of this new convention, ${ }^{9}$ for in all his efforts Hamilton was as much interested in securing financial support for Texas as in

'F. O. Texas, 2. Several letters from Hamilton to Aberdeen refer to this matter, but the project itself and Hamilton's argument in support of it exist in the form of copies preserved by the foreign office, for Hamilton asked that both the project and his argument be kept a secret from all save the members of the English cabinet, and that his documents be returned to him. 
obtaining recognition. He was a good financial agent but a poor diplomat, at least in England, where good faith was essential.

On October 4 Aberdeen finally replied, refusing to take up the matter and insisting that the three treaties already signed were all that Great Britain would negotiate for the present. Though definitely declining to discuss further treaty arrangements, Aberdeen considered Hamilton's projects of sufficient importance to present them to the other members of the cabinet. The opinion of one expert adviser in such matters, Henry Goulburn, then chancellor of the exchequer, is on record, and practically embodies the foreign secretary's policy of the next few months in the Texan matter. ${ }^{10}$ Goulburn's advice assumed that it was essentially the purpose of Great Britain to preserve friendly relations with the United States and to avoid any appearance of conflict with American interests. Aberdeen's official acts were quite in harmony with the points made, as was his intention, expressed a little later, of sending a man to America with power to negotiate on all matters of dispute between the two countries, with the hope that all difficulties might be amicably adjusted. The greater portion of Goulburn's letter is devoted to an analysis of the finances of Hamilton's scheme, of which he distinctly disapproved. With reference to the feeling which might be engendered in the United States, he wrote:-

If this [trade preference] can be done what will be the feeling of the United States at being excluded from the supply of a Country peopled mostly by her own subjects and governed by a constitution framed on the model of that of the U. S.

${ }^{10}$ F. O. Texas, 2, Goulburn to Aberdeen, October I, I84I. 
Will it not engender a feeling of animosity towards us and strengthen that party in America who are labouring to exclude our manufactures from the markets of the United States who are now without doubt our best customers. And will not this feeling be aggravated by the idea put forth by General Hamilton that Texas is to furnish us all the Cotton and Tobacco that Great Britain can require.

There was no reason to believe that Aberdeen's succession to the ministerial post would mean any radical change in policy. If Goulburn's opinion was representative of the ministry and of Aberdeen, their official action was to be determined by caution and deliberation. Palmerston had prepared to recognize Texas when the ratification of treaties should be exchanged, and for the present Aberdeen was content to take matters as he found them. Also there were other questions of more immediate importance to claim his attention, and he was as yet unfamiliar with the situation in Texas. As there was still no evidence that Texas intended to renew her offer to the United States, there was of course no excuse for haste in preparing measures to prevent American annexation.

Shortly after Hamilton's project had been declined, Aberdeen received from a Mr. William Kennedy several letters which exhibited much knowledge of Texan affairs and offered the writer's services for the furtherance of British interests. Kennedy was a young man of education, who had gone with Lord Durham to Canada in 1838 . When Durham resigned, Kennedy traveled through the United States and into Texas, spending a large part of 1839 there. He was popular with the Texans, was well treated by them and was very favorably impressed by the new State. As a re- 
sult of his sojourn he published in $\mathrm{I} 84 \mathrm{I}^{11}$ a two-volume work on the past and future of that commonwealth. Kennedy's presentation of the case for Texas does not concern itself with sentimental or moral issues. His examination into the matter of annexation is a question of statecraft argued on the basis of national power and commercial advantages. Great Britain's present opportunity was twofold: to extend relations and to check American expansion to the southwest. $\mathrm{He}$ asserted very positively in his work that the antislavery sentiment in the United States was not the only hindrance to the American annexation of Texas, but that the high-tariff faction in the North opposed it, and that Texas herself would necessarily have to adopt free-trade principles. Thus might Texas become, in the hands of England, a weapon to break down the protective policy of America. Yet in most matters Kennedy wrote in a very fair spirit with regard to America, and with keen analysis of conditions as he saw them. His book attracted much attention in London, for it was the first one issued there upon Texas, was so well written as to be certain to exercise influence, and was full of exact and detailed information.

Kennedy, then, having produced his book, and having already been recommended by Hamilton to Palmerston's attention, offered his services to Aberdeen. His first proposal was that the government should pay his expenses to Texas to secure the ratification of the unlucky slave-trade treaty. Kennedy's popularity in Texas was so great, he assured Aberdeen, that he

${ }^{11}$ William Kennedy, Esq. Texas: The Rise, Progress, and Prospects of the Republic of Texas. Two volumes, London, I84r. 
would have little difficulty in accomplishing this. ${ }^{12}$ Receiving no reply to this letter, he wrote again on October 20, stating his most recent intelligence from Texas, the probability of the election of Houston as president, and the necessity that some English agent should get in touch with the new officials of the Texan government. He urged that England must be active, and said, "A new revolution has broken out in Mexico - military associations for the purpose of overthrowing British rule and influence in North America have been formed, from Mexico to Missouri,-the planters of Cuba are growing impatient of British interference in the Slave Trade." He was "thoroughly convinced that, unless English influence be employed in raising up a stable independent power in the South-Western, and North-Western frontiers of the Union, a very few years will suffice to place the whole of the territory they covet under the Sovereignty of the United States. - There lies the danger to the Maritime and Commercial supremacy of Great Britain." Even this vivid prophecy of a menace to British power brought no answer from Aberdeen, and on November 6 Kennedy wrote again; he referred to the slavery question, and predicted that it would not be difficult to secure the abolition of slavery in that State if England would help Texas and said that he (Kennedy) could be useful in this cause. Finally, on November 8, Aberdeen appointed an hour for an interview, and within a few days Kennedy had received some sort of a commission to go to Texas and report upon affairs there for the benefit of the British government.

The exact nature of Kennedy's mission is not evi${ }^{12}$ F. O. Texas, 2, Kennedy to Aberdeen, October 12, I84I. 
dent from the correspondence between Kennedy and Aberdeen, either at this time or later. His letters are merely reports, and do not indicate that he had authority to act in any official capacity. However, the ratification of the slave-trade treaty was finally secured during his residence in Texas, and Kennedy appropriated to himself much credit for it, and emphasized his personal intimacy with Texan officials. With how much justice he assumed the possession of such influence it is impossible to say, for the ideas and suggestions of an agent may not necessarily be those of his chief. The agent's proposal does not in the least involve his chief's acceptance of a policy. Nevertheless, the selection of Kennedy to go to Texas and report existing political conditions throws some light upon Aberdeen's attitude. He certainly knew Kennedy's book, and the opinions expressed in it must have appealed to him in some degree, or he would not have selected its author as his first agent to be sent to Texas. Kennedy's letter of November I 3 to Aberdeen showed that his instructions were general in scope, but that they at least required his arrival in Texas before the adjournment of the Texan legislature. The only possible object in this was the opportunity for Kennedy to use his personal influence with the legislature to bring about the ratification of the slave-trade treaty. Meanwhile, until the treaties were ratified, the man who was to occupy the principal diplomatic post in Texas, Captain Charles Elliot, could not be sent there, and was still detained in London. ${ }^{13}$

${ }^{13} \mathrm{~F}$. O. Texas, 3, Palmerston to Elliot, August 4, I84r. Elliot received notification of his appointment as chargé d'affaires at this time. The nomination was then made, but it was not until the summer of 1842 that Elliot finally went to Texas. 
Kennedy left London in November of I84I. He wrote four letters from America, and one upon his return to England. ${ }^{14}$ Before he reached Texas on his tour of investigation a change of administration had taken place; Houston had succeeded Lamar as president of the Republic, and Anson Jones was made secretary of state. Kennedy's letter from Galveston, January 10,1842 , merely reported the general financial depression prevalent throughout the United States, and explained that this very depression had been favorable to Texas because of the increased immigration there. He argued that any idea of Mexican reconquest was folly, and he urged the necessity of prompt action by Great Britain to secure the friendship of Texas in order to thwart what was undoubtedly a tendency of the moment toward annexation. He believed that the ratification of the slave-trade treaty had been delayed at the specific request of Hamilton, but for what reason is not stated. On January 28 Kennedy wrote from Austin that Congress was in session, and that he had succeeded in acquiring a great influence with its members. He again asserted that Hamilton was the cause of the delay in the ratification of the slave-trade treaty, and that it was only after he (Kennedy) had urged immediate ratification that it was secured and the favorable vote taken on January 22. He urged that England go so far, if necessary, as to force Mexico to make peace, and that quickly, and he en-

${ }^{14}$ The first of these letters was dated December Io, from New York; the second, January Io, from Galveston; the third, January 28, from Austin; the fourth, March 8, from New Orleans. They appear in F. O. Texas, 3. There is a fifth letter in F. O. Mexico, 158, Dom. Var., after his return to England. 
closed a personal letter from Houston desiring Kennedy to inform the British minister that Hamilton alone was responsible for the earlier failure to ratify the slave-trade treaty. Kennedy reported later that Hamilton had been dismissed in disgrace. If Aberdeen believed all of Kennedy's report, he understood that Hamilton was utterly discredited in Texas.

After a tour in western Texas, Kennedy reached New Orleans in March, and from there went directly to England. It is perfectly clear from his letters that whatever his instructions were, he imposed himself upon the people at Austin as a representative of the British government, and stated that the policy which he urged upon the Texan government was such as would be sanctioned by Aberdeen. There is no evidence that he was authorized to take this stand, but on the other hand there was no reproof administered by Aberdeen. His last letter was written after landing in Liverpool on April 20. In it he vaunts his own influence in thwarting an annexation scheme in Texas: "I do not think I arrogate too much to myself in saying that the confidence reposed in me by the Government and people of Texas materially contributed to allay the excitement in favor of an immediate annexation to the United States. . . . I obtained, at all events, a suspension of the question until the dispositions of Great Britain could be known." ${ }^{15}$ Very soon after

${ }^{16} \mathrm{~F}$. O. Mexico, 158 , Dom. Var. In the same volume appears a letter from Hamilton to Aberdeen, March 25, 1842, written from Charleston, South Carolina. In this, Hamilton makes a vigorous complaint of Kennedy, and charges him with having spread false reports as to his (Hamilton's) activity in London. Houston is attacked viciously also. The tone of the letter shows an extreme anger which must have 
his return to England, Kennedy accepted an appointment from the Texan government as consul-general in London, but he held this for a short time only, resigning to accept the position of British consul at Galveston.

As to Aberdeen's action in selecting Kennedy as his emissary at this time, it is a safe conclusion that he was sent over to Texas to gather useful information for England from all available sources. It is obvious that accurate information upon public or official matters would be more accessible to a man who knew the country and was popular with the people than to a stranger. Possibly, too, Kennedy's influence may have been counted on as of some assistance toward the ratification of the slave-trade treaty. But that Aberdeen's policy at this time proposed British assistance toward the up-building of the Texan State or British pressure upon Mexico is most unlikely. It is improbable that Kennedy's mission signified a deeper purpose than appeared upon its face, and the logical conclusion must be that his comprehensive reports were rather to contribute toward determining a policy than to further one already agreed upon.

injured Hamilton in the estimate of Aberdeen. There is a letter also from Hamilton to Kennedy, written on March 4 from New Orleans, full of insults to Kennedy, and with a virtual challenge to fight a duel. 


\section{CHAPTER IV.}

i842, January to June. The Montezuma and the GUADALOUPE.

The year I842 marks the development of a definite British foreign policy with regard to Texas, though the earlier months of that year show Aberdeen treading uncertainly in the path of his predecessor. Under Palmerston, Great Britain favored an independent Texas, openly, and occasionally at some risk to English-Mexican relations. Presuming to dictate to Mexico, unsympathetic with its people, and lacking confidence in its government and future, Palmerston boldly embraced a policy which looked to the strengthening of the Texan State. Supported by Pakenham, whose enthusiasm and confidence regarding Texas were unbounded, and believing in the people and the development and power of that State, Palmerston had been the more easily brought to a line of action which incidentally served to stimulate resistance to United States expansion.

Aberdeen, on the other hand, was slow to find himself, anxious to be just, and desirous of avoiding any rupture with Mexico. He determined eventually on a line of policy differing, to be sure, from Palmerston's in inspiration and motive, but somewhat resembling it in operation and effect. While each minister desired to preserve friendly relations with both states where possible, Aberdeen's policy was essentially and characteristically conservative, and showed a desire to see 
Mexico resume here earlier vigor and a readiness to assist her back to a dignified place among the newworld nations. This indicated not so much less faith in Texas as a greater belief in the inherent strength of Mexico, and a conviction that British interests were conserved where a reinvigorated Mexico could oppose itself to the United States, should occasion demand it. Such a policy necessarily meant gentler pressure upon Mexico to recognize Texas. The change of tone in British policy is indicated by the change of tone in Pakenham's reports, for throughout his career at the Mexican capital Pakenham very accurately reflected the attitude of the government at home.

Up to I842 Pakenham had given the Texan government credit for honorable and upright methods, and had been flattered by the willingness of Texan agents to submit to his advice. In February he was the subject of a trick upon the part of Hamilton, who was making desperate efforts to regain prestige and influence in the affairs of Texas. Though already discredited at home, according to Kennedy's report, Hamilton asked Pakenham to transmit to Santa Anna a sealed packet, describing it as merely a personal letter " of a confidential character." The packet contained in reality an offer of a bribe to Santa Anna if he would make peace with Texas. While Santa Anna was only amused at Hamilton's cleverness in getting this bribe before him, and related the matter to Pakenham as a joke, Pakenham himself was naturally very angry, and jumped to the conclusion that Texan agents were wholly unscrupulous. ${ }^{1}$

${ }^{1}$ F. O. Mexico, I53, Pakenham to Aberdeen, February I7, 1842. 
In any case, Pakenham was now finding the new Mexican government more reasonable in its conduct of affairs than the previous government had been. A delicate situation had arisen in connection with the ill-fated and unauthorized Santa Fé expedition, in which some three hundred and twenty adventurers from Texas, seeking to revolutionize New Mexico, had been captured by Mexican troops in September, I84I, and sent to Mexico. Many of these claimed to be British citizens and traders, and denied having any part in a conspiracy to overthrow the government of New Mexico. Pakenham naturally doubted the honesty of such denials, but had to come forward and ask generous treatment for those who claimed his protection. $^{2}$ Believing the prisoners to be lawless adventurers, he was reluctant to act, and it was only after the American prisoners were released upon a threat from the American government that he bestirred himself to insist upon the release of British prisoners. His action in the matter was characterized by great delicacy, however, and reflected the new gentleness of treatment which Aberdeen affected toward Mexico.

While relations with Mexico were thus placed upon a better footing, those with Texas were endangered by Houston's declaration of a blockade of the Mexican coast. To Pakenham such a blockade seemed preposterous. Any effective blockade of such a stretch of coast he believed it absolutely impossible for Texas to maintain. In addition, he construed this Texan block-

${ }^{2}$ F. O. Mexico, 153, Pakenham to Aberdeen, January 3I, and February 17, 1842. Among these prisoners was one Falconer, a brother-in-law of Roebuck, a prominent member of the British Parliament. 
ade as showing a lack of consideration for British interests in the Gulf of Mexico, and wrote that the blockade was " a foolish attempt to intimidate and insult the Government of Mexico; but what is more deserving of attention as far as we are concerned is the disregard for the interests of neutral trade manifested by the Government of Texas in resorting to a measure of this kind, and under such circumstances." Evidently Pakenham expected Aberdeen to refuse to acknowledge the blockade and he urged immediate action, since, in the event of damages to British vessels as a result of the blockade, it would be impossible to obtain satisfaction from the Texan government. ${ }^{3} \mathrm{He}$ cited the instance of the "Eliza Russell" as a case in point. The explanation of Pakenham's attitude in this connection must be found in the changed point of view of the British ministry, as no action of Texas at this time would warrant so radical a change of temper.

The blockade did indeed vex the British government, although at first the determination was made to recognize it, and notification that it existed was duly printed in the "Gazette." British merchants were not slow to protest, and such pressure was exerted that it is not strange that in September another item in the "Gazette" gave notice that Great Britain refused longer to recognize it. ${ }^{4}$ Fortunately, before this date, and before Great Britain's action could be known

${ }^{3}$ F. O. Mexico, 153, Pakenham to Palmerston, April I6, I842.

4F. O. Mexico, I58 and I59, Dom. Var. These volumes contain many letters of protest against the recognition of the blockade. The letters are numerous during May and June, and the Mexican and South American Association of Merchants in particular made vigorous protests, repeating them nearly every week. 
in Texas, Houston, on September 12, had himself recalled the declaration of blockade. Without question the entire proceeding was a mistake. It served no purpose, and only resulted in a momentary irritation at London. It was fortunate for Houston's position that he had revoked the blockade before he knew of Aberdeen's refusal of recognition. Thus up to midsummer of 1842 British policy was clearly directed toward maintaining friendly relations with Mexico, with slightly less deference to Texan interests. With no intention of sacrificing the interests of the newer state, and with a determination to keep within such bounds as would bear international scrutiny, there was a distinct emphasis upon British-Mexican friendship. In May of this year a situation arising out of the Texan-Mexican difficulties, and a direct result of the Texan blockade, called for the immediate attention of the British ministry. Aberdeen's conduct of this more or less intricate business carried the pro-Mexican policy so far that England was subjected to considerable criticism, and Texas at least was left with the impression that British neutrality was more nominal than actual. In April of 1842 there was brought to light a contract between Murphy, the Mexican minister to Great Britain, and the English firm of Lizardi and Company for two vessels of war for the Mexican government. One of these vessels, the "Guadaloupe," was built at Liverpool, and was to be ready in June. The other, the "Montezuma," building at London, was to be delivered later. Both were iron war-ships, the crews were to be recruited in England, and they were to be sent to Mexico under the command of offcers in the English navy who had secured leaves of 
absence for that purpose. Various Englishmen interested in Texas believed that these vessels had been contracted for under Melbourne's ministry, and that the Admiralty was responsible for their plans and models. This seems wholly unlikely in view of Palmerston's friendly attitude toward Texas, and there is nothing in the correspondence at the Record Office to corroborate such a suspicion.

The first reference to the matter occurs in a correspondence between Murphy and Aberdeen in the spring of $1842 .{ }^{5}$ This shows that Lizardi and Company had agreed to furnish the two steamers to Mexico and that delivery was to be made at Vera Cruz. It must be assumed that the attention of the foreign office was first attracted to the negotiation for the Mexican ships when, on April 28, a communication from Lizardi and Company was received asking permission to place cannon on board and otherwise arm the vessels. On May II Aberdeen wrote Murphy desiring him to explain or confirm the statement of Lizardi and Company. In reply the Mexican minister vouched for the statements made, and asked that the ordnance office be instructed by Aberdeen to authorize the regular agents for the supply of guns to English vessels to furnish cannon for

- The letters treating of these two vessels appear in various documents. The correspondence between Lizardi and Company and the foreign office, and that between the foreign office and the ordinance office, is in F. O. Mexico, 158, Dom. Var. The letters between Murphy and Aberdeen are in F. O. Mexico, 157, Dom. Those between Smith and Aberdeen are in F. O. Texas, 5. In detailing this incident the footnote references will not be cited except where it is necessary to state the date of a letter. In each case the exact references may be found by referring to the general statement just made as to the place of correspondence. 
these ships. To this request no immediate reply was made, and Murphy was left to draw what conclusion he might. It goes without saying that without Aberdeen's permission nothing could be done about arming the ships.

In the meantime, Kennedy, acting as Texan consulgeneral in London, got wind of this affair and bestirred himself immediately. In conjunction with Ashbel Smith, the new Texan minister to Great Britain, whose arrival on May Io was most opportune, a protest was prepared voicing what they assumed to be the Texan point of view and urging the detention of the vessels. ${ }^{\circ}$ This protest, presented to Aberdeen on May 30, was reinforced by a personal communication from Smith, who, in his official capacity, had other matters to present to the foreign secretary. Smith's errand to England charged him with the closing formalities in connection with the exchange of ratifications of the British-Texan treaties, and the discussion of that

- Ashbel Smith was born at Hartford, Connecticut, in I805, and was educated at Yale, receiving his collegiate degree in I824 and his medical degree in 1828 . He at once went south in search of practice and carried on his profession in North Carolina until 1836, at which time he removed to Texas and immediately became identified with political affairs there. President Houston selected Smith as the best man to be sent to England to secure the ratification of treaties and the friendship of Great Britain. Smith was recalled in 1844, and was for a short time secretary of state under President Anson Jones. $\mathrm{He}$ served in the Mexican War and again in the Confederacy. After the Civil War he retired to a plantation near Galveston, resuming his practice only in times of emergency, as on the appearance of the yellow fever scourge. He wrote many scientific treatises, helped found the University of Texas, and was a regent of that institution. He died in 1886. 
affair gave opportunity for a word in behalf of the protest. The important business of Smith's visit to London was, of course, the conclusion of treaty arrangements, and the fact that in the last ten days of May he addressed a number of letters to Aberdeen urging immediate ratification shows that he was bending every energy toward gaining his end. Possibly he hoped to have finished with the treaties before pushing the other matter, and he may have feared that a criticism of British action might imperil the success of his real enterprise. This would account for the delay in presenting the protest.

Between May II and May 3I no acknowledgment of Murphy's petition was made and no authority was given by Aberdeen for placing arms on board the vessels. On May 3I, however, a letter was finally drafted in the foreign office which refused to authorize Lizardi and Company to arm the ships, but permitted the purchase of the arms themselves. To justify this extremely fine distinction, Aberdeen argued that there was no reason to object to a purchase of arms if they were placed in the hold of the vessel and not mounted while the vessel was in an English port. The letter, which was addressed to Murphy, regretted the inability of the foreign office to grant the authorization asked, but instead of being despatched to Murphy it was promptly pigeonholed. Some ground of uncertainty or suspicion in Aberdeen's mind, perhaps due to the protest and visit of Smith on May 30, or to his various letters of the ten days preceding, may have operated to withhold the letter to Murphy. At any rate, Murphy was still kept in ignorance of Aberdeen's intention, and it was not until June 2 that any action was taken at 
the foreign office which served to enlighten him. On that date Aberdeen finally transmitted to the ordnance office a formal request to permit Murphy to purchase arms from the firm of Walker Brothers, of the Gospel Oak Iron Works. On June 7 the ordnance office gave its authorization. This arrangement was really quite in harmony with the plan outlined in Aberdeen's letter to Murphy of May 3r, as it is evident that the minister still had in mind the plan of permitting arms to be placed on board the vessels in case they were not mounted and in position. But this same letter to Murphy was still held back and, in fact, was retained at the foreign office for six weeks before being transmitted.

With the consent of the ordnance office, preparations regarding arms for the Mexican ships advanced, and by June 14 Smith became convinced that the government was taking no steps to prevent the departure of the vessels. Apparently he had believed up to that time that, as a result of his interview with Aberdeen on May 30 , the British government would have nothing to do with these vessels and would even prevent their sailing. Finding himself mistaken, he immediately renewed his protest, only to be informed by Aberdeen that the action of the British government was not inconsistent with its neutrality, and that he had refused permission to the vessels to arm in English ports. The "Guadaloupe" sailed for America the same month.

Meanwhile, Smith and Aberdeen were fast coming to an agreement with regard to the Texan treaties, and on June 28 those treaties were finally ratified, thus completing British recognition of the indepen- 
dence of Texas. Smith's conduct of this difficult affair was characterized by dignity and skill, and the fine diplomatic form of his correspondence won for him Aberdeen's warm personal approval. Succeeding Hamilton of doubtful methods and uncertain motive, his demeanor and success were the more noteworthy, and his correspondence was wholly different in tone from that of his predecessor. Smith did not drop the subject of the Mexican ships without another effort, and, after learning of the departure of the "Guadaloupe," he renewed his protest, indirectly accusing the British government of having really prepared these vessels and fitted them out in order to aid Mexico in striking a blow at Texas. Without waiting for the results of his communication, he then went to the Continent.

Apparently 'Aberdeen was in a quandary. The "Guadaloupe" had left England in June. The offcers and crew were already enlisted for the "Montezuma," and she also was nearly ready for departure. English naval officers had secured the permission of the Admiralty to go out in command of the vessels. To the granting of this permission Aberdeen had made no objection, and the "Guadaloupe" had sailed under English officers. Later, however, a letter from the Admiralty to Addington shows that Aberdeen had expressed a desire for the recall of such permission, and on July 7 Aberdeen recommended that the leave of absence granted to the officers be stopped at once. This was done on July 8, but even in carrying out Aberdeen's suggestion the Admiralty opened a way for the officers by stating that there was no objection to 
their retaining their situations on board their vessels if those vessels were unarmed. ${ }^{7}$

On July I5 Aberdeen's letter of May 3I, containing permission to buy arms but not to mount them on board, was finally brought to light and transmitted to Murphy. On the following day, July I6, Aberdeen assured Smith by letter of his refusal to permit the arming of the vessels. That he knew that guns were being placed on board at that very time there can be no doubt, and it is also clear that he preferred not to state the whole case to the Texan minister. It was necessary to steer a middle course to maintain the friendship of Mexico and at the same time make reasonable concessions to Smith's demands. He wrote, "The British Government are determined to maintain a strict neutrality in the contest between the two powers and not to give to the one a facility or advantage which is not equally conceded to the other." Adding further, "No English official holding the Queen's Commission will be allowed to serve in the Mexican Navy against Texas."

To complicate further the already difficult situation of the "Montezuma" both for the foreign office and for the Mexican purchasers, the customs officials were notified of the boat's sailing and obliged to take a hand in the matter. General Hamilton, who was once more in England, presented to the customs officials an affidavit stating that the "Montezuma" was about to sail in violation of the Foreign Enlistment Act. By that act " the treasury board was empowered to seize and confiscate vessels equipped, furnished, fitted out, or

\footnotetext{
'F. O. Mexico, I58, Dom. Var., Barrow to Addington, July 8, 1842 .
} 
armed to make war against a country at peace with England."' The customs authorities decided that the law had been violated, and held the vessels until the matter could be referred to some superior authority. The facts in the case were that Lizardi and Company, acting under the authorization of Aberdeen given in the first week in June, had placed guns, ammunition, and other utensils of war in the hold of the "Montezuma," and had made such other preparations as would have permitted the mounting of these guns in a very short time. When the customs officials prevented the departure of the "Montezuma" and the Admiralty ordered Captain Cleaveland of the British navy to leave the vessel, both Lizardi and Company and Murphy thought themselves ill used by the English government, and on August I7 Murphy protested to Aberdeen, recalling to his attention the authorization of the ordnance office on June 7. Aberdeen's answer, on August 22, was that the foreign office had no control over the customs officials in such matters, but an investigation would be made. Murphy regarded himself as deceived, and protested that he had followed exactly the suggestions made by Aberdeen. Aberdeen's reply was that " it is not the fact of arms having been placed on board the 'Montezuma' which has occasioned her detention; but the circumstances of her general equipment and fitting up as a ship of war."”

" 8 Worley, 23.

'It appears in F. O. Mexico, 159, Dom. Var., that before Murphy protested against the detention of the "Montezuma," Aberdeen had heard of the matter and had investigated it. He was without question surprised at the action of the customs officials, and was somewhat troubled and annoyed by it. Aberdeen to Sir George Clarke, August 15, 1842. 
In the end, after being held for nearly a month, the "Montezuma" was permitted to sail, but only after being stripped of most of her equipment and with her crew reduced to meet the requirements of an ordinary merchant vessel. Captain Cleaveland resigned his commission and went with the ship. Even this reduction in numbers and change in the equipment of the "Montezuma" did not satisfy Smith, and just before the departure of the vessel on September I4 he again addressed a vigorous communication to Aberdeen, protesting against the departure of the vessel under any conditions. On September I9 Smith went so far as to assert that if the "Montezuma" were permitted to join the "Guadeloupe," the people of Texas would certainly believe that Great Britain was seeking to aid Mexico. In his reply of September 27 Aberdeen defended his attitude with dignity and without apology, asserting that if the British government had desired to do so, it had a perfect right to permit Lizardi and Company to arm the vessel, and that its refusal was unmistakable evidence of its desire to preserve strict neutrality.

That Aberdeen lacked perfect confidence in his own protestation may be assumed since at this very time in letters to the admiralty he expressed his vexation that the English officers had been permitted to go with the ships. On October Io Smith presented to the foreign office a very able and comprehensive argument directed against Aberdeen's interpretation of the duties of Great Britain as a neutral. A perusal of this communication reveals a familiarity with documents in the American embassy. This is not remarkable in itself, as Smith was in fact in close touch with the 
American minister at the time, yet the revelation of any such intimacy was a distinct tactical error upon his part if he desired to secure the friendship of Great Britain for Texas, and it did not take him long to realize this. After the exchange of a few more letters bearing upon the much discussed subject, Smith suddenly dropped all communication with regard to the ships, and never again referred to them. Indeed, in a private letter to Houston he later acknowledged his error in continuing his protests after the vessels had departed, while Houston himself took the ground, and adhered to it ever afterward, that there had never been any occasion for protest.

The question of international law here involved is precisely the same as later attracted wide-spread attention in the famous "Alabama" case during the progress of the American Civil War. In the present study, however, the chief interest hinges upon the probable motive of a foreign minister who with uncertainty and vacillation was seeking some guiding principle in the matter of the ships. It is likely that the Texan declaration of a blockade had some part in persuading Aberdeen to wink at the semi-official assistance given to a strengthening of the Mexican navy. It is possible that he justified the purchase of arms for the ships merely as a matter of indirect protection to British trade. If Pakenham's interpretation of this incident was correct, then Aberdeen was influenced by both of these motives. Pakenham knew nothing of the fitting out of the ships until some time after the correspondence in regard to them had closed. On September Io he wrote to Aberdeen ${ }^{10}$ giving an ac${ }^{10}$ F. O. Mexico, 155 . 
count of the arrival of the "Guadeloupe," and stating that the English officers recently enlisted in Mexican service had been very careful to make it known that they had come without official British sanction. At the same time, British consuls were keeping in close touch with these English officers, and they were freely tenlered such advice as might make them effective in their new capacities as officers of the Mexican navy. The success of this new Mexican naval force, commanded by English officers, Pakenham believed assured, and he predicted that the Texan navy would soon be swept from the Gulf of Mexico. He wrote that he expected soon to hear that the "Guadeloupe" "has captured or destroyed the Texas vessels." At the time he wrote this letter Pakenham certainly believed that the vessels were definitely intended by Great Britain to aid the Mexican government, and, consequently, that the British government, while technically neutral, was really hopeful of a Mexican victory over Texas.

In fact, this seems the only reasonable explanation of Aberdeen's policy. That policy was wholly in line with what had gone before in 1842 , and indeed the same policy was consistently maintained up to the arrival of Ashbel Smith. With the appearance of Smith, with his oft repeated protests, his personal influence, and his urgency in securing the ratification of the Texan treaties, there was a gradual divergence from what was probably the outlined course; Aberdeen was forced to reconsider, he hesitated, and then adopted the policy of neutrality. Soon after came the signing of the Texan treaties, and Aberdeen, as was stipulated by these treaties, was obliged to go a step beyond mere indifferent neutrality in the effort to persuade Mexico to recognize Texas. This will appear later. 
No active steps were taken in this direction, however, until after July. At this same time, also, it must be remembered that Aberdeen was vitally interested in the Ashburton negotiation in the United States, which had for its primary object the settlement of the vexed question of the northeastern boundary, but was intended also to secure, if possible, a removal of all causes of friction between Great Britain and the United States. Palmerston's retirement in England, and the appointment of Webster in America to the position of secretary of state had seemingly opened the way for a general adjustment of all difficulties pending between the two nations. The selection of Ashburton as the British negotiator of the proposed treaty was unquestionably intended to emphasize the conciliatory and friendly attitude of the government. ${ }^{11}$

Ashburton arrived in America in April, and his first reports were sanguine, stating the friendliness of his reception and the readiness of Webster to negotiate. He believed it possible to settle all matters in dispute. ${ }^{12}$

${ }^{11}$ F. O. America, 378, Aberdeen to Ashburton, February 8, 1842. This gives the instructions under which Ashburton left England. Aberdeen specified five points requiring negotiation, and stated them in what he considered the order of their importance: (I) northeastern boundary; (2) Oregon boundary; (3) northwestern boundary, i. e., "frontier from Lake Huron to Lake Superior and from Lake Superior to the Lake of the Woods;" (4) the affair of the "Caroline;" (5) right of search. Aberdeen hoped that a treaty might be negotiated covering all these points. After Ashburton had sailed, supplementary instructions were sent him on March 3I, but these in no way limited the scope of the negotiation. Thus, contrary to Webster's assertions, Ashburton did have specific instructions. In the end he ventured to break a way from them, when he came to realize that the negotiation would be more difficult than had been anticipated.

${ }^{12}$ F. O. America, 379, Ashburton to Aberdeen, April 25, 1842. 
This information was received in London just as the affair of the ships was coming to a head and almost coincident with the arrival of Ashbel Smith. There is no question that the negotiation in America had a direct bearing upon British policy toward Texas, and that the rosy prospect reported by Ashburton increased 'Aberdeen's disinclination to pursue Palmerston's policy of aiding in the creation of a powerful, independent state in Texas. ${ }^{13}$ Both from the point of view of established British policy in support of Mexico and with the object of creating no embarrassments for Ashburton's negotiation, Aberdeen preferred to strengthen Mexico rather than Texas. A few weeks later, however, it had become evident that Ashburton had greatly overestimated the probable success of his mission, and that far from settling all points in dispute with the United States, he would be forced to content himself with a solution of the northeastern boundary difficulty and of a few minor questions. Even in the matter of the boundary Ashburton finally exceeded the limit of concessions permitted him by his first instructions. The treaty was indeed hailed in England as wholly satisfactory, and much credit for

${ }^{13}$ Alexander Baring, first Baron Ashburton, was born in 1774 and died in 1848 . His selection as British negotiator in I842 was definitely intended to indicate England's friendly and conciliatory policy toward the United States, for Ashburton was well and favorably known in America. As a young man he had represented in Philadelphia his father's financial house, and had married in 1798 Miss Bingham, a belle of the city. He had a better acquaintance than most of his countrymen with American conditions, and frequently opposed, both in the press and in Parliament, British restrictions on American trade. Ashburton's selection was popular in the United States. 
it was claimed by the ministry. In reality it was a distinct disappointment to Aberdeen, not so much because of any yielding on the boundary question as because of the failure to settle other matters. He knew by the first of June that the scope of the treaty would be greatly limited, and with this knowledge recognized the failure of his plan to place relations with the United States upon the basis of extreme friendship. A natural reaction brought him more and more to the idea of an independent Texas as a necessary barrier to American expansion, and thus gradually he recurred to Palmerston's plan. If Ashburton had succeeded in carrying through the original purpose of the British ministry and had settled all matters in dispute between the two countries, it is possible that Aberdeen might never have entered upon any plan to prevent the American annexation of Texas, though still distinctly opposed to it. But with the failure of the larger plan, he was more ready to become active in preventing that annexation, and to aid in the establishment of a powerful and independent Texan State. 


\section{CHAPTER V.}

i842, July to December. First British Offer of Mediation. Elliot in Texas.

The exchange of ratifications which finally made the British-Texan treaties effective took place in London on June 28,1842 . It is worth noting that, as the wearisome negotiations looking to ratification were progressing in England, sentiment for Texas, or at least confidence in Texas, was on the wane in many quarters. England's duty, then, of urging upon Mexico the recognition of the new state was likely to be more perfunctorily than heartily discharged. In some measure this was due to rumors from Texas of the insecurity of the government and the lack of character and discipline in the motley Texan army. Pakenham's reports from Mexico during the greater part of $\mathrm{I} 842$ were all such as to confirm this rather vague distrust of the Texan Republic, and as early as April of that year they expressed the belief that Texas was no longer to be regarded as a powerful state, and that the Texans were themselves weary of independence and were looking toward annexation to the United States. Pakenham sent this information immediately after receiving a private letter from Kennedy, who was then in Texas, and without the knowledge that Kennedy had been commissioned by Aberdeen to report upon Texan 
affairs. ${ }^{1}$ In June, Pakenham sent to the foreign office an account of a New Orleans newspaper attack upon the British government. This paper accused England of encouraging Mexico in a vigorous opposition to the United States, and further, spread the rumor that England had guaranteed a loan of six million dollars to Mexico to enable her to reconquer Texas. ${ }^{2}$ Pakenham denied the first accusation absolutely, stating that he had consistently endeavored to encourage harmonious relations between the United States and Mexico. In regard to the loan he admitted that these rumors had indeed some foundation, and gave the details of an offer that had been made to Mexico to raise thirty million dollars in England, half of which was to be paid in bonds of the old Mexican debt, while fifteen millions in cash were to be transferred to the Mexican government. The purpose of this plan was wholly commercial. In return for the loan, Mexico was to repeal import duties on cotton goods and to discontinue governmental support for the manufacture of cotton goods in Mexico. The plan provided that Great Britain was to guarantee the loan. Pakenham had definitely encouraged the promoters of this scheme because he thought it would result advantageously for British trade. He had no confidence that the British government would guarantee this loan, but hoped some

${ }^{2}$ F. O. Mexico, 153, Pakenham to Aberdeen, April 7, 1842.

${ }^{2}$ Newspapers throughout the United States copied this statement, alloting much space to it and to similar rumors, and thus giving wide publicity to the notion that Great Britain was preparing to interfere in Texan affairs. Similar rumors had appeared before this, but none purporting to be based on such reliable information, and none furnishing such exact details, as in this case. 
other nation might. He was not so blind as to suppose for a moment that Mexico would use such a loan merely in the development of her general resources, but understood perfectly that money so secured would be immediately used in the preparation and equipment of an army to reconquer Texas. He was none the less in sympathy with the plan on that account, and, believing also that the home government would not withhold its sanction, he thought such a plan permissible and in line with British political interests. ${ }^{3}$

This plan for a loan is cited here, not because it brought any direct result, but because it indicates the trend of a policy. If Pakenham is to be regarded as reflecting what he understood to be Aberdeen's policy, then it is evident that the cardinal principle of that policy demanded, first, support for the Mexican government. That much outside sentiment also favored governmental support of Mexico, even at the expense of Texas, is attested by the large number of unofficial letters addressed to the foreign office about this time. Among these, for example, was one from Captain $\mathrm{H}$. Martin, an officer in the British navy, to Sir Robert Peel, written on July I, I842, from Hamburg, urging upon the government the definite policy of strengthening Mexico and refusing recognition to Texas. The writer interpreted a recent speech by Peel in Parliament to mean that England would refuse such recognition until Texas should have abolished the slavetrade. He reasoned that Texas was but waiting for British recognition to stir new trouble with Mexico and force the United States into a policy of annexation. Martin's information and his predictions were

${ }^{3}$ F. O. Mexico, I54, Pakenham to Aberdeen, June 2, 1842. 
based upon letters received from Santa Anna, of whom Martin could speak from personal acquaintance, and he concluded his letter by urging Peel to break away from the follies of Palmerston's foreign policy. ${ }^{4}$ Martin wrote but two days after the treaties had been ratified, and of course could not know that the recognition he desired to avert was already a thing accomplished. His letter was but one of the many offering gratuitous advice to the government at a time when its policy in regard to Texas had not been unfolded. Many of these communications contained information and expressed ideas which had a real bearing upon the questions involved and would undoubtedly influence the ministry. The public was not in the confidence of the government, and until the treaty ratification was announced could interpret no definite intention from Aberdeen's official acts. The writers undoubtedly hoped to influence his policy. Yet the public itself was hardly more in the dark as to Aberdeen's ultimate purpose than he himself seems to have been. From whatever point of view the question is approached, and from all available information, it seems certain that until the ratification of the treaties Aberdeen was in doubt as to just what policy it was best to pursue. This is borne out by the facts cited in connection with the "Guadeloupe" and the "Montezuma," by the protests from Murphy and Smith respectively and Aberdeen's letters in reply, by Pakenham's correspondence, and by letters from private persons.

With the ratification of the treaties one feature of

'F. O. Mexico, 158, Dom. Var. 
British policy became clearly marked, and the necessary instructions from the foreign office fulfilling England's share in the compact were promptly sent. Aberdeen's instruction to Pakenham, dated July $\mathbf{r}$, was very carefully worded. ${ }^{5}$ While the arguments presented differ very slightly from those advanced by Palmerston, which so angered the Mexican government and people, the form of the instruction was much more considerate and courteous. Pakenham was to tell the Mexican Cabinet "that it is the earnest desire of H. M. Govt. to see peace permanently established between Mexico \& Texas, that considering the powerful support with which Texas is likely to meet from the People-I speak not of the Govt.-of the United States, and the unlimited means of recruiting her forces both by land and Sea, which are within the reach of Texas by reason of her proximity to that Country, the sentiments of whose Citizens in general are strongly in favour of the Texians, H. M. Govt. can not but perceive all the difficulties which are likely to surround Mexico in her renewed attempt to recover possession of the sovereignty of Texas." Thus Aberdeen acquitted the United States government of any duplicity in connection with Texas. Aberdeen believed also that Texas might actually become the ally of Mexico at some time in the future, and it is interesting to note that he believed the United States destined to break up into separate states. "Furthermore, a Nation which must, and will, one day become populous and powerful, would be thus interposed between Mexico and the United States:

${ }^{5}$ F. O. Mexico, I52. 
and, in all probability, looking towards remote times, that Nation will become the ally, and main protection of Mexico either against the United States, or against those States conterminous with Texas, into which that portion of the United States may in future times have separated." In addition to the warning given to Mexico for its own salvation, Mexican pride was appealed to in Great Britain's expression of her friendship and her paramount interest in Mexico. "The Mexican Govt. must be conscious that Great Britain can have no other object than to counsel that line of conduct which is sincerely and honestly believed by them to be most advantageous to Mexico. Our inclinations and our interests equally concur in making us desire to see Mexico peaceful, prosperous, and happy: and, under the impression of these sentiments, H. M. Govt. advise that course which they consider most fitted to bring about such a result."

The ratification of treaties on June 28 forced this formal and perfunctory instruction of July $I$. It was wholly in line with Aberdeen's state of mind at the time. In the fortnight that succeeded the forwarding of this instruction several events of lesser consequence in London may be recalled. It will be remembered that the foreign office, on July 8, withdrew a permission given earlier for English officers to go out with the "Montezuma," that on July I5 Aberdeen finally sent to Murphy the long-delayed letter of May 3I, stating the decision reached with regard to the arming of the "Montezuma," and that on July 16 he addressed a note to Smith, asserting that England's policy was one of strict neutrality. Recalling the persistence and energy of Smith at the time, his frequent protests, and 
the demands made upon Aberdeen's tact and skill in connection with the Mexican ships, and recalling also that just at this time it was evident Ashburton's mission to America would be only partly successful, it is easy to see that the fortnight following the first instruction to Pakenham was charged with activities foretelling a more definite policy. These events and considerations resulted in the sending on July I $_{5}$ of a second instruction to Pakenham upon the question of Mexican recognition of Texas in which Aberdeen exhibited a real anxiety for fear some folly on the part of Mexico would drive Texas into the arms of the United States. All of the old arguments were repeated, but were here stated in much more emphatic language. ${ }^{8}$ In particular, Aberdeen laid stress upon the difficulties of a Mexican reconquest of Texas, and prophesied that annexation to the United States would be a not impossible result. "You will represent to them the impossibility of preventing the interference of the People of the United States in this Contest: and you will endeavour to convince them that in the present state of publick feeling in that Country, neither the Supreme Government at Washington, nor the Local Governments of the States, however well disposed they might be to do so, could put a stop to that interference."

$\mathrm{He}$ added, "even supposing the Mexicans should be able to overcome the difficulties which would be opposed to them by this increased assistance on the part of the United States, the result, after the most brilliant successes of the Mexican Arms, would probably be, that the Texians would be compelled to in-

'F. O. Mexico, I52. 
corporate themselves with the United States." In conclusion, Aberdeen warned Mexico that Great Britain would not assist her in any contest in which she became engaged with the United States: "Nor should they allow themselves to suppose that they can at any time count upon succour from Great Britain in their struggles with Texas, or with the United States. Great Britain is determined to remain strictly neutral." The sending of this second instruction so soon after the first can have no other explanation than that for some reason Aberdeen was exercised and anxious upon the subject of annexation. This was probably the result of the discovery that Smith was in close touch with the American minister in London, and that in his protest against the arming of the "Montezuma" many of the documents cited in support of his case were drawn from the archives of the American ministry. Aberdeen was not convinced that American annexation was imminent. But in this month of Júly his position, which had hitherto been characterized by indifference or at least uncertainty, was rapidly shifting toward that held by Palmerston. $\mathrm{Up}_{\mathrm{p}}$ to this time, however, it is perfectly clear that British policy under Aberdeen was based less on any belief that the Texan State would be of service to England than upon the conviction that a Mexican recognition of Texas was essential to the consolidation of Mexico itself. British interests in America demanded a strong barrier to the south of the United States, and Mexico seemed most likely to furnish this.

Upon the receipt of Aberdeen's first instruction, Pakenham at once placed the matter before the Mexican Cabinet. ${ }^{7}$ The foreign minister, Bocanegra, ex-

'F. O. Mexico, 154 . 
pressed in "vehement" language his sense of the injury to Mexico in Great Britain's recognition of Texas, and stated that Mexico would henceforth suit her commercial policy to her own needs and not to the needs of such half-friends. Santa Anna was more courteous, but replied to Pakenham "that the Government and people of Mexico had, since some time past, come to a deliberate and conclusive resolution upon the subject of Texas from which they could not now recede." 8 Pakenham appreciated fully that this first instruction from Aberdeen was but a formality required by the treaty with Texas, and, satisfied that his duty was fulfilled in presenting the matter to the government, he made no effort to push it. He was, in fact, convinced that Santa Anna's government rested upon a purely military basis, that even in Mexico such a government could not exist long without a plausible excuse, and that this excuse lay in the projected reconquest of Texas. And indeed the reconquest of Texas, if the attempt were made with energy, seemed far from an impossibility even to Pakenham. His knowledge of the weakness of Texas was based upon "the accounts which have been constantly received of the unpromising condition of that Country, the apparently hopeless derangement of its finances, and the failure which seems to have attended the attempt to organize an efficient and disciplined Military force composed of volunteers from the United States." 9 Possibly it was merely the wisdom of the diplomat that recognized the hopelessness of Great Britain's demand upon Mexico, and that, in reports to the home government, empha-

${ }^{8} \mathrm{~F}$. O. Mexico, 154 .

- Ibid. 
sized an alternative policy, or at least its possibility. His despatches, however, give the impression that he was really sincere in ceasing to be an advocate for Texas and indirectly urging support of the Mexican government. But Pakenham was too thoroughly trained in diplomacy and understood too well his relations to those in authority at home to press any plans that might conflict with those of his superiors.

Until now the main centers of interest and of action in British-Texan relations had not been in Texas itself, but in London and in Mexico. Save for the semiofficial tour of Kennedy, no diplomatic representative of Great Britain had as yet gone to Texas, but the time had now arrived when one must be sent. The commission of Captain Charles Elliot to act as chargé d'affaires in Texas bore date of August 20, I84I, ten days previous to the resignation of Melbourne's cabinet. His appointment was confirmed by Aberdeen, but his departure was to be postponed until England should receive notice that Texas had ratified the treaties. It was not in fact until Kennedy's return from Texas that that notice could be sent to Elliot, on May 27, 1842. After that, personal matters further delayed Elliot in setting out, and it was June I before he started upon his mission, reaching Texas on August 23. Under an amended commission he was given the title of consul-general as well as chargé d'affaires. He was by no means an inexperienced official, having already served in various positions, though up to this time in such as required administrative rather than diplomatic ability. Born in I80I, he was the son of Hugh Elliot sometime minister to Saxony and the intimate friend of the younger Pitt. He thus inherited 
a claim to place and influence, and was rapidly pushed forward. His uncle, Gilbert Elliot, had been much associated with Burke, and both uncle and father were profoundly affected by the political theories of the French Revolution, writing and speaking much on the questions of the day, usually on the conservative side. Thus naturally came those philosophical and humanitarian conceptions which inspired Charles Elliot's activities in Texas. Entering the navy in 1815 , he had been rapidly advanced, but in 1828 , while still nominally in the navy, he had been assigned to administrative posts, and thereafter continued in that service. From I830 to I833 Elliot was Protector of Slaves in Guiana; in 1834 he became secretary to the Trade Commission to China; in 1837 he was appointed chief superintendent and plenipotentiary at Canton. This was just the period when China had officially determined to put a stop to the opium traffic, then largely in the hands of British merchants and importers. The result of Chinese restrictions on the trade was much smuggling, so that in the end the Chinese government demanded that all opium in the hands of British merchants be surrendered. Elliot, in order to avoid a general massacre of foreigners, complied with the demand, and handed over some four hundred million pounds worth of opium, which was then burned. There was of course intense excitement, English residents were denied supplies, and Elliot, by leading an attack on Chinese war-junks, precipitated the "Opium War" which resulted so disastrously to China. The treaty which followed was arranged by Elliot, but was later disavowed by both Great Britain and China, and Elliot was recalled. Discredited by 
failure, but not officially disgraced, he was sent to Texas merely to find a place for him-an excellent proof that Texas was not then considered an important post in British diplomatic policy. It must be remembered, however, that his appointment was originally made long before a strong man seemed needed in Texas, and that Aberdeen, in sending him, simply conferred upon him a post already promised. Such was the man who was to guide British action in Texas.

Elliot's first instruction from Aberdeen required him to make demands upon Texas in regard to the "Eliza Russell" and "Little Penn" claims, and to protest against the Texan blockade. ${ }^{10}$ Thus this instruction, dated July $\mathrm{I}$, two days after the exchange of ratifications with Smith, was written on the same day that Aberdeen transmitted to Pakenham his first and purely perfunctory instruction to suggest peace to Mexico. Aberdeen's indifference on July I thus led him to use Elliot to ask redress from Texas, and Elliot's first activity was far from conciliatory. It may be doubted if he relished the performance of a duty so unlikely to secure the good-will of Texas. His first interview with Houston, however, convinced him that there would be no difficulty about the blockade, and Houston's assurance that he had no complaint to make in regard to the armed vessels was cheering. ${ }^{11}$ In acknowledgment of Elliot's report of this interview, Aberdeen expressed pleasure at Houston's attitude and statements, and assured the Texan government that England would exert herself to secure peace from Mexico. ${ }^{12}$ For some months after his arrival Elliot

${ }^{10} \mathrm{~F}$. O. Texas, 4, Aberdeen to Elliot, July I, I842.

${ }^{11}$ F. O. Texas, 3, Elliott to Aberdeen, August 29, 1842. 
was in ill health, and displayed no great activity. $\mathrm{He}$ reported merely incidentally, and therefore perhaps the more effectively, that Texas could never be reconquered, and that the predatory border attacks by Mexico were extremely unwise, that they accomplished nothing for Mexico and were a constant source of irritation in Texas. In these earlier reports he did not even mention the topic of annexation. Indeed, Elliot's ill health during these months limited him to an examination of the ground and a superficial acquaintance with the situation.

By November his health had much improved, and by that time, also, observation and contact and a delightful optimism had all combined in the evolution of a grand scheme which is the chief topic of one whole volume of his letters. While the plan involved Great Britain's assistance in creating in Texas a strong, independent State, thereby assuring permanent British interests in Texas, there were other conditions and ramifications which made it inappropriate for Elliot to write in detail of his plan to Aberdeen. Instead of this, his letters were sent to Addington, a personal friend and a permanent under-secretary in the foreign office, whose long term of service under succeeding ministries made him the most trusted and influential member of the permanent staff. Elliot's letters to Addington, though nominally personal letters, were devoted to urging a definite plan of campaign in Texas, and they make up the greater part of Elliot's correspondence in 1842 . Their incorporation in the volume containing his despatches indicates that they were regarded in the light of official correspondence,

${ }^{12}$ F. O. Texas, 4, Aberdeen to Elliot, October 3, I842. 
though they were not formally addressed to the foreign secretary. ${ }^{13}$ The first of these letters is dated November $15 .{ }^{14}$ It contains Elliot's interesting account of Houston's remarkable career, and expresses a real admiration for the character of the man, his abilities, and his integrity. ${ }^{15}$ This estimate was based upon many conferences with Houston, for they had become intimate friends, and it is more than probable that many of the suggestions in Elliot's letters had their inception in this warm friendship. From the beginning of this close association it is apparent that Elliot believed in Houston, and that, as the intimacy progressed and permitted close opportunities for studying

${ }^{13}$ The first impression upon looking at these letters is that they would never be of any influence because of Elliot's illegible penmanship. Possibly a friend with experience and practice may have been able to decipher them fairly readily, but for any one else their reading involves laborious effort. The letters do, however, furnish valuable and interesting contemporary information upon governmental conditions in Texas. Elliot was very intimate with the leading men of that government, and his estimates of the abilities and intentions of such men as Houston, Jones, Ashbel Smith, and others, render his letters decidedly entertaining.

${ }^{14} \mathrm{~F}$. O. Texas, 4.

${ }^{15}$ Houston's remarkable history was already well known in the United States, and through Kennedy and Elliot it soon became a matter of wonder and comment in England. The qualities that carried Houston from one dramatic incident to another, his energy, lawlessness, fondness for wild frontier life, bravery in battle, his success in politics, renunciation of official position and return to frontier life when he lost the love of his wife, his reappearance in the Texas struggle and rapid elevation to leadership there-all combined to throw a halo of romance about Houston that strongly appealed to the imagination of Englishmen. Houston's story, indeed, had great influence in making Texas and Texan conditions known in Great Britain. 
his friend, his confidence in Houston's sincerity increased. If Elliot was correct, there was but one man in Texas capable of dealing with the situation there, and that man, the president, aspired to be the founder of a great and independent state. The corroding evil in this promising state, and the chief obstacle to its greatness and independence, according to Elliot, were one and the same-the institution of slavery. The plan which he unfolded bore especially upon the extinction of slavery, and combined with the philanthropical measure certain great practical advantages that might be secured for British commerce. In this first letter he stated very explicitly what his plan was:-

My scheme supposes another Convention in this Country.Slavery to be abolished; the entire abolition of political disabilities upon people of Colour, perfectly free trade to be declared to be a fundamental principle; the right of voting to depend upon a knowledge of reading and writing, and a pretty high money contribution to the State, . . . stringent legislation against squatting, in the form of a land tax and otherwise; improvements upon the well established failure and folly of a yearly elected Legislature and other liberality of the rhodomontade school. It seems to be scarcely doubtful that the Northern and North-Eastern parts of Mexico, from Tampico on the North-East Coast, to San Blas on the West (involving the most important parts of the Country) would soon find it their interest to join a state founded upon such principles, or at all events constrain their own Government into the adoption of an equally liberal scheme of commercial policy. Foreign Merchants, Foreign Capital, and foreign enterprise and principles would soon find their way into these great and rich regions by peaceful means, and the power of the United States on this Continent would be gradually balanced, and yet without motive for collision; Indeed it seems possible enough that the North Eastern States would not be disturbed to see the power of the South and West effectually limited, and a bound marked beyond which Slavery could not advance. 
Elliot was therefore emphasizing commercial advantages to Great Britain that would result from the establishment of a powerful and independent Texas, with the added possibility of a boundary line so extended as to take in a large slice of Mexico. It is not supposable that a new convention would have introduced Elliot's millennium, or that the rulers of a country whose population looked forward to annexation by the United States would abolish slavery, guarantee free trade, and extend the franchise to the blacks. The belief that the border Mexicans, whose chief interest had been in guerilla warfare with their northern neighbors, would voluntarily subject themselves to Texan authority was even more absurd. All this seems much too fantastic to deserve serious consideration, yet Elliot sincerely believed that these ideas could be carried out by the use of money to compensate the slaveholders in Texas, and that England could well afford to advance that money in the shape of a loan. In concluding his letter, however, he stated that this was but his private plan, and that officially and publicly he would of course take the ground that while Great Britain abhorred the institution of slavery for herself, she had no desire to interfere with it in other countries.

Elliot's suggestion of active British operations in Texas to secure the abolition of slavery there is of the greatest interest, for it was the first instance of British official expression in this connection. There is no evidence that the general plan was suggested to Elliot by Houston, yet in the light of the intimate relations existing between them it is impossible to suppose that Elliot would have put forward such a 
plan if he had not discussed it at length with the president of the Texan Republic. Indeed, their relations were so close that such conferring may well be taken for granted. If Houston inspired Elliot's suggestion, what was his object? The theory of Reeves, in his admirable course of lectures given in 1906 on the diplomacy of Tyler and Polk, is that Houston probably used the suggestion of interference by England to frighten the United States, and intentionally advertised the close relations between England and Texas in order to urge the United States to action. Reeves, however, believes that Houston did not so direct his policy until the next year, I843. In support of this is the fact that up to November of 1842 no trace of any suggestion by British officials in authority that Texas abolish slavery is to be found, nor up to that time had there been even any suggestion to Mexico that she make the abolition of slavery in Texas a condition of recognition. This being true, Elliot's enthusiasm for the cause of abolition immediately after coming in contact with Houston may well seem significant, and may be pointed to as conclusive evidence of Houston's desire to make a tool of England. On the other hand, in defence of Houston's integrity and his honest desire for Texan independence, it must be admitted that it would have been perfectly logical for him to advance this very proposal in order to arouse in England a real interest in that independence. In the absence of positive evidence to overthrow it, Reeves's theory will doubtless find acceptance, and especially since it is the traditional view. Yet it can be seen that some testimony points toward a real desire for independence, and at this place in the narrative it 
seems well to leave the question of Houston's motives undetermined. The matter of motive is not perhaps essential to a study of British-Texan relations. Yet the puzzling question of Houston's intentions, and the many different interpretations that have been placed upon his conduct in his effort to guide the destinies of Texas, must always arouse interest. It may be said at once, however, that throughout all these negotiations, and even after the final annexation of Texas by the United States, both Elliot and Aberdeen believed absolutely in the sincerity of Houston and in his desire to establish an independent state.

Enclosed in Elliot's letter of November I5 was a personal letter from Houston, dated November 5, in which Elliot was requested to secure permission from Aberdeen to act as the agent of Texas in securing peace from Mexico. ${ }^{16}$ Elliot replied to Houston that he would quite willingly act in that capacity, but must await authority from London. In his letter of December II Elliot reported that the tone of Ashbel Smith's communication on the affair of the "Montezuma" had greatly angered Houston, who had asked him (Elliot) to express to Aberdeen the regret of the Texan government in regard to the whole matter. Houston's courteous apologies and his general complaisance were simplifying Elliot's undertaking and stimulating his hopes. In this same letter he further elaborated his plan, and stated that the possibility of its accomplishment was becoming more and more apparent. A week later, December 16 , rumors of annexation prevalent in Texas were troubling him, and

${ }^{16} \mathrm{~F}$. O. Texas, 4. 
he felt that delay in the execution of his plan would be fatal. He wrote:

"I cannot help thinking that money lent to put an end to slavery in a SouthWest direction in America and to give a place and position to the coloured races, would render as profitable returns as money spent in fortresses and military works on the Northern frontier of the United States." 17

Elliot emphasized more and more the humanitarian and philanthropic side of his plan, yet always coupled that aspect of his case with the distinct financial advantages to Great Britain. On December 28, writing again to Addington, he made a careful analysis of President Tyler's annual message to Congress, and interpreted it to mean that England was to keep her hands off Texas and Oregon, though there was certainly nothing in the message itself to warrant such interpretation. This warning, to Elliot's mind, was impudent presumption. At the same time he wrote that the Treaty of Washington recently signed by Ashburton and Webster was far from being regarded as a permanent settlement of the points in dispute between the United States and Great Britain. In the United States, on the contrary, it was considered as offering a respite only, and was certain to be followed by the renewal of a policy hostile to Great Britain when such a policy should seem most profitable. These arguments and the analysis given to Tyler's message were, of course, intended by Elliot to strengthen his plan for Texas.

Elliot's interesting personality combines the characteristics of the political dreamer and the honest philan-

${ }^{17}$ F. O. Texas, 4. 
thropist with that strong underlying patriotism which is always to be reckoned with in the Englishman of his type. Unfortunately, the qualities of real statesmanship essential to the realization of high ideals, especially the capacity to grapple with details and to give to environment and inherited instincts their proper value, were wholly lacking. He was genuinely a philanthropist in his desire to better the condition of the colored race, but he was also very genuinely an opponent of American expansion, and desired to see his own country assume a position upon the American continent that should check the further territorial advance of the United States. Like many of his countrymen, he had an inherited dislike for the United States, and a fear of its future greatness was his bogy. ${ }^{18}$

${ }^{18}$ Elliot represented very well that type of mind which is actuated by mixed motives; in this case moral sentiments and ideas of national profit were not necessarily conflicting sentiments, but it was impossible to discover which dominated. $\mathrm{He}$ was in sympathy with that sentiment in England which had caused a majority in Parliament to vote against a reduction of the sugar duties, on the ground that to reduce those duties would encourage the institution of slavery. On the other hand, the real fear of the future growth of the United States is shown in the works of every English traveler who visited America between 1835 and 1845 . The writers perhaps describe the wonders and the beauties of America, probably express amazement at its rapidity of growth in population and in prosperity, and charitably find excuses for crudities encountered, but all of them are really appalled at the progress of the United States, and are forced to apprehensive speculation upon the future power of America. The most striking illustration of this is the one fumished by Warburton, in his "Hochelaga." Warburton, who published his book anonymously, planned his American travels systematically, first visiting Canada, whose scenes and people and conditions he describes with care. He then came into the United States, 
None of the communications addressed by Elliot to Addington received any official answer from Aberdeen, nor is there anything in the records to show that any answer whatever was returned to him. In the meantime, Kennedy, throughout the summer of I842, had been urging upon Aberdeen that he be sent in some capacity to Texas. Kennedy did not, however, make any suggestions of a political nature, and when in the latter part of July he was appointed consul at Galveston, he was really more interested in a commercial venture there than in his official duties. His formal appointment was given him on September 29, but in a separate instruction of the same date he was emphatically and particularly warned to confine himself to his purely consular business and to leave diplomacy and policy to Elliot. ${ }^{19}$ Later this restriction was very burdensome to Kennedy and he tried in a variety of ways to evade it, but he was never permitted to play any part in political affairs. Kennedy sailed from England on November 16, and so did not reach Texas until the beginning of 1843 .

For the year 1842 there remains to be considered only the plan for a tripartite intervention by which England, France, and the United States were to urge

intending to spend a year or so in travel, but he was so surprised and impressed that he cut short his trip in order to return to London and publish a warning to his countrymen in the hope of arousing their attention to the terrifying rapidity of American advance, and to urge upon the British government that it bestir itself and take some step to guard against this new and threatening danger in the West. Elliot's letters convey much of this same impression. The prosperity of these years seemed to foreshadow a power and expansion in the United States which became a haunting fear with him.

${ }^{10} \mathrm{~F}$. O. Texas, 3 . 
peace upon the government of Mexico. Ashbel Smith at London had been instructed by Jones, the Texan secretary of state, to make a proposal for such an intervention to the governments of England and France. This was the occasion of his journey to Paris in the midst of the troubles of the "Montezuma" and immediately after the ratification of the Texan treaties in June of 1842 . He went to Paris then, in July, and secured from Guizot a promise to join in such tripartite intervention. The French ambassador in London proposed the measure to Aberdeen, but Aberdeen declined it on October 15. His excuse for refusing to join with the other two powers in the proposed intervention was that while the relations with England and Mexico were on a strictly friendly basis, those of the United States and Mexico were at the moment very critical. He did not feel, therefore, that he could sacrifice English relations with Mexico by joining with the other two powers. Aberdeen also stated that the proposed measure would have no result, since Great Britain had already in 1842 made two proposals to Mexico that she recognize Texas, and Mexico had declined. The incident of the tripartite intervention has often been overestimated by historians, both as a matter of importance in the historical study of the relations between England, Mexico, and Texas, and as indicating a selfish line of policy pursued by Great Britain. It was really much less significant than it seemed. No great emphasis was placed upon the matter by Jones in his instruction to Smith, by Smith in the proposal to Guizot, or by the French ambassador in suggesting it to Aberdeen. All these men seem to have regarded it as a measure which was worth an effort 
but of which there was really little hope. In respect to the selfish policy of Great Britain in this connection, surely Aberdeen might think that if Mexico did not accept the advice of that European power which stood in most intimate relations with her, she would not be likely to accept a suggestion made by the three powers. If, then, the plan was so unpromising of result, Aberdeen was perfectly justified in guarding British interests in Mexico by refusing to take a step that might irritate that government.

The year 1842 closed in Texas with Elliot on the ground, hopeful of his plan, enthusiastic over the possibilities of the Texan State in the future, and in his letters urging vigorous action by Great Britain to support the cause of Texan independence. Kennedy had not yet arrived, and British diplomatic policy so far showed no decided change of attitude toward Texas. The year had, however, witnessed a distinctly altered position on the part of Pakenham, whose reports from Mexico indicate an utter indifference to the movement toward Texan independence. In England, Ashbel Smith had made an excellent impression upon Aberdeen, and was proving himself an efficient and capable diplomat. Both in London and in Texas the official heads of that State inspired confidence. Houston had won Elliot's friendship, and by letters sent through Elliot directly to Aberdeen had secured the confidence of that minister. Anxiety with regard to a possible American annexation was expressed from but one direction. Elliot saw that there was probability or possibility of such action, and he urged it as a reason for British activity. It might well appear to Aberdeen, however, as merely an argument put 
forward to hasten the adoption of Elliot's scheme for Texas, and everything points to a sense of security upon Aberdeen's part. He felt that he was in control of the situation, and had no fear of American annexation, or at least he believed that there was no necessity for alarm and no fear of immediate danger from the United States.

In the midst of the flood of worthless books on America from the pens of English travelers there occasionally appeared one of notable merit, valuable today for its record of careful observation, and of contemporaneous importance because of the influence exerted by it upon its readers. Such a book was published in London in I842. The author, James Silk Buckingham, had journeyed through the Southern States in 1839-1840, and his descriptions of travel in America had a larger contemporary circulation than those of any other Englishman. ${ }^{20}$ His two volumes, entitled "The Slave States of America," appeared in London in 1842 , and the opinion that he there expressed had weight in official circles and with the British reading public. Slavery as an institution was, of course, Buckingham's keenest interest, and his book treats of it most thoroughly. An ardent abolitionist

${ }^{20}$ Buckingham was a man of some political importance, but was principally known for his radicalism and for his interest in social questions. As a newspaper editor in India he had been expelled for the vigor of his censures upon the abuses of government there. Returning to England, he was elected to the first reformed Parliament, from Sheffield. He was much in the public eye as a lecturer on temperance, and was always a bold critic of public morals. Three volumes on America, treating of the Northern States, had previously been published by him, and others, on the West, came out shortly after those on the South. 
himself, he found it difficult to listen with patience to what he considered the illogical arguments in defense of slavery met with throughout the entire South. Such reasons as all Southerners presented he could meet with the stolidity of an Englishman of fixed convictions, yet he saw no happy outcome for the abolition agitation. Believing firmly in the high moral ground upon which the institution was attacked, he yet directly stated that he did not believe that agitation would be of any use whatever in changing slave conditions in the Southern States. In his despair of bettering these conditions by agitation, Buckingham voiced not alone his own but the general opinion of all English travelers who went into the South and could see for themselves. And he further believed that a hopeless and useless continuance of British agitation might embitter the relations between Great Britain and the United States.

Buckingham's picture of Texas, its rapid development, and the substantial character of its population, was most interesting. He believed that the distinctly disorderly element of the earlier period was rapidly giving place to a solid and worthy community, and the future of Texas was rosy. He wrote that ambition for annexation in Texas was waning; that Texas feared the Northern States would never permit her entrance into the Union with slavery, while, as a slaveholding state, she would never consent to enter without it. In short, such was the difficulty of the situation that the result would be an independent state, rich, new, and powerful. How convincing such published statements were one cannot judge, yet the dictum of a book descriptive of a new and compara- 
tively unknown country would carry more weight and find readier acceptance than if concerned with more familiar ground. So little was known of Texas that any source of information was eagerly seized, and the probability is that the general public based its conclusions very largely on such books as those of Kennedy and Buckingham, while the government would depend to a great extent on official sources for its knowledge of conditions. Nevertheless, it is unlikely that the ministry itself would wholly ignore facts and sentiments presented so intelligently and with such unanimity of belief. Even with conservative allowance for prejudice and exaggeration, it is not unreasonable to suppose that these volumes had a certain influence on officials. The works of Buckingham and Kennedy, therefore, are really important factors in estimating what was English opinion at the time, and both these men had expressed a belief in the future greatness of Texas and in her importance to British interests. 


\section{CHAPTER VI.}

1843. The Robinson Armistice and the London Abolition Meeting.

The closing act of the year 1842 in relation to Texas was the refusal of Aberdeen to join with France and the United States in a triple intervention to be urged upon Mexico. Aberdeen had suggested as a substitute for this plan that the representatives of England and France should each urge upon Mexico the advisability of making peace, but that they should not act in concert. This proposal had been accepted by France, and instructions to act on behalf of his own country only were sent to Pakenham, while the French minister in Mexico received like instructions. To Pakenham the proceeding seemed quite useless, and upon consultation with the French minister it was decided to take no action at the time. In his report to Aberdeen Pakenham justified his apparent disobedience on the ground of the absolute inutility of the act, and he received Aberdeen's approval for withholding the matter from Mexico. ${ }^{1}$ It was unfortunate for the interests of Great Britain in Mexico that Pakenham at this juncture was recalled to London, and that Percy Doyle took his place. Pakenham was to be promoted to the ministry at Washington. While his own appointment to the United States was permanent, that of his successor was not, and in all probability Doyle was regarded

${ }^{1}$ F. O. Mexico, I6I, Pakenham to Aberdeen, February 24, I843. 
merely as a stop-gap until a suitable appointment could be made. Doyle himself, however, was ambitious for the permanent position, had no misgivings as to his capacity, and regarded himself as of full ministerial rank. It therefore fell to Doyle, unluckily, to conduct the delicate negotiation which came up in I843 looking toward an armistice between Mexico and Texas.

For the first three months of the year I843 Elliot in Texas was still firm in his adherence to the plan outlined in his earlier letters to Addington. Frequent letters in support of his great plan for a reorganized Texas were being transmitted, with increasing insistence on British advantages and an ever decreasing confidence in governmental sympathy as the months went by and brought no reply. It was true that mail facilities were disappointingly slow and inadequate in those days, and Elliot, comforting himself with all the possibilities of delays in transmission, still found great satisfaction in his picture of a Texas without slavery where British commercial advantages should be greatly extended. At all times he was keenly alive to the danger of annexation to the United States, and in his letters laid great stress upon such a possibility unless England could assist in securing peace promptly. ${ }^{2}$ In constant correspondence with Houston, the freedom and confidence of their intercourse is indicated in the boldness with which Houston outlined his ideas to Elliot. On January 24 Houston, writing from Washington, Texas, to Elliot, urged that England force Mexico to make peace, and that speedily. ${ }^{3}$

${ }^{2}$ F. O. Texas, 6, Elliot to Aberdeen, January 28, 1843.

${ }^{3} \mathrm{~F}$. O. Texas, 6 . Houston's original is enclosed in a letter from Elliot to Aberdeen, February 5, I843. 
He said: "There is a subject now mooting in Texas which it seems to me will appeal directly to Her Majesty's Government. I mean that of annexation to the United States. Some of our journals are much in favor of the measure. I find from the uncertitude of our situation that nine-tenths of those who converse with me are in favor of the measure upon the ground that it will give us peace. Upon this point of our national existence I feel well satisfied that England has the power to rule."

Houston further asserted in this letter that the whole of the United States was rapidly becoming a unit in favor of annexation, and that should annexation become a fact the territory included would mean not only Texas but the Bay of San Francisco and the Pacific Coast in general. $\mathrm{He}$ asserted that annexation would soon be the policy of both political parties in the United States. "Annexation is to be a question with the political parties and aspirants in the United States. My own opinion is that both parties will advocate the policy. To defeat this policy it is only necessary for Lord Aberdeen to say to Santa Anna, 'Sir, Mexico must recognize the independence of Texas.' Santa Anna would be glad of such a pretext. He could then say to the Mexicans-You see how I am situated. I cannot go to war with England, our last friend, with a probability of war with the United States and France."

According to American historians generally, the month of February, 1843, in which this very frank note is dated, marks a definite change of policy with Houston. In 1842 Texas took the initiative in two separate efforts looking to United States annexation, 
but without success. The historical inference has been that Houston, until February, 1843, was ready at any time to renew overtures, but that in that month he definitely dropped the plea for annexation, and embarked upon a policy in which Texas should no longer pose as a suppliant. This involved arousing the antagonism of the United States to Great Britain in order to force the United States to make overtures to Texas. ${ }^{4}$ It is impossible to find confirmation, however, for these hitherto accepted historical conclusions. An examination of the correspondence between Elliot and Houston at this period and in the months preceding and of Elliot's letters to Aberdeen does not indicate that February, 1843 , saw any change in Houston's plans. Referring to the earlier letters immediately succeeding Elliot's arrival, as well as to those of the winter following, it can be seen that Houston's point of view in February was equally his point of view in November of 1842 ; that Texan independence was his theme from the moment Elliot set foot in Texas; and that his desire for British intervention to secure peace had been repeatedly urged. Whether or not Houston was sincere in his desire for an independent Texas, he was at least perfectly steadfast and consistent in his plea for Elliot's support from the beginning of their intercourse. The importance of this lies in the fact that Houston's assertion to Elliot of his desire for an independent Texas was just as emphatic before he knew of Tyler's refusal of Texan overtures as after that refusal.

When the end of March brought no reply to his

- Reeves, IIg, cites the despatch of Jones to Van Zandt of February 10, 1843, indicating this policy, and says that it was a new policy. 
letters advocating a live British campaign in the affairs of Texas, Elliot began to be genuinely anxious. $\mathrm{He}$ was reluctantly forced to conclude that his letters had failed to interest Aberdeen in his plan, and he was much disappointed. While he still believed the abolition of slavery in Texas feasible, and still asserted that it would not be difficult to secure, he decided to shift the emphasis and to urge the necessity for the immediate exertion of pressure upon Mexico by England. Temporarily, then, Elliot was obliged to give up the rôle of philanthropist in order to emphasize the commercial interests of Great Britain and the necessity for action to prevent American annexation. In this connection he wrote long accounts of the practical abilities of the Texans, eulogizing their good qualities and making light of their crudities. ${ }^{5}$

These people are rough and wild, but their constancy and courage are admirable. I hardly know any more fearful and indeed humiliating subject of reflection than the comparative helplessness of our own poor English people, when we find them thrown amongst these scheming, enterprising, and it is most distressing to add, almost invariably much better informed persons than themselves. The truth is that the poorer classes of English people are broken in, or should I say broken dozen to do but one thing in the world ... in this country they make but sorry work of it in taming the wilds, compared with the American races. The training of our political and social mechanism (and my experience has taught me, military too) unfits men for rough uses and reverses. It must all work together perfectly smoothly and successfully, or it will hardly work at all. These strange people jolt and jar terrifically in their progress, but on they do get, and prosper too, under circumstances when our people would starve and die.

The first four or five months of Elliot's residence were spent in becoming adjusted, and his services had

${ }^{5} \mathrm{~F}$. O. Texas, 6, Elliot to Addington, March 26, 1843. 
been confined to the cultivation of friendly relations with Houston and Jones and to the reporting of conditions as he saw them in Texas. On March 29 Elliot had just learned of what came to be known as the Robinson plan, so called by diplomats at this time, which was intended to secure an armistice between Mexico and Texas as a forerunner of ultimate peace. The general outline and scope of the plan it is best to understand at the beginning, especially as much misinformation as to its origin has been prevalent. It derived its name from a Texan prisoner in Mexico, Robinson, who obtained an audience with Santa Anna, and reported to him that a large party in Texas desired reannexation to Mexico on terms of local self-government and nominal Mexican sovereignty. Santa Anna commissioned Robinson to make overtures along these lines to the Texan government, releasing his prisoner for that purpose; illness fell upon Santa Anna soon after, and nothing tangible came of the effort from the Mexican end. Meanwhile Robinson had arrived in Texas and informed Houston of Santa Anna's desire for an armistice. ${ }^{6}$

The statement has commonly been made that either

' J. W. Robinson was well known in Texas, having served as lieutenant-governor in 1835 . He had been captured by Mexican troops at San Antonio de Bexar in March, 1842, and sent to the city of Mexico. Robinson wrote to Santa Anna on January 9, I843, with the result. that he was given an interview and soon released. (Bancroft, XVI, 372:) Bancroft regards the whole matter as a mere ruse by Robinson to secure his liberty, but in Texas opinions were expressed both for and against his plan. See Niles' Register for April 15, I843, giving a letter from Robinson to the Galveston Times. The Times was contemptuous, but the Galveston Civilian approved the plan. 
Elliot or Doyle was responsible for this plan, and that they eagerly supported Santa Anna's efforts toward an armistice, even if they did not inspire them. Elliot's correspondence of this period absolves him, however, from all responsibility in the matter, and shows a distinct disinclination to offer his services in furthering it. $\mathrm{He}$ distrusted Santa Anna's genuineness in the matter, and in his report to Aberdeen so stated the affair that Aberdeen himself was not impressed, regarding it as too vague to be promising. Elliot's report of Robinson's scheme was extended to include comment and rumors of American annexation, and Aberdeen's reply, on May 18, treated of these, and not of the armistice. He wrote:-

With regard to the project for the annexation of Texas to the United States, which has formed the subject of some of your recent communications to this Office, Her Majesty's Government do not think it necessary to give you any Instructions at the present moment on that subject, further than to desire that you will assure the President of the continued interest which the British Government takes in the prosperity and independence of the State of Texas: and of their full determination to persevere in employing their endeavours, whenever they see a reasonable hope of success, to bring about an adjustment of the differences still existing between Mexico and Texas, of which they so much lament the continuance. $^{\text {? }}$

Later in the same month, May, 1843, Pakenham arrived in England, and personally presented at the foreign office despatches he had prepared in Mexico and addressed to Aberdeen, bearing upon the matter of the projected armistice. His information was based upon an interview with Santa Anna in which the Mexican president outlined the Robinson plan as previously

'F. O. Texas, 6. 
stated, but this interview had been followed by Santa Anna's illness, during which Pakenham left Mexico. There had been no details, and Pakenham made his report without comment, save to say that he believed the Texans were truly weary of independence, and that a few months would see Texas annexed either to the United States or to Mexico. Pakenham's presentation of the Robinson plan did indeed insure sufficient interest on Aberdeen's part to inspire fresh instructions to the British representatives both in Texas and in Mexico. In those sent to Elliot ${ }^{8}$ he expressed his conviction of the genuineness of Santa Anna's offer and his desire to see a favorable outcome. He argued that the offer meant virtual independence, and that a mere matter of technical sovereignty ought not to prevent acceptance by Texas. At the same time he was very careful to instruct Elliot that Great Britain would not make herself in any way a party to this transaction or incur any responsibility in regard to it, although she was perfectly willing to use her good offices " in an entirely neutral and impartial sense, in order to bring about a peaceful and equitable adjustment of the differences existing between Texas and Mexico." But while instructing Elliot to urge upon Texas an acceptance of the Robinson plan, Aberdeen instructed Doyle, now acting as chargé d'affaires in Mexico, that the plan did not go far enough, and that Mexico's best policy would be to make a complete and full acknowledgment of Texan independence at once. ${ }^{9}$ In this instruction Aberdeen for the first time brought up the question of abolition. He wrote, "It may

${ }^{8} \mathrm{~F}$. O. Texas, 6, June 3, 1843 .

-F. O. Mexico, I60, July I, I843. 


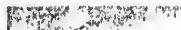

deserve consideration whether the abolition of Slavery in Texas would not be a greater triumph, and more honourable to Mexico, than the retention of any sovereignty merely nominal."

Aberdeen's purpose is plain. He was urging upon each state greater concessions than either had been willing to make, in the hope that a compromise might be effected which would result in a real conciliation. It may be taken for granted, however, that Aberdeen did not expect Texas to consent to any arrangement which should not explicitly stipulate a recognition of her independence.

In the meantime, Elliot, in a long interview with Houston, had gone over again the whole bearing of the Robinson plan, and Houston had raised many objections to it. $\mathrm{He}$ argued most vigorously against Santa Anna's proposal for an armistice, and protested against its being given English support. The report of this conversation is embodied in a letter which Elliot wrote to Pakenham, on April I4, while under the impression that Pakenham was still in Mexico. ${ }^{10}$ On May I3 Houston wrote from Washington, Texas, to Elliot, again urging upon him the only course which could be effective in bringing peace to Texas. The Mexican proposal of an armistice would accomplish nothing, and Texan independence would be assured only through immediate recognition. England could impose this course upon Mexico and thus eliminate the question of American annexation. Houston impressed upon Elliot the ever increasing difficulties which the annexation problem presented to him, especially as the desire of Texas to be annexed seemed ${ }^{10} \mathrm{~F}$. O. Texas, 6 . 
only less than the determination of the United States to annex. Elliot held this letter for some time before transmitting it to Aberdeen, and on June 8, when he did finally send it, expressed the greatest anxiety that it be kept with complete secrecy. ${ }^{11}$ His reply to Houston contains a statement regarding slavery which, from the correspondence, seems totally irrelevant; nevertheless, Elliot pledged his word that at no time had he received any instructions to urge abolition upon the Texan government, and "that the subject of slavery in Texas had never been mentioned to me in any despatch from Her Majesty's Government, or by word of mouth." It does not appear from Houston's letter why this assertion should have been drawn from Elliot. It may have resulted from a conversation between the two men rather than from written correspondence.

In the interchange of letters between Houston and Elliot, as well as in the interviews to which the correspondence refers, there seems to be abundant proof that Houston first opposed English efforts to force the armistice. In his very first letter to Elliot (reported to Pakenham in April) Houston begged Elliot's good offices to discourage any British backing for Santa Anna's plan. Again in May his letters expressed anxiety for fear of United States annexation, to avert which he asked Great Britain to drop the proposal for armistice and to force Mexico to a recognition of Texas. From his first knowledge of the'projected truce, he steadfastly demanded that England repudiate the plan. Nevertheless, it has been generally believed that the negotiations connected with the Robinson plan were only another instance of clever ${ }^{11}$ F. O. Texas, 6. 
strategy and doubtful sincerity on Houston's part. It has been supposed that, instead of being opposed to the armistice, he really encouraged it, thereby gaining a weapon to hold over the United States. On this hypothesis, Houston was only playing with England, and hoping for such advances from that country as should the sooner bring the United States to terms with Texas. Such an interpretation is at least based upon wrong premises, i. e., that English agents suggested the project, and that Santa Anna "was prevailed upon by Doyle" to permit the overture. ${ }^{12}$ It is true that this was the impression given out by Texan officials. The plan had originated with Santa Anna, neither Doyle nor Elliot was enthusiastic over it at first, and both acted with much hesitation..$^{13}$

Early in June Elliot received Aberdeen's first official instructions relating to the Robinson plan, and obeyed them by presenting a formal document which advised the Texan government to concede Mexican sovereignty and thus secure the benefits of practical independence. ${ }^{14}$ Upon the same date, however, a personal

${ }^{23}$ Reeves, 122.

${ }^{13}$ The theory of Reeves regarding Houston's activities here is that Houston was fortunate in being able to make use of this armistice scheme. It is quite true that later he did seem to make use of it in the sense indicated by Reeves. The fact, however, that when the scheme first came up Houston was distinctly opposed to it and anxious that England should not support it is fairly good proof that Houston's use of the scheme was rather the result of later opportunity and, more probably, of pressure brought to bear upon him, than that the whole plan was initiated by him. Here again we have seemingly excellent evidence of Houston's sincerity in his desire for independence. For Reeves's interpretation, see his Diplomacy under Tyler and Polk, II9 seq.

${ }^{14}$ F. O. Texas, 6, Elliot to Doyle, June 21, I843. 
letter to Doyle expressed Elliot's conviction that the only possible solution lay in the immediate recognition by Mexico of Texan independence. In defence of this belief he availed himself of all of Houston's arguments, and cited his facts from conversations with the Texan president. The first formal document which he had presented to the Texan government was followed on July 24 by another in the same vein, ${ }^{15}$ in which he did not advise the concession of Mexican sovereignty but argued its advantages to Texas. That Elliot's expressions to Doyle should be so at variance with the expressions and intentions of his official letter to the Texan government betrays no disloyalty to his chief, but indicates confidence that Aberdeen's instructions were purely perfunctory, and that the foreign office had no expectation that such a plan would be acceptable to Texas. At the Mexican end the armistice negotiations were delayed by Santa Anna's illness. Upon his recovery he sent for Doyle, and at their first interview told him of the plan as he had outlined it to Pakenham. As a result of the interview, Doyle consented to suggest an armistice to Elliot and to ask him to put the matter officially before Houston. ${ }^{16}$ Lacking definite instructions from Aberdeen, however, Doyle felt the delicacy of his position and undertook the negotiation with considerable hesitation. He acted in the matter rather as an agent for Santa Anna than as a British diplomat, and his despatches, which give with detail the steps of the negotia-

${ }^{25} \mathrm{~F}$. O. Texas, 6, Elliot to Jones.

${ }^{16} \mathrm{~F}$. O. Mexico, 162, Doyle to Aberdeen, May 25, I843. Houston had of course heard of the plan long before this and told Elliot of it. 
tion, show that he was really a middleman in the whole transaction. He neither originated nor urged it, but, animated by an ambition to be as serviceable as his predecessor, he undertook the part assigned him by Santa Anna, finding his justification in the fact that it looked toward a Mexican-Texan peace, and hoping his action would win the approval of Aberdeen.

Houston's action on the armistice antedated the receipt by Elliot of instructions in regard to the matter, and came as a result of Doyle's agency and the certainty that some step would have to be taken. On June $\mathrm{I} 3$ he proclaimed a cessation of hostilities and appointed commissioners to meet those from Mexico. This was done in spite of the fact that it seemed to lead up to an inevitable dead-lock. It was popularly known that Mexico would consider no arrangement with Texas which did not recognize Mexican sovereignty. There was also the perfectly understood fact that Texas would repudiate any possible scheme which implied an acknowledgment of such Mexican sovereignty. This impossible situation has led historians to believe that Elliot was here again merely a tool in the hands of Houston to arouse anti-British sentiment in America. It must be remembered, however, that Elliot's statement to the Texan government, made a little later, was but a formal act in obedience to Aberdeen's first instruction concerning the Robinson plan; again, that Elliot personally was convinced that back of Aberdeen's formal instruction was a real intention to force upon Mexico a recognition of Texas; and further, that the intimate relations existing between the two men presupposes Houston so deeply in Elliot's confidence that he would read England's pur- 
pose in this instruction quite as Elliot did. If, as Elliot believed, Aberdeen intended to force Mexico to peace measures despite all Mexico's protestations to the contrary, Houston, who had urged such action from the beginning of his intercourse with Elliot, and shared Elliot's point of view, should be acquitted of charges of duplicity in accepting the situation.

The communication which Santa Anna requested Doyle to make was sent to Elliot in due form in May, and was followed by Houston's proclamation of armistice on June I3, already referred to. That proclamation was forwarded to Doyle, who transmitted it to Santa Anna. It was accepted, and General Woll of the Mexican army was notified on July I 2 to cease all preparations for hostilities. With this apparent acquiescence, Santa Anna gave no sign of yielding an inch in the matter of the nominal sovereignty over Texas, and again insisted that a final peace would be obtained only through a Texan acknowledgment of Mexican sovereignty. Doyle regarded this insistence without anxiety, supposing it to arise from the necessities of the political situation in Mexico. ${ }^{17}$

Information in regard to this much discussed armistice reached the United States representatives only after Houston had determined to act. It was in June that Anson Jones, the Texan secretary of state, told Murphy, the United States agent in Texas, of the plan as given and of Houston's decision in regard to it. Through Murphy, who was greatly disturbed over the whole affair, an account of the matter reached Upshur, the American secretary of state, and of course ${ }^{17}$ F. O. Mexico, 163, Doyle to Aberdeen, July 30, I843. 
President Tyler. The effect of this news in United States official circles was stirring, though an account of its receipt and comment upon it must properly be deferred until later.

Thus by the middle of 1843 steps had been taken which appeared upon the surface to tend toward the accomplishment of a permanent peace. At this point, in prder to comprehend the attitude and instructions of the English government, it is necessary to give attention to affairs in London, where events largely affecting the progress of the armistice project were occurring. By this time Aberdeen was really keenly interested in the negotiation, though he had shown so much indifference when it first came up. After Elliot's first letter, Pakenham's appearance and communications had really impressed him with the opportunity the plan offered, and when, in July, a committee of Texans and Americans convened in London to discuss the abolition of slavery in Texas, Aberdeen's interest was fully aroused. The committee meeting followed shortly upon a general antislavery convention in London, where British abolition sentiment as well as abolition sympathy from all quarters found free expression. Among the delegates (though in no sense an accredited delegate from Texas) was a certain $\mathrm{S}$. P. Andrews, a lawyer from Houston, Texas, reputed a strong abolition agitator. Andrews, it was reported, made a proposition to Aberdeen that "Great Britain should advance a loan to Texas to be applied to the purchase and emancipation of Texas slaves." ${ }^{18}$ The matter appeared in Aberdeen's instructions to Doyle, on July $3 \mathrm{I}, \mathrm{I} 843^{19}$ In this instruction Aberdeen re-

${ }^{18}$ Reeves, 126.

${ }^{10}$ F. O. Mexico, I60. 
ferred to the meeting of the committee, which he called the "Tappan" committee, and transmitted to Doyle the answer of the foreign office to Tappan: $:^{20}$ "You will perceive that Mr. Tappan is informed in that letter that if the State of Texas should confer entire emancipation on all persons within its territory, and make that decision permanent and irrevocable, H. M. Govt. would not fail to press that circumstance upon the consideration of the Mexican Government as a strong additional reason for the acknowledgment by Mexico of the independence of Texas."

Aberdeen went on to state that he had no assurance that Texas would undertake to abolish slavery, but that the armistice made it seem probable that peace was near; the subject in fact was one so close to the heart of the British people that Doyle must not fail to press it upon the Mexican government. He wrote that he was "satisfied that it might be a point well worthy of the favourable consideration of the Mexican Govt., whether it would not be wiser and more consonant to their true interests, and even to their dignity, to waive the vain and objectionable condition of nominal supremacy over Texas which they have included in the propositions submitted by them through Mr. Robinson to the Govt. of Texas, and rather to substitute for it that of the absolute abolition of the principle of

${ }^{20}$ There were four brothers Tappan resident in the United States, all interested in the abolition movement, but it has been impossible to determine with certainty which one of them was received by Aberdeen. Arthur Tappan had the leading reputation as an abolitionist, having founded the New York Emancipator in 1833 . He was also one of the founders of Oberlin College, was president of the Anti-Slavery Society, and was much hated by southern advocates of slavery. 
slavery, and properly regulated emancipation of slaves in Texas.

"H. M. Govt. desires that you should press this point earnestly on the attention of the Mexican Govt."

It will be recalled that in an earlier communication in regard to the Robinson plan, on July I, Aberdeen had directed Doyle to press upon Mexico the question of slave emancipation in Texas. His later and more definite instruction may reflect the more immediate influence of the abolition convention, but it shows the temper of the British foreign secretary and, in some measure, the temper of British subjects. If Great Britain could prevail upon Mexico to take the initial step leading to abolition in Texas, the triumph would be great, no matter through what agency it was brought about. ${ }^{21}$

Aberdeen's meeting with the abolition committee was no secret, and it is not surprising that it created great excitement. To Americans or Texans, to abolitionists or slaveholders, it was a matter of moment that the director of English foreign policy should busy himself with any organization looking toward emancipation of slaves anywhere in the New World. Reports of his action, many of them untrue or exaggerated, were, of course, immediately sent out from England to the

${ }^{21}$ In May, 1843, the southern newspaper press got hold of rumors in regard to Elliot's grand scheme for a reorganized Texas and for the abolition of slavery. The matter appeared in the New Orleans Bee, and that paper became much exercised over "abolition plots," making a vicious attack on both Elliot and Houston. A letter to the Bee from a Galveston correspondent stated that Elliot had no share in the scheme, but it is interesting to note that the rumored "plot" followed exactly the essentials of the plan advocated by Elliot in his letters to Addington. Niles' Register, June 10, I843, p. 23I. 
countries most nearly concerned. In both the United States and Texas they were received, naturally, with popular indignation, while in each case the government withheld its judgment until it should have official information.

An American, Duff Green, a general in the United States army and a Southerner, was in England at the time, and promptly made use of an opportunity where British interference could be charged. $\mathrm{He}$ it is who is credited with writing to Upshur upon the matter and suggesting that England's abolition plans be used to arouse the friends of American annexation. With Ashbel Smith, the Texan representative in England, however, there was no anxiety to make political capital out of the episode, and he immediately took steps to learn the truth of the various rumors, in order to report correctly to the Texan secretary of state. In a conference with Aberdeen he stated plainly that Texas would never for a moment consider the abolition of slavery, and on August I he addressed a note to Aberdeen intended to record the objections of Texas to any such plan:-22

In making the present communication the Undersigned begs to disclaim intimating the opinion that there exists any disposition on the part of Her British Majesty's Government to interfere improperly in the affairs of Texas, an opinion which would be wholly inconsistent with the frank and friendly tone of his Lordship's remarks in the interview the Undersigned had the honor to hold with his Lordship on this subject; nor does the Undersigned wish or expect to interfere with the liberty of British subjects to discuss the matter in question or any other matter, but his object is to place on record the explicit disapproval by the Texian Government of all proceedings having for their object the abolition of slavery in Texas.

${ }^{22}$ F. O. Texas, 8. 
While Smith's note states very clearly that British interference with a Texan institution would never be tolerated, it diplomatically ignores the possibility that Aberdeen could act improperly in the matter. On the day previous, however, he had written to Anson Jones an account of the interview with Aberdeen, in the course of which he had asked if it were true that Great Britain was preparing to secure the abolition of slavery in Texas by making a money compensation to the slaveholders. "His Lordship replied in effect: That it is the well known policy and wish of the British Government to abolish slavery everywherethat its abolition in Texas is deemed very desirable. ... He added that there was no disposition on the part of the British Government to interfere improperly on this subject, and that they would not give the Texian Govt. cause to complain. He was not prepared to say whether the British Govt. would consent hereafter to make such compensation to Texas as would enable the slaveholders to abolish slavery. The object is deemed so important, perhaps he might, though he would not say certainly." 23

While the exact wording of Smith's report to Jones is in strict agreement with his official communication to Aberdeen on August I, the two documents certainly differ in emphasis and in the impression conveyed. The note to Aberdeen emphasizes Smith's perfect understanding that British policy intends no improper interference in the affairs of Texas. The report to Jones lays stress on Aberdeen's inclination to help, if not to "interfere," in securing the abolition of slavery, and the very uncertainty of Aberdeen's in-

${ }^{23}$ Quoted by Reeves, I27. 
tentions, as noted in the report, would naturally tend to increase 'American suspicions. The reason for the difference of emphasis in these two documents was probably Smith's own uncertainty as to British plans, rather than any purpose to magnify British antislavery activities in Texas.

Duff Green's letter, obviously prepared to arouse anti-English sentiments to the utmost, laid great emphasis on England's interest in abolition, and even went so far as to state that the project of a loan noted in the conferences between Aberdeen and the antislavery committee referred also to a moneyed support to be given in order to prevent the annexation of Texas to the United States. ${ }^{24}$ Such a statement was entirely unwarranted, and nothing in Aberdeen's statement to Smith or in his report to Doyle on the Tappan committee can be found to justify it. There is indeed no evidence that he ever really considered the project of using money to purchase abolition in Texas. Green's report when it was finally made public, accomplished its purpose and aroused the expected excitement in the United States. The attitude of the British government in this matter of abolition was of great interest to the people on both sides of the Atlantic. On August I8 it was the theme of a debate in Parliament, when Lord Brougham interpellated the ministry on the subject of British interests in Texas. $\mathrm{He}$ asserted that Mexican recognition of Texas might be used to force abolition on that State, and that this, in turn, would react against slavery in the United States. 'Aberdeen's reply was an evasion rather than an explanation, and he refused to present the papers called for

${ }^{24}$ Reeves, 127. 
by Brougham. He did say, however, that this refusal " did not arise from indifference, but from quite a contrary reason." ${ }^{25}$ Such treatment of the question could not bring satisfaction in any quarter. Indeed, both friends and enemies of Texan independence were left to believe that Great Britain was really preparing some measure to bring about abolition in that State. ${ }^{26}$

Upon the receipt in the United States of the various rumors involving British interference, formal instructions to investigate and report upon the matter were sent to Everett, the American minister in London. Everett was to obtain from Aberdeen a statement relative to his conference with the antislavery committee, and, if possible, to get from him an announcement of British plans. In accordance with these directions, Everett secured an interview with Aberdeen, and came away from it convinced that the whole affair was a mare's nest, and that Great Britain had no intention whatever of stirring the subject of slavery in Texas. On November 16 Everett reported to Upshur :-

${ }^{25}$ Hansard, 3d Ser., LXXI, 9I7.

${ }^{28}$ Von Holst, II, 624 seq., correctly states that this reply by Aberdeen naturally created suspicion in America, even though the suspicion itself may not have been well founded. With such evidence as was at his command, Von Holst concludes that there was no real ground for believing that Great Britain was pursuing any active policy looking toward abolition. He is careful, however, to state that Great Britain's previous activities in colonial affairs and her well-known interests in Mexico and Central America, as well as her general opposition to the expansion of the United States, all tended to justify the suspicions of Tyler and Calhoun. In Von Holst's opinion, Great Britain suffered here for her previous sins. 
The subject of domestic slavery was never so much as mentioned or alluded to by the British minister to the government of Texas, except to disclaim in most emphatic terms any intention on the part of England to interfere with it here. Indeed, that constituted no part of the policy of that far reaching nation. She might be willing to tickle the abolitionists (a somewhat venomous but very respectable or influential class of her citizens) but had no idea of going in a crusade with them to abolish slavery in Texas, or anywhere else. Her Texas policy was to build up a power independent of the United States who could raise cotton enough to supply the world; of which power slavery would be a necessary element. And this not primarily to injure the United States, but to benefit herself, not from enmity to Brother Jonathan, but love to John Bull, and so with France. ${ }^{27}$

Indeed, the substance of Everett's report was that Aberdeen explicitly denied ever having taken up with Texas the matter of abolition. This official report to the United States thus acquits Great Britain of improper interference, and doubtless Everett expected it to allay suspicions of Aberdeen. In Texas also it was necessary that Aberdeen be exonerated from suspicion of a direct effort to influence affairs in that State, and the foreign office immediately put itself upon record in the matter. As a result of a conference between Smith and Aberdeen, following the parliamentary debate of August I8, Aberdeen transmitted to Smith a definite reply to his communication of August I. This note was writen on September II, I843. ${ }^{28}$ In it Aberdeen stated that the British government had no wish to interfere with Texas. "Nothing can be further from their intention than thus to interfere in the internal affairs of Texas. But at the

${ }^{27}$ Cited by Reeves, I33, from the official correspondence of Anson Jones.

${ }^{28}$ F. O. Texas, 8. 
same time that the Undersd makes this declaration, he believes that Mr. Smith is fully aware of the continued anxiety of H. M. Govt. to see Slavery abolished, not only in Texas, but in all parts of the World: and it is a matter of no surprise to the Undersd that private Individuals, who are impressed with the same feelings, should exert every effort in their power to attain an object so desirable."

While both Aberdeen's reply to Everett and his note to Smith disclaimed any intention of interfering in Texan affairs, they are both stamped with the hope of securing abolition in Texas. That Aberdeen definitely hoped to see abolition an accomplished fact in Texas is certain, and so far as his personal sentiments in the matter, and, indeed, the general sentiments of the great majority of the English people, are concerned, he left no one in doubt at any time. He took great care always to emphasize the sincere British interest in the world-wide abolition of slavery. While avowing his deep personal sympathy with the cause of abolition, his emphatic disclaimer of active or official interference in Texas to bring about a result for which all Englishmen hoped, served to call attention to his fine sense of the limits of international prerogative. His denial that Great Britain had ever suggested to Texas any plan looking toward emancipation of the slaves was convincing to most people, and his differentiation between personal sentiments and national privilege quite effectually blinded the public to the fact that any other measures might be under way to accomplish the main purpose. Aberdeen's instructions to Doyle, however, show that there was a specific project on foot intended to achieve indirectly a result which could not 
otherwise be reached. Nevertheless, both Smith and Everett accepted Aberdeen's explanations and denials, and neither of them at first suspected reservations or other means to attain British ends.

Thus there was a basis of truth in all the various American suspicions of British policy. It is customarily stated that the substance of the American plan in the spring of 1844 was to urge that "Texas must be annexed as a measure of self protection to the United States against the encroachments of Great Britain " in the commercial field, and that "Texas must be annexed to the United States in order to protect the slave interests of the Southern States, so jeopardized by Great Britain's advocacy of abolition in Texas." ${ }^{20}$ These two points are exactly the ones upon which Kennedy and Elliot had centered most of their attention in outlining a plan of British action. To neither of these agents had Aberdeen made any reply. If their suggestions impressed him at all, he used them only in instructions to Doyle, whose directions were that Mexican recognition be made contingent upon abolition in Texas. Yet, after all, this was only an effort to secure in roundabout fashion what Elliot advocated in Texas. In his purpose and in his mode of procedure there was, of course, nothing dishonorable in the conduct of Aberdeen, and nothing for which the British government could be called to account in case it were perfectly understood that she was attempting to prevent the annexation of Texas to the United States. More than that, also, such a policy at this time was perfectly consistent with an honest conviction in Aberdeen's mind that to prevent Texan

${ }^{29}$ Reeves, ${ }^{2} 28$. 
annexation was in reality a kindness to the United States itself. The difficulty in the whole matter is, however, that while Aberdeen was pursuing this policy of preventing the annexation of Texas and at the same time attempting the abolition of slavery in Texas, he was denying accusations of Calhoun which charged him with precisely this line of action. Great Britain had a perfect right in defense of her own interests to oppose the expansion of the United States. She also had a perfect right to hope for the abolition of slavery everywhere, and to use her influence in securing it in a new state. Calhoun said that England was making efforts to prevent United States expansion, and that England was also attempting to further abolition in Texas and in America. Both of these statements Aberdeen denied, or at least he denied that British policy had gone farther than an expression of a philanthropic interest. If the matter were summed up as a straightforward contest for power between Great Britain and the United States, then in the light of present-day judgments both the methods and the aims of British policy were more honorable than were those of the United States. But in fact the ministry of Great Britain denied the existence of such British policy, and in this denial the judgment of history may discover a justification for the extreme suspicion of American statesmen. ${ }^{30}$

${ }^{80}$ It should be borne in mind, also, that those American statesmen who were most interested in the annexation of Texas, and first of all Calhoun, were conscientiously convinced of the justice of the institution of slavery, and were, therefore, acting under what were to them conscientious motives. This was certainly not true of all who favored the annexation of Texas, but there can be no question that it was 
The connection between the agitation of abolition ideas in London and diplomatic activities in Mexico and Texas was established when, on August I4, Doyle informed Santa Anna of Houston's acceptance of the armistice and his appointment of peace commissioners. Doyle, in presenting the information, urged that Mexico abandon the idea of retaining sovereignty over Texas. $^{31}$ His action was the result of Aberdeen's instruction of July $\mathrm{I},{ }^{32}$ which antedated the conference with the antislavery committee, the later instruction in which Aberdeen reported the interview with Tappan not having been received. At the same time that this later instruction was sent to Doyle, July 3I, a copy of it was forwarded to Elliot, ${ }^{33}$ together with an account of the meeting with the Tappan committee. Elliot was rejoiced, finding in these new instructions the probable realization of his dreams. He was wholly delighted, and he jumped to the conclusion that Aberdeen had finally awakened to the necessity for prompt action and intended now to force Mexico to make peace. His first impression was that the plan could

true of Calhoun. The fact is not necessarily honorable to him, but the conviction under which he labored should have been remembered by those who at the time never failed to impute evil to him. The very openness of the assertion, first by Upshur and Tyler, and later by Calhoun and Tyler, that Great Britain was planning the abolition of slavery in the United States, and that this was a just ground for American anger at Great Britain, indicates the moral sincerity of all three men. They believed in the institution of slavery, otherwise they would never have been so foolish as to cite a British attack upon that institution as the ground for a prompt annexation of Texas.

${ }^{81}$ F. O. Mexico, 163, Doyle to Aberdeen, August 29, 1843 .

${ }^{22}$ See before, p. 130.

${ }^{23}$ See before, p. 137 . 
be carried through, but that it must be put into immediate operation. He wrote to Aberdeen that the "proposal of Mexico to acknowledge the independence of Texas upon the condition to which your Lordship has adverted" would prevent any new slaves being brought in, and would quickly result in the extinction of slavery. ${ }^{34} \mathrm{He}$ also dilated upon the great advantages to England. "If the principle of free labor can be established here, what with the opportunity of procuring labor from Mexico, and by immigration from other quarters, and the increasing supply and improvement of the staple from India, there would very soon be an end of the remunerative production of Cotton by Slave Labor in the United States." With free labor would come free trade. Elliot felt that the American protective system was doomed to a speedy death, and the far-reaching effect of the suggested Mexican ultimatum for peace he could already see. Ten days later he wrote a long letter to Doyle, sending it by one of the Texan commissioners of armistice. In this Elliot outlined in bold fashion the objects to be labored for:- ${ }^{35}$

I trust that Mexico will be true to the great cause of humanity and to Itself, on this momentous occasion. The mere announcement of their just and honorable determination that a land which was free under their rule should not be turned into a Pen of Slaves for the convenience of persons possessing such property in the exhausted Slave States of the North American Union would of itself be a very important step towards the establishment and security of the due and needful weight of Mexico in the affairs of this Continent. They have but to signify that the sine qua non conditions of the acknowledgment of Texas by Mexico are decided and approved

थ F. O. Texas, 6, Elliot to Aberdeen, September 30, 1843 .

${ }^{85}$ F. O. Texas, 6, October Io, 1843 . 
measures for the early and final disappearance of slavery here, and formal adherence to the declaration of Mexico that the Independence is recognized and understood to be complete, whilst Texas remain a Separate Nation, but of non effect in the case that it should annex itself to any other Country, without the consent of Mexico.

It will be seen that Elliot's enthusiasm had quite carried him off his feet, and indeed his definite formulation of a program for Mexico goes much farther than has generally been supposed; yet it is to be remembered that in thus writing to Doyle he merely expressed his own desires, and that this letter had no official significance. The query at once arises whether Elliot may not have had some private authority that encouraged him in making these sweeping generalizations. There is no evidence whatever to confirm any such suspicion. Moreover, his action here is entirely in character; a dreaming intriguer, political theorist, and philanthropist, he suddenly felt himself within reach of the realization of long-cherished ideals, and he lacked the statesman's poise. His diplomatic responsibilities were lost sight of in his personal elation, and he was merely voicing his personal opinion.

While British influence in Mexico and Texas was being exerted toward peace in these countries, by way of abolition if possible, every effort was made in the United States to find out the true condition of affairs. Upshur, on August 8, had written to Murphy, the American representative in Texas, sending him the contents of the Duff Green letter, and asking for information. Murphy in reply was confident that there was no need of alarm about British plans for abolition in Texas, and advised Upshur not to use the abolition cry against Great Britain, but to base his attack on 
British policy upon the ground that it was attempting to secure from Texas a consent to reannexation to Mexico. This, Murphy wrote, could be consistently assailed as a step backward in civil government, religion, and political liberty. ${ }^{36}$ Murphy's unique suggestions were, however, ignored by Upshur, who preferred rather that Great Britain should answer to the charge of British interference in the institution of slavery. The American offer of an annexation treaty followed. On October 31, r843, Elliot wrote to Aberdeen, stating that Houston had shown him a despatch from the Texas agent at Washington, Van Zandt, giving the outlines of that offer. ${ }^{37}$ Houston expressed himself as greatly disturbed, and he wished Elliot to assure Aberdeen that if Mexico would speedily recognize the independence of Texas, the United States offer of annexation would be declined. “Her Majesty's Govt. might rest assured that with the Independence of Texas recognized by Mexico, He would never consent to any treaty on this project of annexation to the United States, and He had a conviction that the people would sustain him in that determination. He had formerly been favourable to such a combination; But the United States had rejected the proposals of this Country in its time of difficulty; neither was the subsequent conduct of that Government calculated to induce the Government and people of Texas in this mended state of things, to sacrifice their true and lasting advantage to the policy of party in that Country." Thus Elliot quoted Houston and expressed conviction in his sincerity; yet, in his reply to Houston himself

${ }^{36}$ H. R. Ex. Doc. No. 27I, 28th Cong., Ist sess.

${ }^{87}$ F. O. Texas, 6. 
he was much more cautious than usual, merely stating that he had no instructions as to British policy toward any projected American annexation.

Elliot was in fact surprised and perhaps chagrined at the American offer to annex Texas. While clamoring for British action to forestall annexation, and even fearing that the Texan public still favored an American connection, he had not considered the possibility of an offer from the United States, and he was therefore greatly disturbed. So far as Elliot was concerned the unexpected had happened. His only comfort lay in the non-committal attitude of Texas and the evident intention of Houston to postpone action. Van Zandt was instructed to inform Upshur that Texas would consider the question of annexation only when the United States Senate should act and some definite proposal should be made to Texas. Elliot felt, however, that matters were in a critical state. Unfortunately, just at this juncture he fell ill, and had to go to New Orleans to consult a physician. While there he found mental relief in some social contact with Henry Clay, whom he met for the first time. Clay's assurance that the United States Senate would unquestionably block any scheme looking toward Texan annexation brought great satisfaction to Elliot's troubled mind, and helped to restore the confidence and hope which had so recently been shaken. ${ }^{38}$ The year I843 thus closed with Elliot in New Orleans, and Texas waiting for action on the part of the United States.

In Mexico, also, there was a similar cessation of diplomatic activity. Here, however, the cause was a ${ }^{23}$ F. O. Texas, 6, Elliot to Aberdeen, December 3I, 1843 . 
personal quarrel in which Doyle had become involved with the Mexican government. After the armistice negotiations were begun it did not seem possible for either Doyle or Elliot to be of much service in the affair. In the final result they counted for nothing, but the armistice was continued until July of $\mathrm{I} 844$. Immediately after Doyle had successfully carried through his part of the negotiation he was forced to report to Aberdeen a rupture of diplomatic relations with the Mexican government, occasioned by very nearly an exact repetition of the flag incident in the time of Pakenham. It involved an altercation with Mexican officials at a public ball, a demand by Doyle that an English boat flag, exhibited among a group of Texan "trophies taken in war," should be removed from the wall, and a withdrawal of Doyle and all the English present when the demand was refused. Pakenham was more fortunate, however, in the former incident, for he succeeded in getting the flag and taking it away. Doyle's position was more humiliating, as he had to leave the flag hanging and demand its restoration to him after he had left the ball. The affair occurred on September 28, and created so much public excitement that war with England came to be talked of as a possible result. ${ }^{39}$ Doyle's dignity demanded the restoration of the flag before he should resume relations with the Mexican government, while the government refused the flag to any demand save that of the ${ }^{30}$ The story of the flag incident is in F. O. Mexico, I64, Doyle to Aberdeen, September 29, I843, and F. O. Mexico, 165, Doyle to Aberdeen, October 30, I843. It is pretty evident that Doyle had been reading Pakenham's correspondence, and felt that he must follow Pakenham's example. His misfortune was his inability to capture the flag. Failing that, he thought his only alternative was to sever diplomatic relations. 
British foreign minister. Mexico made an official explanation to Great Britain through its representative in London, and Aberdeen accepted that explanation, and ordered Doyle to resume diplomatic relations. At nearly the same time Bankhead was appointed to the post of minister at Mexico, and was somewhat hurriedly despatched to that point. At the time, with the armistice in effect and negotiations at a standstill between Texas and Mexico, Doyle's conduct here had no immediate bearing on affairs. It will be seen later, however, that this unfortunate incident was not without influence when the new minister entered upon his duties. Upon Bankhead's arrival in Mexico there was renewed hope in England of establishing a permanent Mexican-Texan peace, but the inevitable result of the Doyle rupture had so far weakened British influence in Mexico that Bankhead's task was much more difficult. Aberdeen unquestionably felt that for a time Mexico must be treated with the greatest delicacy if British influence were to be maintained, and Bankhead's whole conduct for the first few months after his arrival in Mexico was apparently inspired by excessive consideration for the Mexican government. But for the last months of I843, and until Bankhead's arrival, Great Britain was without influence in Mexico. ${ }^{40}$

${ }^{40}$ In his desire to pacify Mexico, Aberdeen even intermitted for a time the customary urging that Mexico pay her debts to British merchants. This irritated the merchants, and they joined in representations to the foreign office, lauding Doyle's action in the flag affair as necessary if British honor were to be upheld. F. O. Mexico, I7o. 


\section{CHAPTER VII.}

I844, January to June. The Calhoun-Pakenham Correspondence. 'Aberdeen's Plan to

Prevent Annexation.

The year I844 witnessed England's most direct effort to prevent Texan annexation to the United States, and in the early months the outlook for ultimate success seemed promising. Early in the year Elliot twice wrote to Aberdeen that any immediate danger of annexation was over, ${ }^{1}$ and his letters evinced his now restored confidence in the probabilities of peace and independence for Texas. He assured Aberdeen that the president of the Texan Republic was just as anxious as ever to maintain the independence of the State. Shortly after this, Elliot was compelled by the illness of his child to leave Texas again, and save for a brief return in the month of April he was not present at his post until late in the year. He journeyed to Virginia, and there, in the vicinity of Washington, was able to be in close touch with Pakenham, the new British minister in Washington, and could keep himself informed of the events at the United States capital. ${ }^{2}$

${ }^{1}$ F. O. Texas, 9, Elliot to Aberdeen, January 15 , and February 17, 1844.

${ }^{2}$ Copies of all the important correspondence between Aberdeen and Pakenhain were sent to Elliot, and thus are to be found in the documents of Elliot's consulate in Texas. These documents were all removed to London when Texas finally ceased to be an independent republic, 
Although the cessation of hostilities between Mexico and Texas was regarded by the foreign office in London as a step gained, the satisfaction was short-lived owing to the American proffer of annexation which so promptly followed it. Still, while the Texan refusal to act until the United States Senate should formally sanction the offer was reassuring, diplomatic affairs moved rapidly in this new country, and Aberdeen felt that he must be on the alert. The public clamor aroused by his conference with the antislavery committee in the summer of 1843 had been unpleasant and caused him anxiety, and when he learned through Pakenham and others of the consequent irritation in the United States, he endeavored to dispel the storm of criticism he had provoked. On December 26, I843, he addressed a communication to Pakenham with instructions to present the same to Upshur. This was the first of those letters which were afterwards published and came to be known in history as the Calhoun-Pakenham correspondence. Pakenham, however, did not obey this instruction immediately, and the letter was not presented to the American government until the following February. Meantime, Aberdeen received a copy of President Tyler's annual message to Congress outlining a policy of annexation; and, highly indignant at some of the phrases it contained which hinted at British interference in the affairs of Texas, he again wrote to Pakenham. In this letter of January 9 Aberdeen frankly expressed his indignation at the tone of the president's message, and assigned to Pakenham the ungrateful task of enlightening Upshur upon the point. He concluded: "I have now to desire that in executing that Instruction, 
you will take the opportunity of observing to the Secretary of State, that the language of the President, when speaking of the measures which the U. States may hereafter have occasion to adopt, ill accords with this condemnation of the supposed designs of other powers. You will state to Mr. Upshur, that H. M's. Govt. would have been glad if they could have discovered in the Message greater evidence of that disinterested policy, the presumed absence of which in other quarters, the President has thought necessary to call to the Notice of his Countrymen."3

This instruction served only to relieve the British secretary then and to throw light on the British attitude later, for it was never presented by Pakenham, and is therefore not included in the published correspondence. It shows that Aberdeen was thoroughly angry, and that he did not hesitate to resent unjust accusations from the American president. In his letters, and in his general denial of charges insinuated in Tyler's message, Aberdeen laid great stress upon the slavery question always. He denied that Great Britain had any intention of attempting to secure abolition in Texas by improper or indirect methods, and he conveyed the impression that British sins, from the American point of view, were all embodied in her abolition hopes and sentiments. With each protestation he managed to explain the energies of Great Britain upon the basis of her antislavery theories and to solidify American opposition upon the same score. Thus it was possible to distract attention in the United States from any definite British effort to prevent United States annexation of Texas. Plans looking to this very desirable

${ }^{8}$ F. O. Texas, 20. Copy sent to Elliot. 


\section{58 CALHOUN-PAKENHAM CORRESPONDENCE.}

end were, however, under consideration at the foreign office, even while abolition in general was the theme of 'Aberdeen's instructions. These plans required that France and England unite to prevent that annexation. Doubtless the president's message to Congress inspired this new move. It may be that Aberdeen was stirred into action by it, but it is more likely that the message convinced him that annexation was really imminent, and that boldness was required in order to prevent it. On January 12 he instructed Cowley in Paris 4 to bring Tyler's message to the attention of the French government :-

It is true that no direct mention is there made either of Great Britain or of France; and it is also true that, in noticing the possibility of interference on the part of other great and powerful Nations, in the affairs of the neighbouring Republics, the President appears to have alluded solely to Great Britain. At the same time, it is sufficiently evident that the future annexation of Texas to the United States is contemplated by the President and considering that France as well as Great Britain has recognized the Independence of Texas, and entered into a Treaty with that Republic, and that the Interests of the two countries in that part of America are, in all respects, the same, H. M's Govt presume that the Government of France would not any more than that of Great Britain, look with indifference upon any measure, by which Texas should cease to exist as a separate and independent State.

I have to desire that Y. E. will ascertain from M. Guizot whether the views of $H$ M's Govt on this subject are shared by the Government of France; and, if so, you will propose that the Representatives of the two Govts. at Washington and in Texas, should be instructed to hold the same lan-

'F. O. Texas, 20. Copies of all important despatches exchanged by Aberdeen and Cowley on the Texan question were sent to the British agents in Mexico and Texas. References to such despatches are therefore made to the volume where first found. 
guage, deprecating all interference on the part of the United States in the affairs of Texas, or the adoption of any measure leading to the destruction of the separate existence of that State; at the same time, warning the Texian Govt not to furnish the United States with any just cause of complaint, and encouraging them to look to the preservation of their independence, as the best security for their ultimate prosperity, both political and commercial.

This instruction can have no other meaning than that Aberdeen was ready to go to the length of a direct prohibition of annexation in case he found France acquiescent. It is true that in itself the instruction does not state this in so many words, but there could have been no purpose in the measure as outlined if Great Britain and France were not prepared to defend their plan to any extent necessary. On the other hand, it is more than probable that Aberdeen believed that the combined efforts of two formidable European states would be effective in preventing annexation without resorting to more forcible methods. No doubt, too, he underestimated both the strength of annexation sentiments in America and the daring of the United States government. He probably never dreamed that the United States would venture to annex Texas in the face of vigorous objection from England and France.

Cowley's reply to Aberdeen was written on January 15. ${ }^{5}$ He had found the king of France and his minister, Guizot, in perfect sympathy with Aberdeen's ideas. He said:-

It was apparent, the King observed, from the President's Message, that it was in serious contemplation to add Texas to the Union: That, in his opinion, this ought to be opposed, for it would be for the advantage of all Maritime States, for France and Great Britain in particular, that the Inde-

${ }^{5}$ F. O. Texas, 20. 
pendence of Texas should be maintained, and that a barrier should thus be opposed to the encroachments of the United States, whose object was not only to take possession of Texas, but at some future period to make that Province a stepping stone to Mexico. His Majesty added that he had desired M. Guizot to instruct the French Ambassador in London to communicate with Your Lordship on this subject, which he considered to be one of no slight importance.

M. Guizot, upon my communicating to him Your Lordship's Despatch and its Enclosures, fully concurred in Your Lordship's opinion as to the course to be pursued with the Govt. of the United States, and said that he would forthwith send Instructions to $M$. de Ste. Auliare to confer with Your Lordship upon this subject: He would also, he said, direct the French Minister at Washington to act in strict concert with Mr. Pakenham in everything relating to this Matter. M. Guizot was of opinion that it was of importance that the designs of the Govt. of the United States with respect to Texas, should be prevented.

The concluding words of this report by Cowley indicate a perfect understanding by France of Aberdeen's purposes. ${ }^{6}$ Thus Aberdeen believed that he was building a really formidable barrier to the American annexation of Texas. His plan, naturally, presupposed an immediate Mexican recognition of Texan independence, thus depriving Texas of an excuse for consenting to annexation. The working machinery of the plan was not yet set in motion, and meantime

- This is the only despatch referring to the supposed protest to be found. The inference is that the matter ended where it began, or rather that the document went no farther than to the British and French ministers at Washington. There is no evidence that any such protest was ever made, or that instructions for its presentation were actually given. It will be seen later that both Pakenham and the French minister believed that the positions assumed by their respective governments were too aggressive, and after conference together, they decided to allow themselves a margin of discretion in carrying out the plans laid down for them. 
singring

from Texas and from America came the welcome news that no such haste was required as had at first seemed necessary. Elliot wrote to Aberdeen on April 7 that he was back again in Galveston for a few days, and that he found Houston very much embarrassed by the pressure being put upon him from Washington, but still firm in his desire for independence. Houston had, in fact, told Elliot that Henderson, the new Texan agent sent to Washington, was instructed to demand such terms of the United States as it could not possibly grant. These impossible terms were incorporated in Houston's demand that the United States place a force upon the border of Texas to defend that State against Mexico. Elliot wrote that if the projected treaty should fail, Houston was anxious that Great Britain and France should " find means of preventing all further risk of complication in that direction." "Y Yet, with all his confidence in Houston's intentions and sincerity, Elliot could not let matters rest without an attempt to get to the bottom of the public rumors of annexation. On his own authority, and contrary to Pakenham's advice, he asked for an official explanation, but failed to receive any satisfactory reply. Doubtless he felt himself justified by the general instructions Aberdeen had sent him in the previous year.

In spite of all assurance by Elliot to the contrary, events at Washington, D. C., were moving with greater rapidity than had been expected by any of the British agents. After the death of Upshur, as a result of an explosion on board the "Princeton," Calhoun had

'F. O. Texas, 9. Elliot's' correspondence shows that Houston did tell him the exact truth with regard to all that was taking place in Texas between himself and Murphy. 
been called to the department of state. He arrived in Washington in the latter part of March, and was soon in control of the situation, taking up with enthusiasm the project for the annexation of Texas, and pushing it with more ability and shrewdness than had been shown by Upshur. The impossible terms which, by Houston's instructions, were a condition to a consideration by Texas of American advances had been refused by Tyler. When Calhoun succeeded Upshur, that refusal was withdrawn, Texas was conceded border protection pending the negotiation, and a treaty was speedily drawn with representatives of that State. The treaty was signed on April I2, but it was not sent to the Senate until April 22, and with it was presented, among other correspondence, a portion of the so-called Calhoun-Pakenham letters. ${ }^{8}$ These included Aberdeen's instruction of December 26, 1843, and a reply thereto by Calhoun. Aberdeen's letter had been written, as has been stated, to help clear up the misunderstanding regarding the abolition convention and to deny any "occult design" to bring about abolition in Texas with the purpose of influencing the institution of slavery in the United States. Aberdeen had admitted the general interest that Great Britain had in the subject of abolition "throughout the world," but added that British motives were open, and that Great Britain would never act secretly in this connection. "She has no thought or intention of seeking to act directly or indirectly in a political sense on the United States through Texas." Unfortunately, some general and quite unnecessary reflections referring to the institution of

${ }^{8}$ See before, p. 156 . 
slavery in the United States were added to this broad outline of English policy. There is no proof that these were intended in a captious spirit, but they were quite superfluous, gave cause for irritation, and were therefore unwise. ${ }^{9}$

Calhoun's reply, presented with Aberdeen's letter, is well known and need not be stated at length. For the sake of recalling his exact expressions it may not be amiss, however, to quote a few sentences. Referring to Aberdeen's acknowledged general interest in abolition " throughout the world," Calhoun admitted Eng- . land's right to concern herself with abolition among her own colonies, but "when she goes beyond, and avows it to be her settled policy, and the object of her constant exertions, to abolish it throughout the world, she makes it the duty of all other countries, whose safety or prosperity may be endangered by her policy, to adopt such measures as they may deem necessary for their protection." Calhoun then took up the defense of slavery as an institution, and surely no champion of a cause was ever more sincere, more ardent, or more eloquent. Should Great Britain succeed in

- The Calhoun-Pakenham letters may be found in Sessional Papers, 1847, Commons, Vol. 64. This collection contains one letter from Pakenham to Aberdeen, dated April 28, r844, which was not published in the United States. In it Pakenham wrote: "Your Lordship will perceive with surprise and displeasure, . . . that the explanations furnished by $\mathrm{Her}$ Majesty's Government ... have been received in a sense quite contrary to their obvious and literal meaning." As additions to these letters there should be noted also the unpublished letter previously cited from Aberdeen to Pakenham, of January 9, 1844, and another to which attention will be directed later, bearing date of June $3, \mathbf{1 8 4 4}$. These have never been published. 
her desires, he wrote that "she would involve in the greatest calamity, the whole country, and especially the race which it is the avowed object of her exertions to benefit." As a result of Aberdeen's pronouncement of British plans, the United States "can no longer refuse, consistently with their own peace and security," to meet the request for Texan annexation. Thus Aberdeen's letter, intended specifically to divert American attention from the projected plan for Texan annexation, was made the excuse for immediate action in that very matter. It was, of course, the last thing Aberdeen expected. That his efforts to center attention upon Great Britain's philanthropic interests should result in riveting the attention of the American government upon Texas seemed the irony of fate. The result at the time would have been more disastrous to British interests if Calhoun's published letter had had the effect he hoped and expected. Unfortunately for him, however, he had overestimated his case, and his countrymen were not ready to subscribe to his broad statements of the need for slavery and for Texas. America was not yet ready to assume the issue here put forward by Calhoun. This public opinion was immediately reflected in the Senate, and it came to be noised abroad that the Senate would not ratify the treaty. Thus Calhoun, no less than Aberdeen, faced a totally unexpected situation when this correspondence was made public. Sympathizing with the antiCalhoun element in the United States, Aberdeen was confirmed in the belief that there was still time to interfere in American plans in Texas, and he decided to proceed with his overture to France. Indeed, Aberdeen might well feel that in aiding to block Calhoun's 
plan, he was in reality acting in harmony with the wishes of the greater part of the American public. This last, of course, was not the case. The American public was rapidly coming to desire Texas, but of this Aberdeen was not as yet convinced. Taken all in all, the very fire and force of Calhoun's letter defeated its own ends. He went too far for his countrymen, and he angered Aberdeen. If he believed that his threats would serve to intimidate the British minister, or to deter him from further effort to defeat American plans, he was wrong in his reckoning. Aberdeen, irritated by such distortion of his statements and such wilful misinterpretation of his motives, resolved the more firmly to carry out his own plans and thereby foil Calhoun in his designs. From Texas, Elliot commented upon the general dismay among conservative men in America at the boldness of Calhoun's attack upon Aberdeen, adding that he was sure the Senate would refuse to ratify the treaty, and that thus Mexico would have one more chance to act wisely. "It may be depended upon," he said "that if Mexico can be induced to acknowledge the Independence of Texas, the Government and people would reject any renewed overtures for annexation to the North American Union. Their recent consent has been less the result of a desire to form part of that Union, than of a belief that the agitation of such a project would dispose the Government of Mexico to acknowledge their Independence."10

The same impression was prevalent among American diplomats elsewhere. With a general belief that the treaty would be lost in the Senate, immediate public interest subsided. On May I8 Everett wrote to Cal-

${ }^{10}$ F. O. Texas, 9, Elliot to Aberdeen, May Io, I844. 
houn that news of the proposed treaty had aroused no great interest in England, and that there was much less excitement about the matter than he would have expected. Among the newspapers the Times alone was as vicious as usual. ${ }^{11}$ The subject had indeed attracted some attention in Parliament, for on May I7 Brougham had asked for information, and had desired to know what Great Britain was doing relative to the reported American treaty of annexation. Aberdeen refused to give any information. On May 20, in the Commons, Hume asked for papers, and indicated his belief that the British government was attempting an unjust interference in the internal affairs of other countries. Peel refused to give the papers. ${ }^{12}$ Thus neither the public nor the press in England knew whether or not Aberdeen was really planning any action in regard to Texas.

In Mexico the news that a treaty of annexation was being negotiated at Washington caused the greatest excitement and consternation. British residents and official representatives there were hardly less affected by such news than the Mexicans themselves, yet England's power and influence in Mexico were at a low ebb at this critical juncture. The affair of Doyle and the flag had so far undermined British authority that Doyle's successor, Bankhead, found his path a difficult one. His tact and energies for the first few months were exclusively devoted to restoring the old friendly and confidential relations between the two countries. Meantime, all questions that might cause embarrassment, or that could in any way mar the harmony that

${ }^{11}$ H. R. Ex. Doc. No. 27I, p. I00, 28th Cong., Ist sess.

${ }^{12}$ Hansard, 3rd Ser., LXXIV, I227, 1330. 
Bankhead proposed to establish, were postponed or ignored. Certainly until British prestige was reestablished there was to be no pressure upon the Mexican government in any direction. This policy was carried so far that Bocanegra, the foreign minister, was told that England would never use "force" to compel Mexico to recognize Texas. ${ }^{13}$ Doubtless Bankhead's bearing in Mexico was quite in line with the instructions with which he had left England, but the necessity to attempt pressure came too soon. When conditions in regard to Texas obliged Aberdeen to say that Mexico must act in accordance with British plans, the change in attitude was most marked, and the feeling in Mexico was all the more irritated because of that change. The conciliatory attitude assumed by Bankhead upon his first arrival, therefore, later operated against Mexican acquiescence in British plans.

By the end of May, Aberdeen had resolved to collect all his forces and to put into immediate operation his plan to prevent American annexation of Texas. On May 29 he had a long interview with Murphy, the Mexican minister in London, as a result of which Murphy drew up a note containing his understanding of the purport of that interview, and submitted it to the British foreign office. This was transmitted to Aberdeen on May 3I. It was written in French, and, after having been amended by interlineary corrections in English, was returned to Murphy, while a copy was kept by Aberdeen. The note with the changes and additions indicated by italics is here given in full as best summarizing the plan that Aberdeen had now determined to put into effect:-

${ }^{13}$ F. O. Mexico, 173, Bankhead to Aberdeen, March 3I, I844. 
Après avoir conféré sur d'autres affaires, Lord Aberdeen fit allusion au traité d'annexation du Texas aux Etats Unis. Je fis observer à Son $\mathrm{Ex}^{\mathrm{ee}}$ : que je me trouvais sans instructions à ce sujet, mais qu'il n'était point douteux que le Gouv ${ }^{t}$. Mexicain ne tolérerait pas l'outrage qui avait été fait à ses droits. Lord Aberdeen exprima le désir de voir le Mexique se prêter à la reconnaissance de l'indépendance du Texas. "Si le Mexique," dit-il, "veut céder sur ce point, l'Angleterre s'opposera (et j'ai lieu de croire que la France se joindra à elle dans cette résolution) à l'annexation du Texas, et de plus he would endeavour that la France et l'Angleterre garantiront ensembles non seulement l'indépendance du Texas, mais aussi les limites du Mexique. Si au contraire le Mexique persistait dans son refus de reconnaitre l'indépendance du Texas, les intentions de l'Angleterre d'empêcher l'annexation de ce pays aux Etats Unis pourraient ne pas être mises à exécution." Sur mon observation qu'il n'était nullement probable que le Gouv ${ }^{t}$ : Américain consentit désormais à abandonner la question de l'annexation, quand même le Sénat Américain repousserait le Traité quant à présent; Lord Aberdeen répliqua que provided that England and France were perfectly agreed, "peu importerait à l'Angleterre que le Gouvt. Américain consentît ou non à abandonner cette question, et que, s'il était nécessaire, elle irait jusq'aux dernières extrémités pour soutenir sa résolution contre l'annexation; mais qu'à cet effet il fallait que le Mexique fût prêt à reconnaître l'indépendance du Texas, car, dans l'état actuel des choses, le Mexique et l'Angleterre marchaient sur des voies différentes, l'un s'opposant à l'annexation pour garder possession du territoire, et l'autre pour en assurer l'indépendance." Lord Aberdeen ajouta que c'était pour l'Angleterre la seule voie qu'elle pourrait suivre aujourd'hui attendu que l'indépendance du Texas avait été reconnue par le Gouv ${ }^{t}$ : Britannique; que lui (Lord Aberdeen) n'aurait point reconnu [substitution: "perhaps should not have been disposed to acknowledge"], cette indépendance, mais que cette reconnaissance ayant eu lieu, ce n'était qu'en faveur de l'indépendance que l'Angleterre pourrait s'opposer à l'annexation. "Je ne suis pas prêt," continua Son Excellence, "à faire encore aucune proposition formelle au Mexique à ce sujet; j'attends la résolution du Sénat Américain sur le traité dont il s'agit, et l'aspect que présenteront les affaires; mais je ferai cette proposition formelle aussitôt que je serai éclairé 
sur ces points and as soon as an understanding can be completed with the French Government. Il doit être bien entendu, cependant, que l'Angleterre ne fera pas de l'abolition de l'esclavage au Texas une condition de la reconnaissance de l'indépendance de ce pays par le Mexique."

Je rappelai à Lord Aberdeen que cette offre avait été faite au Mexique. "Cela est vrai," répliqua Son Excellence, "mais le Mexique, lorsqu'elle fut faite, ne la prit point en considération."

It would undoubtedly have been highly satisfactory to the British Govt. if the abolition of Slavery in Texas could have been effected in consequence of the recognition of its independence by Mexico; but as Great Britain had herself acknowledged that independence without any such stipulation, it was quite impossible to recommend that it should be made an indispensable condition by the Mexican Government. ${ }^{14}$

The substance, then, of this proposal was that Mexico should immediately recognize Texan independence, and that, upon such recognition, England and France would definitely offer opposition to American annexation and would endeavor to guarantee the independence of Texas and the territorial limits of Texas and Mexico. Aberdeen made plain that should Mexico refuse to recognize Texas, Great Britain could neither oppose annexation nor guarantee the territorial limits. He also here asserted that little importance was to be attached to the intentions of the United States if Great Britain and France were agreed in their action. All ideas of asking Mexico to urge Texas to abolish slavery were now abandoned.

On June 2 Aberdeen had an interview with Ashbel Smith, going over this same ground with the purpose of securing from Smith a definite pledge that Texas

${ }^{14}$ F. O. Mexico, I80, Dom., Mr. Murphy. Murphy's note states that the interview was held upon the 28th, but Aberdeen's later references to it always specify the 29 th as the correct date. 
would not permit herself to be annexed in case Mexico should make peace. ${ }^{15}$ Smith told Aberdeen that "in my individual opinion, if a solid permanent peace were established with Mexico and a treaty of commerce with Spain so as to enable us to trade with Cuba, Texas would prefer to remain independant; that if the British and French Govts. would say authoritatively to Mexico, you must forthwith make a solid and permanent peace with Texas, that Mexico would do so, and that the annexation of Texas to the American Union would not take place."

This interview is evidence of an underlying hesitation felt by Aberdeen in the future action of the Texan government. His plan was, to his mind, feasible if it were not wrecked by the desire of Texas to be annexed to the United States. While he totally underestimated this element in the situation, it was yet sufficiently present in his mind to make him hesitate, or at least to make him feel very anxious to secure pledges that Texas would take no such step.

Before the interview with Smith, however, Aberdeen had already transmitted a direct proposal to France, based upon the plan drawn up in the inter-

${ }^{15}$ F. O. Texas, II, Dom., Ashbel Smith. The substance of this interview is found in a letter from Smith to Rate, written from Paris, September 23, I844. In that letter Rate was instructed to secure an interview with some one at the foreign office and present the substance of the statements made by Smith to Aberdeen in their interview of June 2. Smith summarized for Rate's benefit his own statements in that interview. The matter does not appear anywhere else, but there is no question that Smith's summarization contains the substance of what actually took place. He did in fact give to Aberdeen a definite statement of what he believed would be the policy of Texas. 
view with Murphy. On May 3I he had instructed Cowley to present the matter to the French government. This appears in an instruction sent to Bankhead on June 3 , in which Aberdeen stated at length the contents of his directions to Cowley. In substance these amounted to the adoption of a plan by which Great Britain and France would impose peace on Mexico, and would guarantee to Texas that her independence should be respected by other powers. Here also it will be noted that Aberdeen was troubled by the fear that Texas might willingly be annexed to the United States:-

You will therein see that we have submitted a proposition to the French Govt for a joint operation on the part of Great Britain and France in order to induce Mexico to acknowledge the independence of Texas, on a guarantee being jointly given by us that that independence shall be respected by other Nations, and that the Mexico-Texian boundary shall be secured from further encroachment.

Should France assent to this proposal, we propose to send out forthwith a fit person to Texas, in the unavoidable absence of Captain Elliot, who will be instructed to ascertain as accurately as he may be able the state of publick opinion and feeling with respect to the projected annexation of Texas to the United States, under the security of the joint guarantee above described. If, as we are led to believe the publick feeling, under such a security for the future peace of the Country, should be in favour of independence, we shall then take measures forthwith for operating directly and officially upon the Mexican Govt. which we shall hope to find amenable to our views, as eminently advantageous to that Republick. Should they, however, refuse their assent, or still demur to the acknowledgment of Texas, it will be for England and France to take such further measures for attaining the desired object as they may deem expedient. ${ }^{10}$

The substance, then, of the plan is quite clear. It differed only slightly from the earlier suggestions to

${ }^{10}$ F. O. Mexico, 172 . 
this end, but in addition to the provisions of previously outlined plans it involved a guarantee of Texan independence against other powers. This necessarily meant that if such a plan were perfected and Mexico conceded recognition to the Texan Republic, Great Britain and France must be prepared to use force if necessary to prevent the absorption of Texas by the United States. No other conclusion is possible, and by making such a proposal to France, Aberdeen practically announced his willingness to go to the point of war with the United States. Presumably he had no expectation whatever that the United States would carry the matter so far. His information led him to believe that the government of Texas desired independence, and although he had every reason to count upon opposition from the people he nevertheless hoped that they would be guided by their rulers. With the knowledge that the Texan government stood unanimously for independence, and that Great Britain and France would support it and guarantee the territory, the American government, he felt sure, would take no further step toward annexation. 'Aberdeen, then, while outlining the plan that involved a remote possibility of war, never seriously thought that war would result.

Upon the same day that this communication was sent to Bankhead with instructions that it be urged upon the Mexican government, a long letter was addressed to Pakenham, which took up the reflections of Calhoun upon English policy and in conciliatory language attempted to allay the irritation of the American public:- 
I think it right, however, to state that Her Majesty's Government have no intention to press at this time the abolition of domestic slavery on the Government of Texas. The Treaty by which Great Britain recognized the Independence of Texas having been concluded in I840, without any stipulation for that object, Her Majesty's Government consider that they would not be justified in urging that point authoritatively upon the Government of Texas. Neither do they consider themselves authorized under the circumstances above stated, to press the Government of Mexico to make the abolition of domestic slavery a sine qua non with Texas for the recognition of its Independence by Mexico. But Her Majesty's Government, although abstaining from such interference, do not the less deplore the existence of domestic slavery in a new Country which has scarcely struggled into existence; and they reserve to themselves the right which they possess, whenever they may think it expedient, to offer friendly counsel to Texas to take measures for the ultimate liberation of the Country from the stain and calamity of domestic slavery.

In making this declaration, however, I again unequivocally state that counsel alone, and not dictation, would be employed for this object.

It is but just and candid to add that the United States stand, with respect to domestic slavery, in a very different position from Texas. The evil,-for, notwithstanding $\mathrm{Mr}$. Calhoun's arguments, I must still consider it an enormous evil,-was not of their seeking. Slavery was introduced into their Country, against the will of its Inhabitants, by the Britis's Government in the earlier times of British dominion. Therefore, however deeply Her Majesty's Government may deplore the existence of such an evil in that great and free Country, they cannot but admit the difficulty of its extirpation; and they feel it also to be so much the more incumbent on them to refrain carefully from any steps which could affect the interests of the United States in this particular. The Governments of the slaveholding States of the Union may, therefore, repose with entire confidence on the good faith of Great Britain in this respect. ${ }^{17}$

That these two instructions, the one friendly and pacific, the other unyielding and determined, and both

${ }^{17}$ F. O. America, 403, June 3, I844. 
concerned with the same country, were posted upon the same day is surely interesting. While the letters form a notable contrast in tone and differ distinctly when it comes to an expression of ultimate aims, they do not, after careful analysis, necessarily conflict. That Aberdeen expected, however, that his letter to Pakenham would be accepted at its face value, and thus be misleading as to his real purpose, seems certain. His emphatic denials of any British designs regarding abolition in Texas, even through Mexico, were intended to distract attention from the project of preventing annexation already under way. His instructions to Pakenham in no way conveyed a promise that Great Britain would not oppose the annexation of Texas. Yet by carefully laying all the emphasis upon the matter of abolition, and by reiterating the British policy of non-interference with slavery, the impression was certainly created that opposition to annexation itself did not exist. Indeed, this instruction, with its clever omissions and its cordial spirit, written so long after the publication of the CalhounPakenham correspondence, seems very like an attempt to lull the suspicions of the American government.

Aberdeen was, in fact, continuing preparations for a British-French combination against the annexation of Texas. On June 24 he had a further interview with Ashbel Smith, proposing a "diplomatick Act" by which England and France, acting with Texas and Mexico in any case, and with the United States if the last named could be secured, were to settle the boundaries of Texas and guarantee its independence. Such an agreement would have involved a pledge upon the part of Texas not to permit herself to be annexed 
to the United States. ${ }^{18}$ Smith, though not in favor of this particular plan, assured Aberdeen that Texas was extremely anxious to maintain its independence. Thus, by the middle of June, 1844, in the same month that the American Senate was rejecting the treaty of annexation, 'Aberdeen was rapidly maturing the project of a united opposition to that annexation.

${ }^{18} \mathrm{~F}$. O. Texas, II, and see Worley, 42. 


\section{CHAPTER VIII.}

Aberdeen's Withdrawal from Joint Action with FRANCE.

The first half of the year 1844 saw the rapid development of Aberdeen's carefully constructed plan for joint action with France. Before it could be put to the test, adverse conditions forbade resorting to it, and in the latter half of the year it was hastily though definitely abandoned. While British agents in London and France were planning overtures in persuasion, or strategy, or whatever measures short of force might be needed to bring Mexico to accept the program laid out for her, Mexico herself was in the dark. The Mexican government had no information, and Bankhead had only such as reached him from Pakenham by way of Washington, or through public rumor. So when the news of the American proposal to annex Texas reached Mexico, it surprised Bankhead as well as the government. He was quite without instructions, and was therefore in great uncertainty as to his attitude in the matter. Though he had consistently pursued the ultra-conciliatory policy in all his dealings, when asked if England would aid Mexico to prevent annexation he would not commit his country to any definite assistance. He replied that England had always been a great friend of Mexico, but he declined to be drawn into any explicit promise. ${ }^{1}$ A month later

${ }^{1}$ F. O. Mexico, 174, Bankhead to Aberdeen, May 30, I844. 
Bankhead was assured by Santa Anna that rapid preparations were being made to reconquer Texas as the most effective means of preventing American annexation. Santa Anna asked what position Great Britain would take if this reconquest of Texas should lead to war with the United States, but again Bankhead refused to commit his government. ${ }^{2}$ In this instance Bankhead failed to carry out Aberdeen's policy, since the mere refusal to answer Santa Anna's question gave encouragement to Mexico. Bankhead really needed no specific instructions to meet this emergency, as England had definitely refused under any circumstances to aid Mexico to reconquer Texas. ${ }^{3}$ Thus the spirit in Mexico at the time when, to suit English purposes, it should have been most acquiescent was emphatically belligerent, and Bankhead was obliged to report that Mexico, instead of acknowledging Texan independence, was preparing to renew war upon that province. This would have meant inevitable war with the United States and her forcible annexation of Texas.

On June 8 the Senate of the United States had rejected the treaty with Texas. This did not mean the final disposal of the matter, for it was publicly rumored that President Tyler was determined to carry the measure through, and already by June II he had outlined in a message the plan of securing annexation by means of a joint resolution of both houses of Congress. Meantime, Pakenham was watching the progress of affairs with the keenest interest. He had held long conferences with his French colleague, Pageot, upon Great Britain's projected measures, and his con-

${ }^{2}$ F. O. Mexico, 174, Bankhead to Aberdeen, June 29, I844.

${ }^{8}$ See before, p. 102, Aberdeen to Pakenham, July 15, 1842. 
fidence in their success was waning. On June 27 he despatched a letter containing a very open and frank analysis of the entire situation, warning Aberdeen of probable disaster to British policy if the United States should really determine to annex Texas. He urged that the moment was badly chosen for the disclosure of a plan for joint action with France. The political campaign in America was on, and an announcement of British plans would be a most effective help to the cause of the annexationists. British policy should bend itself in every way to aid in the election of Clay and to defeat Polk. In all this he had the entire concurrence of the French minister, and both diplomats wrote to their governments in practically the same terms:-

It is scarcely necessary for us to remark that, by the rejection of the late Treaty the question of the annexation of Texas must not be considered as disposed of. On the contrary it must be looked upon as the question which at this moment most engages the attention of the American People, and which will form one of the most prominent Subjects of agitation and excitement during the approaching election to the Presidency. In fact it may be said that both questions will be tried at one and the same time: that is to say, if the feeling in favour of annexation should predominate, Mr. Polk, who stands upon that interest, and who has moreover the support of the democratic party, except where antiannexation feelings may operate against him, will be elected.

If happily the party opposed to annexation should prevail, Mr. Clay, who has taken a stand in opposition to that measure, will be the man; in which case, although the project must not even then be thought of as abandoned or defeated, there would at least be a prospect of its being discussed with the calmness and dignity required by its importance, and by the interest which other powers are justly entitled to take in it.

According to this view of the question it seems to us, My Lord, that the Govts. of England and France have everything to gain by the success of Mr. Clay: and accordingly that whatever might in any way unfavourably affect his prospects ought by all means to be avoided. 
Now I believe, My Lord, that one thing which greatly contributed to the rejection of the late Treaty, was the absence of all interference, at least open interference, in opposition to it on the part of England and France. Any demonstration of resistance on the part of those Govts would, I think, have had the very opposite effect to that intended, and would probably have led to the ratification of the Treaty instead of its rejection.

Following this same view of the question, it would appear that, pending the Election to the Presidency, the line of noninterference on the Texian question would be that most conducive to our interests: for which reason, we humbly submit, My Lord, that it is desirable that the most important arrangement contemplated by Your Lordship's late Despatch should not be known in this Country until after the Election shall have taken place.

Other considerations suggest themselves to us, My Lord, with reference to this important Subject, which although they will probably not have escaped Your Lordship's attention, I beg leave most respectfully to submit.

For instance, we are of opinion that in any Treaty or agreement which may be concluded with a view to the attainment of the object proposed, provision ought to be made from the beginning to allow the U. States to become a party to the engagement; and that the engagement ought, as far as possible, to have the appearance of a self-restricting engagement, rather than of an engagement involving opposition to the supposed designs of another Power. By this means some part of the odium which in this Country will most certainly, under the most favourable circumstances, attach to the Measure, may be got rid of.

Another consideration which we think ought not to be lost sight of, is, that any arrangement for a pacification between Mexico and Texas which should not make provision for the absolute Independence of the latter Country, would at this moment be worse than useless, inasmuch as it would only facilitate the accomplishment of those designs which England and France are most anxious to frustrate: and, finally, My Lord, it is our opinion that if the arrangement contemplated by Your Lordship should be effected, that is to say, if England and France should unite in determining to secure the Independence of Texas, without the consent and concurrence of this Country previously obtained, that deter- 
mination would probably not be met, in the first instance, by measures of open and declared hostility, but that Texas would be immediately annexed and occupied, leaving it to the Guaranteeing Powers to carry out the objects of the agreement as best they might.

On the other hand it is my firm belief that if either England or France were to undertake alone to accomplish what it is proposed that those Powers should undertake united, the announcement of such an intention would be met here by measures of the most extreme resistance. And, in whatever way the project may be announced here, I need scarcely add that it will form a crisis of the utmost delicacy in our relations with this Country.

Practically all of Pakenham's despatch is here presented for the reason that it furnished fundamental causes for a change in Aberdeen's policy. ${ }^{4}$

The effect of Pakenham's communication was immediate. His portrayal of the strength and depth of American feeling was a revelation to Aberdeen, and was extremely disconcerting. In his plan for joint action with France he had made but meagre allowance for United States opposition, and he had believed that

'F. O. Texas, 20. Copy transmitted to Elliot. At the same time several letters were received from Kennedy, consul at Galveston, stating in very emphatic language that the United States would not stop at war in its policy of annexation. Kennedy had no authority to write upon matters of British policy. Indeed, he had been directed to concern himself solely with commerce. He was, however, bitterly incensed at Elliot, and during Elliot's absence from Texas could not keep out of the game. He escaped direct disobedience, therefore, by sending private letters, together with official reports, to Aberdeen. $\mathrm{He}$ thus tried to secure a hearing, even though he had been instructed to the contrary. Aberdeen was annoyed by this evasion of an order, and Kennedy was later reproved for his letters. Nevertheless, the fact that he emphasized American readiness for war was just so much additional support of Pakenham's contention. F. O. Texas, Io. 
if accepted by Mexico and Texas it would effectually and peacefully prevent American annexation. He had so far committed himself with France as to propose a guarantee of the Texan State, and in view of French compliance and cordiality when joint action was first proposed, he had no reason to think that France would not act heartily with England. But even the cooperation of France would not insure a successful termination of the negotiation under such circumstances as Pakenham stated, and Aberdeen acted immediately. His plan was doomed to fail, and he saw it, although historians generally have not credited him with that foreknowledge. It has been a commonly accepted statement that Aberdeen's proposal to France failed because France herself withdrew and left England to undertake alone a hopeless task. Instead of this, Aberdeen paved the way for French withdrawal, stating a strong case to give France her opportunity. On July I8 he wrote to Cowley, enclosing Pakenham's despatch, and showing how greatly it had affected British policy:-

Mr. Pakenham's Despatches furnish much ground for serious reflection. It appears from them that both he and his French Colleague are decidedly of opinion that any ostensible interference at this moment, on the part of Foreign Govts, and especially the English Govt, in the Texian annexation Question, so far from advancing the object which we have in view, namely the prevention of the incorporation of Texas with the United States, would directly tend to defeat that object by throwing additional weight into the scale of Mr. Tyler or Mr. Polk, the Annexation Candidates for the Presidency, and proportionally diminishing Mr. Clay's chances of Election to the Presidential Chair.

H. M. Govt feel that this is at the present moment a very important consideration; and they are consequently disposed to defer, at all events until a more fitting season, the execu- 
I 82 ABERDEEN DECLINES JOINT ACTION WITH FRANCE.

tion of their projected measure of combined interposition with Mexico and Texas on the basis of the joint guarantee of the Independence of Texas and the frontiers of Mexico by Great Britain and France. ${ }^{5}$

This placed the emphasis upon the service which would be rendered to Clay in his campaign for the presidency by refraining from action. While the letter suggested postponement, it did not necessarily imply that the plan should be abandoned. This, however, is unquestionably what Aberdeen had in mind. Pakenham's despatch, with its reference to "extreme resistance," could mean only one thing, and by transmitting it Aberdeen gave to France a reason for her rejection of the plan. Having originally conceived the project and suggested it to France, it was impossible for England to withdraw without loss of dignity, hence Aberdeen's message to Cowley and the enclosing of Pakenham's letter. Should France decline to carry out her share in the original program, as would undoubtedly happen after the receipt of the instruction to Cowley, it could easily be said that the desertion of France had caused the failure. On July 22 Cowley reported that Guizot was quite willing to postpone a decision upon the matter. ${ }^{\text {e }}$ Both Great Britain and France were thus ready in July to postpone and, as will be seen later, definitely to set aside the project matured in May and June. This was before the instructions of Calhoun in August to King, the American minister to France, which were directed toward preventing a British-French combination in regard to

${ }^{5}$ F. O. Texas, 20. Copy transmitted to Elliot.

'F. O. Texas, 20. 
Texas. ${ }^{7} \quad$ In a labored analysis of the Texan situation Calhoun went over the whole ground of American interests in the West and Southwest, dwelt upon the customary friendship of France and the United States, and emphasized, on both commercial and political grounds, the idea that the interests of Great Britain and France were quite dissimilar in the new world. $\mathrm{He}$ repeated former arguments intended to prove the benefits of slavery to the subject race, and went so far as to assert that the mainspring of Great Britain's interest in abolition was a recognition of the bad economic results of her own emancipation in the West Indies and a jealousy of the superior conditions existing in the United States. These arguments were intended to prevent France from acting with Great Britain, and it has usually been supposed that they were a distinct influence in that direction. But if Pakenham's despatch of June 27 caused the change in British and French policy, then Calhoun's repeated efforts counted for nothing in determining French action. On the contrary, Guizot's line of action was virtually mapped out and France was committed to withdrawal before Calhoun's instructions to King were received.

While messages between Washington and London could be transmitted within a reasonable time, such was not the case where Texas or Mexico and England were concerned. Consequently the foreign office and its agents in the United States were in reasonably close touch when a bare three weeks would be required for

'There are two of these instructions, one dated August I, I844 (see Moore's Digest, I, 453), and another dated August I2 (see Calhoun's Works, V, 379). 
the delivery of despatches, while the long interval (sometimes two months or more) consumed in the journeyings of messages between Mexico and London gave opportunity for great changes in the interim. It thus happened that by the time the Murphy memorandum of May 29 reached Mexico, late in August, the plan therein outlined, insuring peace and harmony through the allied action of England and France, had already practically been discarded. Necessarily there was entire ignorance in Mexico of this shift in policy, and the memorandum was the cause of great excitement. When Bankhead received his copy of this important document, he immediately presented himself before the Mexican government for the purpose of discussing it. A series of conferences followed. ${ }^{8}$ Upon Santa Anna and the government the memorandum produced an effect the very reverse of that intended. It strengthened the war spirit, and drew from Santa Anna the statement that he would use all his energy to raise troops for the reconquest of Texas. Bankhead was skeptical of the President's sincerity, and expressed the belief that if money were raised for war, the greater part of it might find its way into Santa Anna's pockets. But Bankhead was distinctly annoyed by this Mexican bluster. Indeed, there were many difficulties to beset him if he hoped to further the ambition of Aberdeen at this time. Whatever his government required of him was to be read from the memorandum only. There were no definite instructions; pro-British sentiment, though carefully nursed, could not yet be depended upon, and annexation reports from the United States had called forth only hos-

'F. O. Mexico, 175, Bankhead to Aberdeen, August 29, 1844. 
tile expressions. The situation was not promising, and when he discovered that Santa Anna proposed to submit the Murphy memorandum to a secret session of Congress, he was much alarmed. Protest was made just in time to prevent this. The president had told one of the deputies, "I shall send this communication to the Congress,--shew them that England will stand by us,-and they must now give the money." And he had also added, "The English Government say we must either conquer Texas or grant its independence, -what will Congress say to that?" ${ }^{\circ}$ This was certainly a very remarkable perversion of the intent of the memorandum. Santa Anna's declared intention of using it before Congress and his absurd distortion of Aberdeen's meaning both show what unique stumbling-blocks the Mexican government found to obstruct Bankhead's path. At first all of Bankhead's energy was required to prevent public knowledge of the British proposals, and his first reports after the receipt of the memorandum showed that he was wholly ignorant of what action the Mexican government. would ultimately take, though expectant that a more reasonable view would soon prevail.

Long before any news could reach England from Mexico, Aberdeen had received the Pakenham despatch, and had acted upon it by communicating its contents to France. When, therefore, in September there reached him a despatch from Bankhead, written on June 29, stating that Santa Anna proposed to attack Texas in order to prevent American annexation, ${ }^{10}$ it found Aberdeen in no uncertain mind. Bankhead's

${ }^{\circ} \mathrm{F}$. O. Mexico, 175 .

${ }^{10} \mathrm{~F}$. O. Mexico, 174 . 
despatch had been written before it was possible for the Murphy memorandum to reach Mexico. Aberdeen of course knew this. He might reasonably have expected that document to check Santa Anna's warlike plans; nevertheless he at once replied to Bankhead, expressing his great astonishment at Mexican folly, and stating explicitly that if Mexico pursued such a policy, Great Britain would not help her. $\mathrm{He}$ wrote:-11

You will make known these sentiments to the Govt of Mexico, and, at the same time that you again urge that Government to suffer itself to be guided by the counsels of a Nation which, in offering its advice, seeks and can seek but the substantial good of Mexico, you will clearly point out to $M$. Bocanegra that if the President, contrary to our hopes and belief, were to take the rash step of invading Texas with a view to its forcible reconquest, and if, by so doing, he should find himself involved in difficulties with other Countries, he must not look for the support of Great Britain in aiding him to extricate himself from those difficulties.

Mexico received direct warning, and at the same time England disclaimed all responsibility in case Mexico should ask aid. Some three weeks later, October 23, I844, after hearing from Bankhead of the reception of the Murphy memorandum, Aberdeen wrote again and still more emphatically. ${ }^{12} \mathrm{He}$ said that Santa Anna's plan to make war on Texas was wholly opposed to the idea of English-French action, and the very existence of any such project defeated the purpose of the English-French-Mexican concert in advance; hence this international combination now ceased to exist. Here is definite proof of English

${ }^{11}$ F. O. Texas, 20, Aberdeen to Bankhead, September 30, 1844. Copy sent to Elliot. Original to Bankhead is missing.

${ }^{12}$ F. O. Mexico, 172 . 
withdrawal from the project of joint action before the English government had any direct refusal from France to go on with that action. Aberdeen's instruction of October 23 is based wholly upon Bankhead's first report of the reception given to the Murphy memorandum. In that first report, Bankhead, although frankly describing the difficulties presented by Santa 'A'nna's opposition, had expressed the belief that by a little manipulation he could bring the Mexican government to consent to the plan. Aberdeen, however, was not now willing to take any risks. It was a part of his line of defense against parliamentary criticism to inform Mexico at once that the plan of joint action was at an end. Having done so, even though France should not formally withdraw her support, he could assert that the failure of the plan was wholly due to Mexican folly.

The fact was that at the very time that Aberdeen was thus placing upon Mexico the responsibility for the failure of his project, Bankhead had secured from the Mexican government practical acquiescence in that plan. ${ }^{13}$ The English minister, in spite of all obstacles and of the inconsistencies of the Mexican government, was not daunted, and had continued to urge the general arrangement outlined by Aberdeen and Murphy. Bankhead then drew up with the Mexican foreign minister a scheme looking toward the operation of a joint guarantee of boundaries by England and France, after Mexican recognition of Texan independence. He did not sign any such document, nor did he pledge a British guarantee, ${ }^{13} \mathrm{~F}$. O. Mexico, 176, Bankhead to Aberdeen, October 30, I844. 
but he gave his advice as to the answer which Mexico should transmit to Great Britain. $\mathrm{He}$ was also in such close touch with the Mexican government that all of the voluminous correspondence then passing between the United States and Mexico on the question of Texas was submitted to him and received his censorship. Thus acting as the intimate adviser of Mexico, he transmitted on November 29 what appeared to him an acceptance in substance of Aberdeen's plan. $\mathrm{He}$ thought that the changes introduced were immaterial, or could easily be altered later. ${ }^{14}$ The document read as follows:-

Points on the settlement of which the Mexican Government might agree to grant the Independence of Texas, in compliance with the wish indicated by Her Majesty's Government.

Ist. Mexico will yield the Territory which is now occupied by the so called Republick of Texas, that is from the Rio Colorado to the Sabine and would at the same time mark out the Boundaries of the Interior Part of the Country.

2nd. Mexico by way of compensation demands an indemnity for the Territory so yielded-The guarantee of England and France united, that under no pretext whatever shall the Texans ever pass the Boundaries marked out. The same nations shall also guarantee to Mexico the Californias, New Mexico and the other points of the Northern frontier bordering on the United States, according to a Treaty to be drawn up for that purpose. - If the United States carry into effect the annexation of Texas, to the North American Union, England and France will assist Mexico in the contest which may be thereby brought on always under the supposition that Mexico shall have carried into effect the Recognition mentioned in Article I.

$3^{\text {rd. }}$ Until an answer shall have been received from England, which is requested to be sent with the least possible delay, Mexico will suspend all hostilities against Texas.

4th. The English Cabinet can either give her Minister here

${ }^{14}$ F. O. Mexico, 177. 
[power], or send a Commissioner charged with full powers, to treat upon the above Points and conclude the Negotiation.

While these terms differed materially in form from the terms that Aberdeen would have elaborated, Bankhead did not think the altered outline wholly unsuited to the situation, and he believed that in certain particulars it would be easy to amend it. Thus he wrote that the "compensation" required by Mexico could be provided by a return to the earlier scheme of Hamilton in which Texas was to assume a portion of the Mexican debt; that the restricted boundary line assigned to Texas was inserted merely to give Mexico something to offer in return for "compensation," and that Mexico could easily be induced to withdraw other articles if the guarantee of her northern boundary and of aid in case the United States annexed Texas were retained. These last two items were the essential ones in the Murphy memorandum, and if Bankhead was correct in stating that Mexico would not in the end insist on other points, he had good cause to feel that his diplomacy had been successful and that he was following closely Aberdeen's plan. Even the Mexican revolution in December of 1844, which drove Santa Anna from the presidency and placed Cuevas in control of foreign affairs, did not unsettle Bankhead's belief in Mexico's ultimate consent. Aberdeen had written on October 23 that the concert was at an end, but of this Bankhead was ignorant, and until the end of the year he persevered in his efforts to hold Mexico to the British point of view. He was unaware as late as December 3I, I844, that any change in British policy had taken place and that all of the negotiations which he had been conducting with the Mexican gov- 
I9O ABERDEEN DECLINES JOINT ACTION WITH FRANCE.

ernment were futile. They serve to show, however, that Bankhead, at least, did not believe that a change in British policy was necessitated by the action of the Mexican government. ${ }^{15}$

Bankhead's optimistic reports, however, would have wrought no change in Aberdeen's determination to avoid any serious trouble with the United States. In reply to his transmission of Pakenham's despatch of warning, France, on July 22, had definitely consented to defer action, but had left in uncertainty her exact position. Nominally, both England and France awaited the result of the presidential election in the United States. In reality, neither power desired to go on with the proposed joint action, and certainly Aberdeen but waited such an answer from Guizot as would free his hands. On December 2 Cowley was at last able to report a definite decision by Guizot. The French foreign minister, in the course of an interview relating to American affairs, had informed Cowley that France would join with Great Britain to prevent a Mexican invasion of Texas, but that further than that she would not go. This, then, was the end of the plan for a joint guarantee of Texan independence, and the news was welcome in London. Aberdeen was unquestionably relieved when he received Cowley's report of the interview :-

Generally speaking (M. Guizot continued) England having large possessions in America, has a greater interest than France in the question of Texian Independence.

I said that, this question being one of interest to both Govts, since both had recognized the Independence of Texas, he would no doubt act in concert with us in any negotiation I844.

${ }^{15}$ F. O. Mexico, I77, Bankhead to Aberdeen, December 3I, 
with the Mexican Govt. for the purpose of obtaining from them the acknowledgement of that Independence.- "Undoubtedly," he answered, "we will both use our best efforts for that purpose, and will even refuse to recognize the annexation of Texas to the United States; but, as a Question of Peace or War, I am not prepared to say that its junction with the American States is of sufficient importance to us to justify our having recourse to arms in order to prevent it."16

The languagé here used was such as to make it perfectly possible for Aberdeen to emphasize French hesitation and to defend his own policy before the British Parliament, if necessary. The closing weeks of December saw him released from all outside obligations, and he was left free to pursue whatever offered England the greatest advantage. The demand for a new policy was imperative from the moment that Pakenham's despatch revealed the depth and intensity of American feeling regarding annexation. Fortunately for the ministry, this change of purpose had not to be immediately formulated. French concurrence in deferred action permitted time for observation and consideration, and when in December the Guizot decision left England free to announce a new policy, Aberdeen was ready. The cardinal principle of the program was more negative than positive, and committed the government to avoid war with the United States at all costs. At the same time England was to use her influence to secure Texan independence and to persuade Mexico to recognize that independence. In the first instruction to Bankhead after the receipt of Cowley's despatch by the foreign office Mexico was severely arraigned for her sins of governmental conduct, and little consideration or sym${ }^{16} \mathrm{~F}$. O. Texas, 20, transmitted to Elliot. 
pathy was shown for the plight in which she found herself. Indeed, Aberdeen went so far as to charge her with the entire responsibility for her unhappy position. Nevertheless, he still urged a prompt recognition of the Texan Republic. He said:-

You will also again clearly explain to the Mexican Govt that they must not count upon the assistance of Gt. Britain, whose friendly advice they have constantly neglected in enabling them to resist any attack which may at any time, now or hereafter, be made upon Mexico by the U. States, since they will have wilfully exposed themselves to such attacks by omitting to make a friend and dependent of Texas while it was yet time.

You will further state that the conduct pursued by the Mexican Govt must effectually paralyse the exertions by which Gt. Britain and France were prepared to uphold the Independence of Texas against the encroachments of the $U$. States, even at the risk of a collision with that Power, with which it is the desire and Interest of both to remain on terms of friendship. ${ }^{17}$

In this last paragraph Aberdeen possibly made clever use of verb tenses to state matters with exactness and yet convey a wrong impression. To write that the acts of Mexico "must effectually paralyse" BritishFrench exertions implied that a change of Mexican policy might still insure the support of the two powers, while the use of the past tense in the words "were prepared" did not indicate with complete frankness that all plans of further exertions in the matter were definitely set aside. The instruction as written conveyed no promise to Mexico, yet might be so interpreted as still to furnish a reason for Mexican recognition of Texas.

\footnotetext{
${ }^{17} \mathrm{~F}$. O. Texas, 20, Aberdeen to Bankhead, December 3I, I844.
} 
On the same date on which Aberdeen wrote to Bankhead, December 3I, I844, he wrote also to Elliot in Texas, to Pakenham at Washington, and to British agents in California and on the Pacific Coast. ${ }^{18}$ The instruction to Elliot was most comprehensive, and with it Aberdeen sent copies of all the correspondence with Cowley, Pakenham's despatch of June 27, and the instructions to Bankhead. He thus gave Elliot a complete knowledge of the situation. He wrote:-

These Papers will put you in possession of the line of conduct which Her Majesty's Government have pursued and intend to pursue both with regard to Mexico and to the United States, with reference to Texas. That line of conduct may be summed up in a few words. It is to urge Mexico by every available argument, and in every practicable manner, to recognize without delay the Independence of Texas, as the only rational course to be taken for securing the real Interest of Mexico, to which Country the Annexation of Texas to the United States would be ruinous; while, on the other hand, we have carefully abstained from any ostensible Act which could inflame the wild and dangerous spirit which, partly for national, but more for party purposes, has been roused and sustained by demagogues in the United States, in favour of the Annexation of Texas, and which wanted but the evidence of active interference on the part of Great Britain to be kindled at once into a flame.

This policy we propose still to pursue, because, under present circumstances, and until we can see our way more clearly with reference to the intentions of Mexico, as well as to those of the United States, under the altered circumstances which the Election of a new President may exhibit, we think a passive course, or rather a course of observation, the most

${ }^{18}$ For the importance of the California correspondence, see Chapter XI. Briefly, these California instructions were to the effect that British agents must do nothing to stir up revolution in California against Mexico, but at the same time, if such revolution actually occurred, British interests must be protected, and the annexation of California to the United States prevented, if possible. 
prudent, and the least likely to involve us in difficulties with Mexico or with the United States. ${ }^{19}$

In addition, Aberdeen stated that the attitude of his government toward the independence of Texas was in no way changed, but that it was essential that the agents of Great Britain use the greatest caution in dealing with this affair, to prevent the appearance of any open opposition between British and American interests. Aberdeen believed that Great Britain could still depend upon the sincerity of the Texan government, and that that government might still be able to control the Texan public. Apparently, then, in the face of many discouragements Aberdeen still hoped for a successful issue in the case of Texas. To sustain that hope were the personnel of the Texan government, in which he still had confidence, and the potentiality of Great Britain to coerce Mexico when coercion seemed necessary. If the Mexican government could be induced to make peace with Texas on the basis of independence, and if the Texan government could convert popular demand for annexation into popular acceptance of that independence, then British pressure on the United States would happily be unnecessary. Peace and harmony with the United States came first, and all other advantages were to be sacrificed to that. There was no fear of war with the United States, nor doubt of its results, but rather a distinct national antipathy to the suggestion of such a war. Aberdeen could have made no more unpopular move than to ask his country's support of it. Englishmen in the forties were not only disinclined to

${ }^{19}$ F. O. Texas, 9. 
fight their trans-Atlantic brothers, but they would have dismissed the government that asked it of them.

While at the close of 1844 Aberdeen's determination to abandon opposition to American annexation of Texas had become the keystone of a fixed policy, the Texan government had not been apprised of the fact. The treaty of annexation had been rejected by the United States Senate on June 8, and Houston soon after recalled his agents from Washington. Apparently he did not look upon the matter of British intervention as finally settled, for Anson Jones states that Houston issued orders in September to secure at once the ratification of the agreement proposed by Aberdeen to Ashbel Smith on June $24 .^{20}$ This was the so-called "Diplomatick A'ct" by. which England and France, together with Texas, Mexico, and the United States (if the last named could be secured), were to settle the boundaries of Texas and guarantee its independence. There is conflicting testimony as to Jones's action in this connection, for Reeves's narrative differs materially here from the documents in London. According to his account, Jones later declared that he refused to carry out Houston's orders, basing his refusal upon the fact that he was the president-elect of the Texan Republic and that Houston's term of service would soon end. ${ }^{21}$ This is not in harmony with the evidence at the Record Office, for Elliot reported in December that Jones was most urgent in his effort to secure prompt action by Great Britain in the matter of the British-French com-

${ }^{20}$ Reeves, 175.

${ }^{21}$ Ibid. 
bination with regard to Texas. ${ }^{22}$ Jones's efforts to arouse the British government to activity were wholly unfruitful. ${ }^{23}$ Elliot, so recently in the United States and under the influence of Pakenham, felt very strongly the force of United States sentiment and of Pakenham's objections to such a project. As yet without any instructions other than those transmitted by Pakenham, he refused to be drawn into any hasty action. It was not, therefore, until the following year, when he received definite instructions to that effect, that he made a last effort to prevent American annexation.

${ }^{22}$ F. O. Texas, 9, Elliot to Aberdeen, December io, 2I and 28, I844.

${ }^{23}$ Anson Jones was born in Mássachusetts in 1798 , and died in Texas, in 1858, by his own hand, having become insane in his later years. He was a physician, practising in Philadelphia, New Orleans, South America, and going to Texas in 1833 , when he became a leader in the revolutionary movement. From 1837 to 1839 he was Texan minister to the United States; from $184 \mathrm{I}$ to 1844 he was Houston's secretary of state; and in 1845 he was chosen president. Jones was popularly supposed to desire an independent state and to be against annexation, losing political influence because of this suspicion. He wrote a defense, published after his death, to disprove the allegation, and Reeves accepts this, at least to the extent of believing that Jones desired annexation, while keeping open the road to independence. 


\section{CHAPTER IX.}

1845. Elliot's Mission to Mexico.

The defeat of Clay and the choice of Polk in the November elections of 1844 practically settled the matter of American annexation so far as the government of the United States was concerned. Donelson was sent to Texas with instructions so broad that he could practically pledge his government to a determined effort to conclude the matter. In the minds of Tyler and his intimate advisers the only uncertainty was in regard to the date for a new and, it was hoped, final proposal to Texas. For some time it was undecided whether this should occur during the Tyler administration or after the inauguration of the new president. It soon appeared, however, that Tyler intended to arrange the matter during his own incumbency, in order that the acquisition of Texas might date from his presidency and be his final claim to fame. There was not sufficient time before the close of his term of office for the conclusion of all formalities, but the president desired that at least it should be his fortune to make such an offer to Texas as would be certain of acceptance.

While the pronounced intention to forward the annexation program was known to those in the confidence of the administration and to many American politicians, it was neither discussed nor suspected outside this close circle, and British officials, both in the 
United States and at home, were wholly in the dark. Pakenham had clearly stated probabilities when, in his letter to Aberdeen, he had predicted that Polk's election and a Democratic victory would mean greatly increased support for annexation, but immediate action in that direction he had not foreseen. Prepared for a reopening of the question, and perhaps for subsequent discussion and organized opposition, he hardly expected so prompt a termination.

To Aberdeen the defeat of Clay and the unfavorable conditions attending upon it brought genuine discouragement, and his instructions of December $3 \mathrm{I}$ betray his hopelessness at that time. There was sudden reaction from this frame of mind, however, when in January he received from Bankhead Santa Anna's acceptance of the Murphy memorandum. From Elliot also came the reassuring news that Jones, the new president of the Texan Republic, was still anxious to prevent annexation. Distinctly encouraged, therefore, Aberdeen late in January wrote to Elliot in reference to the Mexican acceptance of the British overture, urging upon Texas the advantages of the decision to which the Mexican government had now consented. No actual guarantee, he admitted, could be offered by Great Britain, and he barely hinted at possible modifications of Santa 'Anna's plan. He avoided any discussion of these, however, although frankly ridiculing Santa Anna's ideas as to limiting Texan territory. Aberdeen further stated that Calhoun's assertion that a rift existed between Great Britain and France and that the two states were not pursuing a similar policy, was false. In proof of this, he enclosed instructions sent by Guizot to Savigny 
in Texas, drawn in practically the same terms as those he now sent to Elliot. Aberdeen hoped that the government of Texas would meet that of Mexico half-way and would "avail themselves of the good offices of Great Britain and France with a view to the modification of the terms now offered by General Santa Anna and to rendering them such as Texas can honourably and advantageously accept." He made a vague reference to the extent to which England and France would commit themselves to assure peaceful relations between Mexico and Texas. This might mean much or little. Of course the implication was that Texas should have adequate support from her European friends, but, phrased as this was, it was unsatisfying rather than encouraging. "You may also add that, although Her Majesty's Government would not be disposed to undertake their share of the responsibility, which, for the security of the possessions of Mexico, General Santa Anna would impose on England and France, yet, that, under certain circumstances, those Powers would not refuse to take part in an arrangement by which Texas and Mexico should be bound each to respect the Territory of the other."1

${ }^{1}$ F. O. Texas, 2I, Aberdeen to Elliot, January 23, 1845. The enclosed.copy of Guizot's note to Savigny closely paralleled Aberdeen's own instructions:-

(I) "Nous pensons toujours que l'Indépendance du Texas importe à la balance politique de l'Amérique, et que la France et L'Angleterre, en particulier, ont interét à ne pas voir disparaître un état dont elles viennent de reconnaitre l'existence."

(2) As to guarantee, Savigny is instructed: "Que dans certains cas, et sous certaines conditions, elles ne se refuseraient pas à intervenir dans un arrangement, par lequel le Mexique et le Texas s'obligeraient à respecter leur Territoire et leur Indépendance réciproques." 
The comprehensiveness of Elliot's instructions, the detail, and the very apparent effort to induce Texan acceptance indicate a reversal in the positions of Texas and Mexico. Two years earlier the acquiescence of Texas was counted on, when Mexican stubbornness refused to yield. With the contrary situation-Mexico's readiness to accept a docile partit was upon Texas that British effort and eloquence were to be expended.

With Bankhead it was unnecessary to go into great detail. The minister at Mexico had been so far effective that Aberdeen practically left to his discretion such further activities as the situation might demand. Then, too, there was the uncertainty as to the continuance of the Mexican government, it being more than likely that Santa Anna had been superseded in power. ${ }^{2}$ Whatever the situation in Mexico, Aberdeen's previous instruction to Bankhead was surely unlikely to secure a ready acquiescence. Indeed, it is surprising that Aberdeen could have hoped for a satisfactory answer from Mexico after sending his letter of December 3I, which was so filled with accusation and criticism of the government. Nevertheless, English dictation to Mexico had been frequent; it was almost a tradition, and apparently Aberdeen expected it to be accepted in this instance. In the end he was fortunate in the actual fate of his instruction of December 3I, 1844, for it was never presented. It arrived in Mexico not long after the revolution which displaced Santa Anna, and Bankhead, in view of this political change, had not communicated it. The

${ }^{2}$ F. O. Mexico, 183, Aberdeen to Bankhead, February 3, 1845 . 
Mexican government was, therefore, never cognizant of the severity of Aberdeen's language or of his proposed policy of leaving Mexico to shift for herself. In the new government Bankhead found the minister of foreign affairs, Cuevas, ready to present to Congress the project of Texan recognition if he could at the same time be assured of British and French approval and "support." 3

Unquestionably there was still ground to hope for Texan independence, in spite of the movement to annex in the United States. Neither Houston nor Jones publicly favored annexation, and Houston went so far as to advise the immediate conclusion of an agreement with Mexico. Jones in his inaugural address failed to express himself as favoring annexation. ${ }^{4}$ The gen-

${ }^{3}$ F. O. Mexico, 184, Bankhead to Aberdeen, January 29, 1845. Cuevas had also proposed to bring up the abolition question again in the treaty with Texas, but on this point Bankhead evaded any reply, and in doing so, reported that he was following the verbal instructions of Aberdeen given to him before setting out for Mexico.

"The substance of Jones's "defense" in his autobiography is that while favoring annexation, he adopted a policy tending to keep open the chance of securing support from England and France and of establishing a strong independent state in case the annexation project again came to nothing. Jones, in justifying himself, attacks Houston, asserting that he (Jones) refused, while still secretary of state, to carry out Houston's orders looking toward English-French intervention. As already stated, this contention is not borne out by the documents in the Record Office. On the other hand, the autobiography states that Jones was always perfectly frank with Elliot in explaining the exact situation to him and in expressing the conviction that Texas was so set upon annexation that it was very improbable any other result could be secured. Elliot's reports to Aberdeen show this to be the truth, Jones always emphasizing the fact that he was but the agent of the people and must execute their will. 
eral inference was that the strong men of the Texan government were opposed to annexation, and Elliot so reported to Aberdeen, believing that the independent element was really gaining control of the situation. ${ }^{5}$ Yet by this time Tyler's plans were very generally known. He had conceived a project to take up the subject in Congress by joint resolutions and thus to carry the matter to a successful issue without submitting a treaty to the Senate. This was still the subject of bitter discussion in Congress. Friends of annexation were positive that the Tyler program would go through, while on the other side an equally strong belief existed that Congress would never consent to these proposals. With the arrival of the news that the annexation resolutions had passed the House of Representatives, Mexico at last became thoroughly aroused and keenly apprehensive. Bankhead, writing to Aberdeen on March I, I845, reported that throughout the country there was the greatest excitement, and that there had never before been such apparent readiness to concede Texan independence. Cuevas announced that he was prepared to give his consent, and that he was confident that the Mexican Congress would also support the cause if he could but assure them of the backing of Great Britain. Much as Bankhead hoped to see such action taken, he could not give the desired assurance. He was extremely cautious in his reply to Cuevas, emphasizing the fact that "any assistance from England must be a moral one, for that whatever disposition may have at one time

${ }^{5}$ F. O. Texas, I3, Elliot to Aberdeen, February 8, 1845. 
existed to go beyond that line, had now been withdrawn." 6

The progress of Tyler's annexation program had been fairly rapid. In his message of December 3, 1844, the president had advocated the passage of a joint resolution by Congress authorizing the executive to carry out the compact with Texas. A resolution to this effect passed the House of Representatives on January 25, 1845 , but met objection in the Senate, and was finally amended in such a way as to permit the president either to renew a negotiation looking toward a formal treaty or to proceed on the more direct plan outlined in the resolution of the House. Thus amended, the matter passed the Senate on February 28 , and received the president's signature on March I. Unquestionably it was the expectation of the majority in Congress that it would fall to the incoming president, Polk, to deal with the affair, and that he would prefer a negotiation conducted on ordinary diplomatic lines. But Tyler was greedy of fame, and on March 3, a few hours before the close of his administration, he approved instructions to Donelson which offered annexation to the Texan Republic. This was soon known to Pakenham, but in spite of it, writing as late as March 29, he reported to Aberdeen that the latest news from Texas was of a revulsion there against annexation, and that a refusal of Tyler's overture was not impossible. He believed, at any rate, that there would be no immediate acceptance by the Texan government. From various sources, then, Aberdeen received such information as encouraged

${ }^{6} \mathrm{~F}$. O. Texas, 2I, Bankhead to Aberdeen. Copy sent to Elliot. 
him to believe that annexation was not a foregone conclusion. He hoped yet that some action might be taken to persuade Texas to remain independent, and immediately upon receiving Pakenham's despatch he wrote to Cowley, stating that reports from Washington, from Texas, and from Mexico indicated that there was still an opportunity to bring about an agreement between Mexico and Texas. At the same time, Cowley was instructed to inform Guizot that this was the last chance, and that both powers should act with promptness and energy. In addition Aberdeen made it perfectly clear that Great Britain would undertake nothing that could involve her in war with the United States, writing, "Her Majesty's Government ... do not conceive that they would be justified in exposing Great Britain to the serious risks of a war in seeking to establish that [Texan] independence." $7 \mathrm{He}$ proposed that France unite with England in a joint instruction to their agents in Mexico and Texas urging the one state to grant and the other to accept independence. France and Great Britain were to offer their joint mediation for this purpose, but with no responsibility or guarantee whatever. He wrote:-

They [Great Britain] would not wish to require any formal declaration on the part of either of those States beyond an assurance that they accepted such joint mediation and good offices, and engagement on the part of Texas to use every effort to maintain its own independence. Moreover H. M's Govt. would not propose to enter into any guarantee whatever with respect to either of the States, whether to secure to Mexico the inviolability of Her frontier against Texas, or to secure to Texas its frontier against the United States or Mexico. In fact H. M's Govt. would not be disposed to place themselves in any respect in a position which might

${ }^{7}$ F. O. Texas, 21, Aberdeen to Cowley, April I5, 1845. 
give to Mexico or to Texas the power of hereafter calling upon Great Britain, as a matter of right, for her protection and succour against encroachment on the part of any other Powers, nor even of leading the Mexican Govt. to hope that such succour might be afforded. ... They would merely wish to exert all the weight of their moral influence, added to that of France, in order to secure the present pacification and future stability both of Mexico and Texas.

Guizot at once agreed to the proposal. ${ }^{8}$ His affirmative reply gave Aberdeen the chance to send to Bankhead one more message looking toward Texan independence. He immediately set about preparing this final and comprehensive instruction, which urged haste upon Mexico and regarded the measure as the only possible means of preserving the nationality of Texas. In this letter Aberdeen reviewed British efforts in Mexico from the close of Palmerston's ministry, and dwelt upon the various advances and suggestions of Great Britain and Mexico's subsequent postponements or refusals. He presented once more the arguments for a Mexican concession of independence and the benefits to be derived by both Mexico and Texas. There was also the specific statement that no British guarantee need be counted upon, and Bankhead was especially warned to refrain from any discussion of the acts or policy of the United States. ${ }^{9}$ While this instruction was based upon a slender thread of hope, it was immediately despatched to Bankhead. Two days later Aberdeen transmitted to Elliot a copy of a "declaration" agreed on by France and England which Elliot was to present to the government of Texas if affairs were still favorable to its reception.

${ }^{8} \mathrm{~F}$. O. Texas, 21, Cowley to Aberdeen, April 28, 1845.

${ }^{\circ}$ F. O. Texas, 2I, Aberdeen to Bankhead, May I, 1845 . 
This declaration, if presented, was to be signed by Elliot, Savigny, and the president of Texas. It stated that "their said Majesties engage to use their best exertions with a view to the restoration of Peace at the earliest possible period, and to the recognition of the Independence of the Republick of Texas by the Mexican Republick. And the president of the Republick of Texas has, on his part, authorized the Undersigned to declare on the other hand that the Govt. of Texas will use every effort to maintain the independence of the Republick under its own separate and national Jurisdiction."10

At the same time Aberdeen transmitted to Elliot copies of all the correspondence bearing upon the determination of England and France with regard to Texas. This instruction was based upon the assumption that there was a revulsion of feeling in Texas against annexation. That this assumption was far from being conviction is clear from Aberdeen's warning Elliot of the delicacy of his position if public sentiment should be unfavorable. In that case Elliot was to act with the greatest care, always remembering that friendly relations with the United States were to be maintained at any cost. This was Aberdeen's final instruction to Elliot concerning Texan independence. Even so, it was freighted with misgivings as to a successful result of the effort. Perhaps it was already too late, yet English endeavor to preserve the new republic was not to be stayed while any slight chance remained. In the event of ultimate failure it should not be said that Aberdeen had left any stone un${ }^{10}$ F. O. Texas, 2I, May 3, I845. 
turned or that he had been deterred from any legitimate attempt by the probability of disappointment.

In the end, however, the declaration of England and France was never presented to the Texan government, as it arrived too late to be of service. Elliot's activities in Texas had been undirected by the foreign office during the winter of $1844-1845$, and were dictated solely by reports from the United States and knowledge of political conditions there. Such information concerning the question of annexation as reached him led him to assume a generally passive attitude for which, as yet, he had no definite instruction, Aberdeen's message of December 3I not reaching Texas until February. With the arrival of this instruction, advising just such a course of inactivity as had been pursued, Elliot had the distinct satisfaction of having intuitively grasped Aberdeen's policy. Early in March, however, Ashbel Smith withdrew from his European post to become secretary of state under Jones, and he immediately sought Elliot for conference, bringing forward again the cause of independence. In his interview with Elliot he affirmed the growing sentiment against annexation among his countrymen, and described conditions as he wished them presented to Aberdeen. Among Smith's suggestions was one that Texas voluntarily pledge herself never to annex to any other country, provided Mexico promptly recognized her independence and England consented to act as arbiter in any boundary dispute between Texas and Mexico. In regard to such projected measures it was quite impossible to get an expression from Elliot, although Smith made every effort. Elliot reported all these conferences to the foreign office, but limited himself to careful state- 
ments. As to the boundary question, he was strongly opposed to a British guaranty in any case. ${ }^{11}$ Evidently there was some contagion of hope in Smith's earnestness, for on March 22 Elliot wrote to Aberdeen that the supreme necessity for Texas was an immediate offer from Mexico of independence. He did not, however, permit his reviving hope to lead him into any active effort for the cause of independence, but still mindful of the instructions of December 3 , refrained from meddling in Texan politics. ${ }^{12}$

In April Elliot received news from Bankhead that Mexico was intensely interested in the return of Smith to Texas and in the possible result of his efforts there. ${ }^{13}$ Bankhead and the French minister had conferred with Cuevas, and Bankhead was convinced that if the Texan government was sincere, Mexico would readily do her part. Two days after Elliot wrote his letter of March 22 to Aberdeen he received the joint instructions of Great Britain and France, sent out in January of 1845 . The receipt of these at once changed the entire situation for both Elliot and Savigny, and they determined to act with energy and vigor. They knew of the previous activities of Donelson, Tyler's representative, in preparing for annexation, and had just learned of the vote in the American Senate authorizing a direct offer to Texas. Before this news reached Texas, Donelson had left the State and was on his way to New Orleans. Elliot and Savigny believed that Donelson would soon return commissioned to conclude annexation formalities with such speed as he could.

"F. O. Texas, I3, Elliot to Aberdeen, March 6, I845.

${ }^{12}$ F. O. Texas, 13 .

${ }^{13}$ F. O. Texas, 23, Bankhead to Elliot, April 8, 1845. 
Hence both men at once started for Washington on the Brazos, the capital of the Texan State, in order to prevent if possible any immediate acceptance of United States proposals. ${ }^{14}$

Arrived at the seat of government, Elliot and Savigny had a series of interviews with President Jones, Ashbel Smith, and various members of the cabinet. These men told Elliot very frankly that while they desired independence, their first duty was to execute the will of the country, which clamored for annexation. The best they could do now, they said, was to delay decision, thus giving opportunity for the ultimate acceptance of some other measure than annexation. The opinion was openly expressed, however, as reported by. Elliot, that the people of Texas were so determined upon annexation that all steps to avert that measure would be quite useless. But Elliot, invigorated by active measures, and possibly carried away by his own enthusiasm, found much encouragement in the Texan government's promise of delay, and thought that the delay itself might very well end in a defeat of American policy. Elliot reported at length to Aberdeen the steps taken and the arguments advanced by himself and his colleague sending also a copy of a document signed by Ashbel Smith, Savigny, and himself. The securing of the document was referred to as an achievement in which Elliot took much satisfaction.

${ }^{14}$ Washington on the Brazos was declared the seat of government by Houston in 1842 , at a time when it was feared that Santa Anna was about to attack the town of Austin. Jones was inaugurated at Washington in 1845 . The place was very small, with but few inhabitants, and the government was installed in a room over Hatfield's grocery store or saloon. After annexation Austin again became the capital. 
It had been readily accepted by President Jones, and with his consent had been signed by Smith, after a personal pledge on the part of Elliot and Savigny that it should be known only to the courts of London and Paris, to their ministers at Washington, D. C., and, necessarily, to the Mexican government. In order to carry out the plan outlined in this document, Elliot urged upon Jones that Ashbel Smith should be sent at once to Europe and Allen appointed secretary of state in his place. This was agreed to, and the nominations were made. Elliot himself offered. to take the document to Mexico secretly and at the same time to use his personal influence with the government there. ${ }^{15}$ This document consisted of two articles which made the following requirements:-

Ist The signature and seal of the Secretary of State or any other Minister of the Republic of Texas duly authorized by the Government thereof, to be procured to the preliminary conditions now submitted to the Representatives of the two Powers, and the Government of Texas pledges itself forthwith after the same shall be placed in the hands of the President to issue a Proclamation announcing the conclusion of the preliminaries of peace with the Republic of Mexico.

and Texas for a period of ninety days from the date of this Memorandum agrees not to accept any proposals, nor to enter into any negotiations to annex Herself to any other Country.

In addition to this, a brief proposal of peace stating the points necessary to such a treaty accompanied this document :-

Conditions preliminary to a treaty of peace between Mexico and Texas.

I. Mexico consents to acknowledge the Independence of Texas.

${ }^{16} \mathrm{~F}$. O. Texas, 13, Elliot to Aberdeen, April 2, 1845. 
II. Texas engages that she will stipulate in the Treaty not to annex herself or become subject to any Country whatever.

III. Limits and other conditions to be matters of arrangement in the final treaty.

IV. Texas will be willing to remit disputed points respecting territory and other matters to the arbitration of umpires.

Done at Washington on the Brasos on the 29 of March, 1845 .

Elliot then made arrangements for immediate departure for Mexico, and just before setting out received from Bankhead a most encouraging letter. Bankhead, with the sanction of Cuevas, assured him that Mexico was ready to welcome a proposal of peace from Texas. This assurance seemed to Elliot most auspicious. His journey and the business which occasioned it were to be kept profoundly secret. It was absolutely essential to the success of the undertaking -at least so Elliot believed-that no suspicion be aroused in the public mind as to what was on foot, and especially that the government of the United States remain ignorant of British interference in Texas. Thus Elliot, under pretext of a journey to Charleston, South Carolina, left Texas on H. M. S. "Electra." When out of sight of land he was transferred to another British ship, the "Eurydice," under the command of Captain George Elliot. The "Eurydice" was bound for Vera Cruz, from which point her captain, George Elliot, proceeded overland to the City of Mexico ostensibly to carry British despatches to Bankhead, and Charles Elliot, with his precious documents, accompanied the captain incognito. ${ }^{10}$ Thus the jour-

${ }^{16}$ F. O. Mexico, I92, Dom. Var., Captain George Elliot to Sir Charles Adam, April 4, 1845, explaining the plan. 
ney to Mexico was managed with extreme caution, and was carried through apparently without arousing curiosity or comment. Bankhead had been notified that Elliot was to come, and he was ready to unite his endeavors with those of Elliot and the French minister toward an acceptance of the Texan proposal. While at this time Bankhead was more than ready to second Elliot's enterprise, in the earlier stages of the negotiation he had been plainly lukewarm. Doubting Great Britain's intention to give adequate support to Mexico, he had felt the hopelessness of active measures and had confined his earlier energies to encouraging pacific relations between the irritated Mexican officials and the United States. Gradually, however, he had become more sanguine, and finally convinced himself, apparently without any ground for it, that Aberdeen would not push the peace negotiation unless he definitely proposed to strengthen moral suasion with force if it became necessary. ${ }^{17}$

The Mexican cabinet listened to the proposal and to the arguments of the French and British agents that it be accepted immediately and without alteration. 'After much difficulty their combined efforts were successful, and Cuevas finally promised his signature and acceptance. Bankhead was elated at this turn of affairs. He reported to Aberdeen that Elliot was then in Mexico, that his mission was already a success, and that the consent of Mexico had been promised and the formal answer would be ready "tomorrow." The unexpected British victory he attributed largely to his own energy and persistence in the matter. Like Elliot, he believed implicitly in the sincerity of Jones ${ }^{27}$ F. O. Mexico, I84, Bankhead to Aberdeen, March 3I, 1845 . 
and Ashbel Smith in this offer, and took it for granted that with the signature of Mexico, American annexation would be an impossibility. ${ }^{18}$ The "tomorrow" of Cuevas proved, however, to be the proverbial Spanish "mañana." Nearly three weeks elapsed before the Mexican government finally attached its signature to the document, and not then until such changes were made as were considered "essential to the maintenance of Mexican honor." Cuevas asserted that the delay in final action was caused by the opposition of a small faction in the cabinet. This obstreperous element contended that Great Britain's interest in Texas was purely selfish, and that her ultimate intention was to acquire the State as a colony. The final signature for which all waited was secured only after Cuevas had won over this difficult faction. Bankhead's earlier elation had wholly subsided in the intervening three weeks, and had been succeeded by bitter irritation, directed particularly at the unreasonable delay and at the stupidity of Mexican officials. The type of intellect manifested by the chairman of the committee in Congress, to whom the matter was first referred, was quite beyond his comprehension; this person wasted several days " in order to draw up a labored report which began by a dissertation on the conduct of the Duke of Alva in the Low Countries and thence down to the question of Texas." 19 When the document was once signed, however, Bankhead felt not only relief but that a great result had been obtained. Both he and Elliot were, however, gravely anxious because of the lapse of time occasioned by Mexican delay.

${ }^{18}$ F. O. Mexico, 185, Bankhead to Aberdeen, April 29, 1845.

${ }^{20}$ F. O. Mexico, 185, Bankhead to Aberdeen, May 20, 1845 . 
On May I9 the signature of Mexico was affixed to the document so long under discussion; on May 20 Bankhead prepared a letter to Elliot transmitting the Mexican acceptance of the agreement, and on May 23 Elliot set out upon his return journey to Texas. Again it was intended that the mission should be kept secret, and provision was made to conceal Elliot's identity, while the errand which required a messenger to go to Texas pretended to be the transmission of the Mexican acceptance. So Elliot carried the letter addressed to himself to be presented by himself to the Texan president. As the return journey progressed, there appears to have been less caution maintained as to secrecy, for by the time of Elliot's arrival in Texas rumors in regard to his mission were afloat. The knowledge that the undertaking had been crowned by success may have explained relaxed efforts in the direction of secrecy; at any rate, all attempts to guard the secret were abandoned soon after Elliot was again on Texas soil.

When the report of the Mexican mission appeared in the public press of the United States it aroused the greatest indignation, as might have been expected. Here was a capital opportunity to charge Great Britain with "secret" designs, it being known that Elliot had had a "secret" part in it. Of Texas there was no serious condemnation, the transaction being interpreted as an intrigue on the part of Texas to push the United States to prompt action. Intrigue was not creditable to Texas, to be sure, but inasmuch as it was based on loyalty to American interests and not on disaffection it could be condoned. Jones and his advisers were credited with inveigling Elliot and Savigny 
into their scheme and persuading Elliot to accept the mission to Mexico,-all to bring pressure upon the United States. To read into such a negotiation the steady adherence to future incorporation with the United States was thoroughly gratifying to that government and its people. To attribute loyalty to the Texans necessarily implied in this instance unjustifiable interference on the part of Great Britain, and unquestionably, from the point of view of the United States, this charge was well founded.

Unfortunately, as is commonly the case when negotiations of importance first obtain publicity, the judgment of the United States was founded on half knowledge, and in this instance that incomplete knowledge has held until the present. There are, however, many facts that clear Great Britain of the charges of duplicity which circulated so freely at the time and also seem to attest the sincerity of the Texan government. In the first place, Texas, at the moment that the Mexican mission was undertaken, was perfectly free to make any national arrangement she chose. The Tyler offer had not been presented, and no formal notification of its approach had been given her. Indeed, Donelson, having previously left Texas, did not learn of Tyler's offer until he had reached New Orleans. Returning with all speed, he met and passed Elliot and Savigny just ten miles outside the Texan capital, as they were starting to Galveston and Mexico.

As to the claim that Texas originated the manoeuver and used Elliot as a tool, the correspondence shows that Elliot's activities were directed solely by instructions from his chief. His quiescence in the early part of 1845 , his later reluctance to enter into any plan 
with Ashbel Smith, followed by his sudden and energetic efforts in behalf of independence when Aberdeen's January letter was received, show that not Texas but England inspired his action. With the receipt on March 24, I845, of the January instructions, both Elliot and Savigny took the initiative, did the urging, and secured the consent of the Texan government to the project. Elliot also took great pride in the part he had taken, and comforted himself with the thought that, whatever the outcome, he at least had played a creditable rôle. That he believed absolutely in the sincerity of the Texan government is unquestionable. As to the sincerity of Jones and Smith, that can neither be affirmed nor denied upon the basis of their belief in the plan. Even though wholly skeptical of results, they may have been perfectly sincere in encouraging and forwarding a project which might offer an advantage to their country. It was surely justifiable policy to permit Elliot to prepare an alternative plan which might be available in case anything should happen to break off the negotiations with the United States. The good faith of the Texan government is still further emphasized by the fact that Donelson knew nothing of British intervention until late in May, when the envoys were returning from Mexico. Previous to that date, he had heard rumors of British intrigue, but had pretty generally discredited them. Indeed, his errand in Texas accomplished, he started upon his return journey to Washington after having repeatedly assured the United States government that there was nothing in the reports of English interference. He had proceeded as far as Iberville, in Louisiana, when, on May 22, further disquieting news 
reached him, which so aroused his suspicion that he again returned to Texas. In Galveston he met Elliot on the latter's return from Mexico, and heard for the first time and from Elliot himself the exact terms of the proposals carried to the Mexican government. ${ }^{20}$

Elliot, en route from Mexico to the Texan capital, reached Galveston on May 3 $\mathrm{I}$, and was angered at the unanimity and strength of the cry for annexation. Rumor had already been occupied with his travels, and so much of his enterprise was guessed at that further efforts to maintain its secrecy were abandoned. Though fearing that he was already too late, he hastened to get in touch with President Jones and to complete his mission by delivering to the Texan government the documents he had brought from Mexico. Jones immediately declared peace with Mexico in accordance with the terms of these documents, and soon after summoned a convention in order to lay before that body both the proposals of Mexico and the offer of the United States. To Elliot the calling of this convention offered but slight encouragement. The recent revelation of public sentiment showed but too plainly that a decision in favor of annexation was a foregone conclusion. His own presence in the Texan capital aroused suspicion and doubtless strengthened the cause of the annexationists. He realized this, and determined to save the situation as far as it lay in his power by leaving the country. ${ }^{21}$ Before leaving his post, for which he was later reprimanded by Aberdeen, Elliot had received Aberdeen's instructions of May 3,

${ }^{20}$ H. R. Ex. Doc. No. 2, 29th Cong., Ist sess., Donelson to Buchanan, June 2, I845.

${ }^{21}$ F. O. Texas, I3, Elliot to Aberdeen, June I2, 1845. 
with the plan of a document to be signed by himself, Savigny, and the authorities in Texas. He did not disclose this document, feeling that many of Aberdeen's points had been anticipated in the recent negotiation with Mexico and that nothing could be gained by present action. His letters at the time, both to Aberdeen and to Bankhead in Mexico, indicate his uncertain frame of mind. In the main, he was despondent, and believed that a victory for British policy was impossible. Jones and others had assured him, however, that the strong men of the Texan government still looked toward independence, and Elliot did not quite give up hope that they might ultimately find means to defeat the public demands. Nevertheless, in the confidence that his presence could only embarrass the party opposed to annexation, and apprehending only defeat for it under any circumstances, he despatched his letters and left for New York. With his departure from Texas all intimate relations between himself and the Texan leaders ceased, as did also any active participation in Texan affairs. 


\section{CHAPTER X.}

1846. Texas Annexed. Conclusion.

There was genuine rejoicing in London when Elliot's communication of April 2, with its documentary enclosure was received. Aberdeen was distinctly elated over the success of Elliot and Savigny in outlining this document and getting Texan acquiescence, as well as over the proposed mission to Mexico which should make it effective. On May $3 \mathbf{I}$ he wrote to Bankhead in terms of enthusiastic appreciation, stating that Great Britain and France had "by the dexterity and activity of their Agents in Texas, undoubtedly gained an advantage in checking the successful progress of the Annexation Project." ${ }^{1}$ Knowing only of the projected mission, and sympathizing with its purpose, his letter to Bankhead was intended chiefly to express British official support of Elliot's enterprise. $\mathrm{He}$ wrote that if Mexico still stubbornly refused to accept British advice, Great Britain and France would wash their hands of the matter, and would " consider themselves entirely absolved from all further interference in the affairs of Mexico with reference to the United States."

The friendly relations of England and the United States at the moment had been seriously threatened by certain statements in the president's inaugural address. Polk's bold announcement that the United

${ }^{1}$ F. O. Mexico, 183 . 
States would concede none of the British contentions with regard to Oregon had inspired hostile sentiments in England, and for a short time war between England and the United States seemed quite possible. Coincidentally with the prevailing sense of tension in England and the consequent vexation at Polk's arrogance came the announcement of Elliot's proposed mission to Mexico. Under any circumstances Aberdeen would probably have sanctioned the plan, but his support of it in this instance may easily have been the more enthusiastic because England had been given a rebuff by the United States.

Elliot's further report of his errand, with an account of the wearisome Mexican delays, reached London shortly after the arrival of the welcome news that it was under way. Although the message was sent in advance of the literal completion of the mission, Aberdeen read failure in the weeks of postponement. $\mathrm{He}$ now wrote that he was without "any sanguine hope that the President of Texas will have been enabled to resist the popular clamour for annexation." Indeed, he felt the utter hopelessness of any means of defeating the plan of the United States, and resented the secrecy and mystery that clothed the expedition from start to finish. For this he reproved Elliot, though generously commending the fertility and invention that inspired the enterprise as well as the energy with which it was conducted. The secrecy, however, laid Great Britain open to the charge of intriguing in Texas, a manner of interference not in harmony with British policy and one which England strongly deplored. Indeed, it had been the pride of British diplomacy that its methods had been always frank 
and open. ${ }^{2}$ Besides his comment on this specific undertaking, Aberdeen included in his letter a general exposition of British policy in America. The constant object of that diplomacy was to maintain peace on the North American continent. He believed that British interests were secured only by such means, and that, while Great Britain need fear no United States aggression upon Canada, the steady expansion of the United States portended no good; and he again predicted, as a result of expansion, civil war in the United States which might or would involve British interests also. This is not Aberdeen's first prophecy of civil war in America, but it is, perhaps, the first time that he made it an excuse for British policy. His elaboration of British policy was thus clearly stated, in order, he wrote Elliot, "to demonstrate to you that the mystery which you unfortunately threw around your recent proceedings was not only unnecessary, but liable to be misconstrued in such a manner as to make our policy appear in a light the very reverse of that which it ought to bear."

When, late in June, the news reached Mexico of the Jones proclamation in Texas and of the calling of the convention, the period of complacent elation over the results of Elliot's mission was followed by deep depression. Bankhead's earlier rejoicing at his own efficiency in Mexico was dampened by his recognition of the absolute futility of the enterprise to forestall American action. Still, he pressed Cuevas to issue a proclamation similar to that of Jones, calling for a cessation of hostilities. The news from Texas, however, inspired in Cuevas sentiments neither magnani-

${ }^{2}$ F. O. Texas, 2I, Aberdeen to Elliot, July 3, 1845 . 
mous nor docile, and instead of consenting to a cessation of hostilities, he resorted to vehement and excitable bluster and threat. Bankhead's demands for peace he met with threats of war. ${ }^{3}$

The Texas convention in response to the call of President Jones met early in July, rejected peace with Mexico upon the basis of independence, and on July 4, 1845, committed Texas to annexation. The final formal agreement was deferred until February, I846, but the vote of July 4,1845 , determined the future of Texas conclusively. News of this action reached Bankhead at about the same time as Aberdeen's instruction of May 3 which outlined the policy of joint British and French action. This instruction from Aberdeen was withheld owing to the altered conditions in Texas. Bankhead later excused the suppression of the instruction by the statement that England might be compromised by its presentation. 'Aberdeen had written that should Mexico refuse to acknowledge Texan independence, she "would thereby forfeit the assistance and good-will of England." Bankhead held that Mexico might insist that the converse of the proposition made England liable for assistance inasmuch as Mexico had twice yielded to Great Britain. Having formally consented to a peace with Texas upon the basis of independence, "Señor Cuevas might lay hold of such an acquiescence by insisting upon our now aiding Mexico in her quarrel." 4 This seems a forced and most unlikely interpretation of British responsibilities. Almost every message from the foreign office of the previous two years had carefully and explicitly stated that England would not aid Mexico by force

${ }^{3}$ F. O. Mexico, 185 , Bankhead to Aberdeen, June 29, 1845.

'F. O. Mexico, I86, Bankhead to Aberdeen, July 30, 1845 . 
of arms. The instructions to Bankhead had repeatedly expressed these intentions with ever increasing emphasis, and Aberdeen was in no way committed to more than the moral support which his letters had promised.

After the vote of the Texan convention in July of I845 was known in England, the whole matter was regarded as finally and irrevocably settled. When, as before mentioned, it was learned that Elliot had abandoned his post in Texas, he was ordered to return to it at once. He was reproved and explicitly directed to stay in Texas and maintain his position as a representative of the dignity of the British nation until the country should become a corporate part of the United States. When the formalities of annexation were concluded, he was to close his office and return to England. ${ }^{5}$ In the last month or so of his stay, however, Elliot was more occupied in meeting the American attacks occasioned by his secret mission and with his own defense before Aberdeen than he was with the dignity of England or the affairs of Texas. Letters from Buchanan to Donelson, reflecting upon Elliot and talking much of his secrecy, had appeared in the New York Herald in December of 1845. Much of Elliot's time and energy were given to defending himself to Aberdeen against the charges in these newspaper attacks. ${ }^{6}$

${ }^{5}$ Elliot was instructed to bring with him all the records of his office. Thus the manuscripts in the Public Record Office contain all of this correspondence, in addition to the correspondence ordinarily found between the foreign office in London and the ministers abroad.

${ }^{6} \mathrm{~F}$. O. Texas, I6, Elliot to Aberdeen, January 8, 1840. Newspaper comment at the time of Elliot's mission had 
The Texan matter was ended. Texas for a short time longer stood on her own feet, but she was committed to her future, and direct British interest and interference were things of the past. Both Aberdeen's and Elliot's letters show that no further step was contemplated, and that they accepted the inevitable. They were none the less confident of the honesty and sincerity of Houston, Jones, and Smith. At no time did they doubt them, and they regarded the probable election of Houston and Jones to the United States Senate as in a measure a proof that Great Britain had attempted no unwarranted interference in Texas. At the same time, neither Elliot nor his chief was hopeful of the future of Texas; they predicted that annexation boded ill for the people, and Aberdeen's prophetic vision saw disintegration of the Union as well.

While Texas was waiting, things were happening in Mexico, and England was not permitted to wash her hands entirely of Mexican affairs. As war with the United States became more and more probable, the Mexican government turned again to Great Britain for aid. Aberdeen never varied from the position he had assumed in the last months of 1844 , and uniformly refused any aid to Mexico. On June I, I846, he wrote to Bankhead, positively declining any support to Mexico, and stating that it had been British policy for the last three years to refuse such support and that each year had seen better reasons for adhering to such a policy. He summed up the situation in very terse language:-

been excited by references to the presence in Mexico of the "man in the white hat," and Elliot, much to his disgust, was now identified with this person. 
It is moreover obvious that, were Great Britain to interfere in that quarrel, she would involve herself in a war with the United States; and not only that, but she must necessarily play the part, not merely of an auxiliary, but of a principal, in such a war; that is, she would find herself engaged in a war with a Nation with which she would have no personal cause of quarrel, in behalf of a Nation and Government which she had repeatedly warned in the most friendly and urgent manner of their danger, and which, solely in consequence of their wilfull contempt of that warning, have at last plunged headlong down the precipice from which the British Government spared no efforts to save them."

This note was not to be communicated to the Mexican government, but Bankhead was instructed to make it the basis of his answer to that government. The reasons for British policy and the argument which Aberdeen was now prepared at all times to advance in support of that policy were forcibly and simply stated. At this time Aberdeen knew that the Oregon question was approaching a peaceable solution, and he was also aware of the probable fall of his government. The soothing influence of a happy solution of the Oregon question, which had threatened pacific conditions for a short time, was perhaps reflected in England's attitude in this matter. British support to Mexico in a war with the United States could not be accorded immediately upon American concessions to England in the northwest boundary dispute. Prospective retirement from office may also have caused Aberdeen to leave behind him this final statement, outlining a concise defense of his entire policy with regard to Mexico. In July of 1846 Lord John Russell became prime minister of England, and Palmerston once more returned to the foreign office.

${ }^{7}$ F. O. Mexico, 194. 
While there is nothing to add to the facts already stated in this study of British-Texan diplomacy, it may not be amiss to call to mind briefly some of the points narrated, and perhaps thereby get a clearer general view of the sequence of events with their causes and effects. While this study begins properly in 1839 , Texas had separated itself from Mexico in 1836, and beginning even earlier than that the strength of Mexico as a concrete nation had steadily waned. Whether or not there was general recognition of the fact in England, it is true that British support of the government of Mexico, which had become almost a tradition in the foreign office, was losing popularity. The manifest weakness of Mexico may account for this in part; then, too, the realization that England's future was not dependent upon Mexican adherence in the question of balance of power in the New World had its weight as well. The time had gone by when British prestige or power were augmented by either the trade or the friendship of Mexico.

To recapitulate, England at first took little interest in the revolt of Texas, but when British agents in America called Palmerston's attention to the new republic, and assured him that it could never be reconquered by Mexico, he looked into the situation. This new country, peopled by men of Anglo-Saxon ancestry, made its own appeal; once independent and strong, it would be an ally and its friendship would be worth cultivating, and the opportunity to assist in its development attracted Palmerston. The existing relations between Great Britain and the United States, while friendly, were hardly upon a perfectly reliable basis while such matters as the northeastern boundary, 
right of search or visit, and others were unsettled. If, in the inevitable adjustment of these matters, friction should result, as would be more than likely, what more advantageous for England than a friend to the south of the United States border? Texas, in her ambition for independence and power, might act as a check upon the United States. Doubtless such sentiments and reasoning led up to the signing of the Hamilton treaty, which was the first important step taken by England involving the recognition of Texan independence and an admission of her value to England.

Following the impression that Texas first made upon the British horizon, internal political changes in England and Mexico and a little later in the United States altered the direction of affairs. The change of government in Mexico was of little importance, so far as Mexico was concerned, in Mexican relations with the outside world; but in England the fall of the Melbourne ministry brought with it a different foreign policy. When Aberdeen succeeded Palmerston, conservative tendencies led to a renewal of the earlier relations with Mexico, and he directed British diplomacy in support of the Mexican Republic. With the election of Harrison and Tyler, friendship for the United States, which was to come first under Aberdeen, seemed more possible, and future British security demanded the cementing of such ties, so that in the new Peel administration Texas was a less important item. Indeed, Texas had been discredited in a measure by Hamilton's duplicity in the matter of the delayed treaty ratification, and the State could the more justifiably be forced into the background. It is hardly 
necessary to say, however, that any real British apprehensions of annexation would have dictated a different policy. Neither Palmerston nor Aberdeen appreciated any danger in that direction, nor, indeed, did they consider its possibility.

The incidents in connection with the "Guadeloupe" and the "Montezuma," in which Aberdeen's action betrayed the uncertainty of his policy, which it must be admitted, had a distinct leaning toward Mexico, were succeeded by Ashburton's errand to America and the conclusion of the treaty. This treaty, after all, failed to satisfy England. Much had been hoped from Ashburton's mission, and something had been accomplished. Nevertheless, the feeling prevailed that a satisfactory adjustment of difficulties had not resulted, and that the United States herself presented the first hindrance to those desirable, permanent, friendly relations which England sincerely hoped to see established. With the disappointing conclusion of the Ashburton treaty and the consequent check upon the friendly advances of Great Britain, Aberdeen's attention was once more directed to Texas. Kennedy's reports and Ashbel Smith's arrival in London served to strengthen Texan interests at this time, and the policy which earlier ignored the importance of Texas was gradually directed toward maintaining the friendship of both that State and Mexico. England discharged the obligation involved in the treaty with Texas by urging Mexico to make peace with the revolted province, but the British ministry declined a part in the tripartite intervention, sent Elliot to Texas without instructions indicating British policy, and was not at all concerned with the possibilities of annexation by the United 
States. 'As the year I843 proceeded, however, the ineffectiveness of the Ashburton Treaty became more apparent. A dispute arose as to the interpretation to be placed upon the eighth article of that treaty in regard to a joint cruising squadron therein provided for the suppression of the slave-trade on the African coast. President Tyler attempted to interpret that article to include a renunciation by Great Britain of the offensive British claim to a right of search or visit. Aberdeen was forced to deny officially and in Parliament that Great Britain had given up any asserted right in this connection. Such incidents were naturally provocative of irritation in England, and their occurrence was a severe test to a peace policy, however positive and determined.

In the summer of 1843 occurred the abolition convention in England and Aberdeen's conference with the committee which urged upon him the necessity for effort on the part of Great Britain to bring about abolition in Texas. Up to this time, in spite of Elliot's persistent pleadings, Aberdeen had taken no official notice of the institution in Texas, but with the revival of the antislavery agitation in England he was induced to press for abolition through Mexico, hence the armistice plan, which Aberdeen seconded while wholly ignorant of annexation plans maturing under Tyler and Upshur in the United States. It was Aberdeen's misfortune, as it was Tyler's good luck, that these measures were undertaken at about the same time. The opportunity to publish British intentions in regard to Texas and to interpret these to mean interference with a national institution was precisely what was needed in America to solidify American support 
of annexation. British interest in and for Texas could be interpreted to mean British interference and intrigue, and most bitter anti-British sentiments were aroused. The sensational newspaper reports were a revelation to Aberdeen, but astonishment soon gave place to anger at the injustice of the charge, and later still to anxiety, as the inevitable conclusion forced itself upon him that back of the attack made upon him by the United States was the definite plan to annex Texas.

Aberdeen's official denial of any intention to interfere with slavery in the United States was formally presented through Pakenham. His emphatic disclaimer in regard to abolition, when viewed in the light of his future plans for Texas, is more interesting for what it left unsaid than for its announcement of policy. Probably Tyler's plans for annexation were no more clearly formed and definitely determined upon than was Aberdeen's carefully worked out scheme to defeat annexation at the very time he was focusing public attention on his denials in regard to abolition. His proposal of joint action to France in January, I844, outlined a well-balanced, well-developed plan to which he trusted for success. In its application the use of force, if necessary, was implied, but British confidence in British powers of prohibition was such that it was never for a moment contemplated. When Pakenham's illuminating letter came which showed how far wrong Aberdeen was in his reckoning, and that war would certainly follow if the plan were undertaken, England could not too soon find a way of escape. Aberdeen's transference of Pakenham's despatch to Guizot, with an accompanying suggestion of delay until after the American presidential election, 
prepared the way for French withdrawal, and Bankhead's report of Santa Anna's warlike intentions, received at about the same time, opened another avenue of escape to 'Aberdeen. Santa Anna's blustering, stupid threats in this connection gave excuse for Aberdeen's arraignment of Mexico and for his assumption, before the fact, that she would not grant Texan independence. British-French action, being dependent upon Mexican compliance, was assumed to be a failure since Mexico proposed to reconquer Texas rather than sign a treaty of peace. Without waiting for an acknowledgment from Mexico of the joint intervention project itself, Aberdeen presupposed Mexico's refusal, and felt himself and England absolved from all further responsibilities toward Santa Anna's government. Later came Guizot's statement that French cooperation in intervention would not go to the point of war, and England's anxiety was over. In the six months intervening between the receipt of Pakenham's message in June and the final announcement of French withdrawal in December Aberdeen's belief in the helplessness of Great Britain to avert the annexation of Texas had become a settled conviction.

The events of the year 1845 in regard to Texas are almost in the nature of anticlimax. The year I844 saw the culmination of arrangements of preceding years; in the United States preparation and education for annexation were carried through to completion and the presidential election resulted favorably to the cause, while in England the government resigned itself to the inevitable. Elliot's enterprise of 1845 , futile in results as it was, was permitted, not instigated or directed, and success was not anticipated. Aberdeen's 
instructions at this time were concerned with limiting British energies rather than encouraging them, and indeed these activities were permitted only on the slight chance that Texas herself might refuse annexation at the last. The difficulties of Aberdeen's program had their origin in his effort to put nearly equal emphasis upon two naturally conflicting points of policy. The first point was the maintenance of peaceful and friendly relations with the United States; the second, which, in the development of his policy, had ultimately to be sacrificed to the first, was the restriction of the United States to its then boundaries. That he believed he could maintain unruffled peaceful relations with America while British efforts were constantly directed to checking American expansion to the south and west seems something of an anomaly. Yet it was in pursuance of this policy that Aberdeen's negotiations regarding Texas were undertaken. Texas was an independent country, though adjacent to the United States; that country had been the first to recognize its independence; and England's privileges in Texas were just such as she had in Mexico or in any other independent republic. In so far as Texas stood upon her own feet uncompromised by pledge or agreement with any other nation, England's efforts to secure influence beneficial to British trade were perfectly legitimate. Neither was there any violation of international ethics in a straightforward attempt to bring about abolition in this young republic. Criticism of Aberdeen's action was rather centered upon his lack of frankness and his unaccustomed use of devious ways.

What might have been the final result in Texas had 
Palmerston not given place to Aberdeen it is difficult to conjecture. With less stress upon the friendship of the United States, and with the less conservative, more adventurous temperament of the earlier minister, British policy might have been so directed as to threaten peace. But British policy with Texas was essentially Aberdeen's pacific policy, and England's peaceful acceptance of the fact of annexation was also dictated by Aberdeen. In order to circumvent the United States in her project for annexation, Aberdeen expended his best energies, but nothing was undertaken which involved any break in existing harmonious relations. His resourcefulness was taxed to devise a measure promising success which should not involve England in war. The checking of United States expansion was a thing most desirable in itself; an independent Texas might greatly benefit England; but the independence of Texas, in Aberdeen's eyes, was practically a negligible consideration when weighed against war with the United States. The spirit of the nation, his own preference, and the integrity of British diplomacy demanded the continuance of peaceful relations with America. 


\section{CHAPTER XI.}

Addendum. English Interest in the Annexation of California.

In the opinion of contemporary British diplomats the situation in California was intimately connected with events in Mexico and Texas, and British agents, prophesying the destruction of the Mexican state, frequently advocated the acquisition of California as some compensation for American expansion in other directions. It is not apparent that this had any influence whatever in directing British policy in Texas. On the other hand, the changing situation in that State had a direct bearing on the activities and desires of British agents in California and, in much less degree, on the inclinations of the foreign secretary in London. For this reason permission has been obtained to append the following chapter on "English Interest in the Annexation of California" as it appeared in the American Historical Review. ${ }^{1}$

All histories treating of the Pacific Coast devote much attention to the question of English interests in, or designs on, California during the period from 1838 to 1846 . In any brief treatment of this subject only the more important points can be considered, and this

${ }^{1}$ The substance of this paper was presented before the meeting of the Pacific Coast Branch of the American Historical Association, at Berkeley, California, November 21, 1908, and was printed in the American Historical Review, Vol. XIV, July, 1909. 
article is therefore confined to the larger aspects of the case customarily stated by historians. When the various suspicions directed against Great Britain are summarized, they are found to deal with three points: first, a mooted transfer of California to the English bondholders of the Mexican debt, with the ultimate object of making California a colony of Great Britain; second, a project for the immediate and direct transfer of California to England by sale or gift from Mexico; and third, specific instructions to British admirals upon the Pacific Coast looking toward the accomplishment of these designs. Until very recently it has been possible to meet general assertions of such designs with merely negative evidence. Now, however, by the recent opening to research of the records of the British Foreign Office to 1850 it is possible to determine whether or not English foreign secretaries knew or cared anything about California. It is the purpose therefore of this article to state the results of an examination made into the documents preserved in the Record Office in London with special reference to the question of British designs upon California, ${ }^{2}$ for it is

${ }^{2}$ The records thus examined covered the period from 1838 to 1846 inclusive, and were found in the series of despatches to and from the diplomatic agents, both ministers and consuls, in America, Mexico, and after I84I in Texas. In addition, search was made in the Admiralty Records for the same period, although these are by no means complete, owing to the destruction by an official at the Admiralty Office of the greater portion of the despatches of the Admiralty of this period-a destruction covering not merely the Admiralty Letters to and from the Pacific Coast, but Admiralty Letters from stations all over the world. It was, however, possible, in the lack of the letters themselves, to use for these years the "Digest and Précis" of Admiralty Correspondence, which gives in condensed form the substance of each letter sent out or received. 
certain that if any definite plans ever existed upon the part of the English government, or were even favorably received by English ministers, they would find some place in British contemporary correspondence.

Dismissing as incompetent the various rumors of the time and confining attention to the evidence from the Record Office, it appears that the very first manifestation of British interest in California resulted from the arrest of English and American citizens in Monterey. This occurred in April, I840, for an alleged conspiracy intended to overthrow the authority of Governor Alvarado. ${ }^{3}$ These foreigners, some two score in number, were transported to Tepic, under the charge of Josef Castro, and there claimed the protection of Barron, the British vice-consul. In his report upon the incident to Pakenham at Mexico, Barron, while taking the necessary steps to secure indemnity for the "injustice" done to British subjects, was nevertheless primarily concerned that no British ship of war was at hand to be despatched to Monterey. He was in fact compelled to appeal to the commander of the United States corvette "San Luis" and to entrust to him the investigation of the causes of the trouble in California. In the subsequent correspondence on the adjustment of the difficulty much praise is given the American commander for his prompt and generous services, ${ }^{4}$ but the necessity for such aid irritated both Barron and Pakenham, and both men urged an increase of naval strength in the Pacific. ${ }^{5}$

${ }^{3}$ F. O. Mexico, 136, Barron to Pakenham, May 12, I840.

'Ibid., I37, no. 78, Pakenham to Palmerston, August 22, I840.

'Ibid., 136, no. 65, Pakenham to Palmerston, July 5, 1840. 
In the beginning, then, Pakenham was interested solely in the question of British naval prestige, and there is no evidence that he had any real knowledge of the situation in California. Soon after this, however, he received several communications from Barron stating the great value of Upper California, and about the same time he had an extended conversation with one Forbes, who had been a resident of Monterey. ${ }^{6}$ Also, Pakenham learned of the journey through California of a Frenchman, Duplot du Morfras, and apparently became somewhat suspicious of French designs upon the Pacific Coast. The result was that on August 30, I84I, he addressed a despatch to Palmerston, advocating a plan which should ultimately secure California to Great Britain. ${ }^{7} \mathrm{He}$ wrote:-

It is much to be regretted that advantage should not be taken of the arrangement some time since concluded by the Mexican Government with their creditors in Europe, to establish an English population in the magnificent Territory of Upper California.

He then stated the terms of an agreement concluded in 1837 between the Mexican government and the British bondholders of the Mexican debt, by which it had been arranged that in place of a repayment in cash to the bondholders they were to be permitted to locate lands within the boundaries of the Mexican state, to colonize them, and to receive revenues from them. Some few attempts had been made and plans put forward to realize this scheme, and the Mexican government had offered to allot a large quantity of such

'Ibid., I45, no. 43, Pakenham to Palmerston, June Io', I84I.

'Ibid., I46, no. 91, Pakenham to Palmerston. 
lands in the province of Texas. Meanwhile, however, Texas had risen in revolt and had thrown off Mexican authority, so that the proposal seemed absurd to the bondholders, and it was now desired to find lands elsewhere that might be thus organized. Pakenham continued:-

... as relates to Texas, the arrangement must of course, be considered a dead letter; and in the present circumstances of the Country, Chihuahua, and New Mexico are not eligible districts for colonization: but I believe there is no part of the World offering greater natural advantages for the establishment of an English colony than the Provinces of Upper California; while its commanding position on the Pacific, its fine harbours, its forests of excellent timber for ship-building as well as for every other purpose, appear to me to render it by all means desirable, in a political point of view, that California, once ceasing to belong to Mexico, should not fall into the hands of any Power but England; and the present debilitated condition of Mexico, and the gradual increase of foreign population in California render it probable that its separation from Mexico will be effected at no distant period; in fact, there is some reason to believe that daring and adventurous speculators in the United States have already turned their thoughts in that direction.

He then gave details to show that it would be easy to form a company in England "for the establishment of an English colony in California," and to prove its certain success as a business venture :-

If it were to be known that an enterprise of this kind would receive the sanction and support of Her Majesty's Government, properly qualified persons would readily be found to carry out the plan; and I am sanguine enough to believe that the result would be the establishment of a prosperous colony united in feeling and interest with England, and at the same time the attainment of an object, in my humble opinion, of the highest political importance. I need scarcely observe that any foreign Settlement in California would for some time to come be nominally dependent on the 
Mexican Republic; but this state of things would not last forever, nor, while it did last, would it, I imagine, be attended with serious inconvenience.

If it were to be understood that Pakenham here reflected English governmental opinion, it would be certain that England was looking forward to the breaking-up of Mexico, and that she was not averse to profiting by the disturbance. In reality, Pakenham merely stated his own opinion-an opinion evidently moulded by Barron and Forbes. Certainly, it must have appeared to the British cabinet that its agent in Mexico was pursuing a curious policy in thus coolly planning for the ultimate seizure of a part of that state at a time when his instructions ordered him to aid Mexico in every possible way in the establishment of a strong, united government. Pakenham himself did not believe that Mexico would ever be able to unite under a republican form of government and become a strong power, but his idea of the inevitable disintegration of the Mexican state was not as yet shared by his superiors at home. His recommendation in regard to California had been addressed to Palmerston, but before his despatch could reach England a change of government had brought Aberdeen to the foreign office.

Aberdeen's reply promptly put an end to Pakenham's dream of a British colony in California. The latter's despatch had been referred to the colonial office, and the reply of Stanley from that office to Aberdeen was now transmitted to Pakenham without comment from the foreign office:- ${ }^{\mathbf{8}}$

${ }^{8}$ F. O. Mexico, I43, no. I3, Aberdeen to Pakenhain, December I5, I84I, and ibid., I5I, Dom. Var., G. W. Hope to Viscount Canning, November 23, I84I. 
His Lordship directs me in answer, to acquaint you for the information of the Earl of Aberdeen, that he is not anxious for the formation of new and distant Colonies, all of which involve heavy direct and still heavier indirect expenditure, besides multiplying the liabilities of misunderstanding and collisions with Foreign Powers. Still less is Lord Stanley prepared to recommend the adoption of a plan whereby the Soil shall, in the first instance, be vested in a Company of Adventurers, with more or less of the powers of Sovereignty and of Legislation, and the Settlement so formed be afterwards placed under the protection of the British Crown; which as it seems to his Lordship is the position contended for by Mr. Pakenham.

This reply is, in truth, a concise statement of the entire British attitude at the moment and represents the almost unanimous opinion of English statesmen that the day for colonial enterprise had passed. Such opinion is illuminative of British policy as regards both home and colonial politics, and to neglect it would be totally to misunderstand those conditions in English government at the moment which practically negative any suspicion of British designs for expansion in any new territory, wherever that territory might be located.

Pakenham perfectly understood the indifference of $\rightarrow$ Great Britain to his plan and he himself at once lost interest in it. In fact, he even neglected to appoint a vice-consul at Monterey at the time, permission to do this having been previously granted to him, ${ }^{9}$ and it was not until after Commander Jones of the American navy performed his spectacular feat of seizing and releasing the Port of Monterey, in the fall of I842, that Pakenham bestirred himself to appoint a British agent there. The man appointed was James Forbes, who was to act as vice-consul, and who was to be sub-

${ }^{9}$ F. O. Mexico, I43, no. 6, Palmerston to Pakenham, February $26,184 \mathrm{I}$. 
ordinate to Barron, located at Tepic, on the Gulf of Lower California. ${ }^{10}$ Upon these two men Great Britain depended for intelligence and advice regarding California, although other sources of information were available for it was in this same year that Sir George Simpson wrote his impressions of California and transmitted them in letters to officials of the British government. $^{11}$ Like Simpson, Barron and Forbes were confident that it would require but little activity on the part of the British Government to secure California. Throughout 1843 their reports were numerous, ${ }^{12}$ con-

${ }^{10}$ F. O. Mexico, I55, no. I20, Pakenham to Aberdeen, December 25, 1842. The appointment of Forbes was made immediately after Pakenham heard of Jones's act at Monterey. This act was reported by Pakenham in his no. II9, of the same date as the preceding.

${ }^{11}$ The most important of Simpson's letters were published in the number of the American Historical Review for October, 1908, and need not be expanded here. It is interesting to note that about the time of Simpson's letter, Ashburton, who was negotiating the Treaty of Washington, was writing of a hint made to him by Webster that the United States would yield somewhat in the Oregon matter if Great Britain would acquiesce in the American occupation of California. Ashburton also expressed his disbelief in the value of California, for a long time to come, to the United States or any other power. Ashburton's letter is also of interest in view of Webster's later denial that he had ever made such a proposal, F. O. America, 379, Ashburton to Aberdeen, April 25, I842.

${ }^{12}$ F. O. Mexico, 156, Admiral Thomas to Barron, Valparaiso, August 12, 1842; Barron to Aberdeen, December 7, 1842, and again December 20, 1842; ibid., I6I, Barron to Pakenham, December 20, I842; ibid., I65, Doyle to Aberdeen, December 30, I843; ibid., I67, Barron to Admiral Thomas, January I8, 1843; Barron to Aberdeen, April 15, and September 9, I843; Forbes to Barron, October 19, 1843; ibid., 179, Barron to Aberdeen, January 20, 1844 . 
taining frequent and suggestive allusions to American designs upon California, and so somewhat adroitly paving the way for a definite proposal. This, in I844, Forbes was prepared to submit, although even here the proposal was thinly veiled in the form of a request for advice. This plan, originating with Forbes in September, was transmitted by Barron to Aberdeen on October I2, 1844, and it was received in London on December I3, a date which it will be important to remember later in estimating the reply made by Aberdeen. ${ }^{13}$

On September 5 Forbes had reported to Barron the circumstances of an interview with a body of influential native Californians. These men asserted that the Mexican government had reached such a state of inefficiency that they were planning to revolt in order to establish an independent government. After describing all the evils which California had suffered under the misrule of Mexico, Forbes was asked "whether this country [California] can be received under the protection of Great Britain, in a similar manner to that of the Ionian Isles, but to remain for the present under the direct Govt. of one of its natives though under the same form as the Govt. of that $\mathrm{Re}$ public." The reply of Forbes was that he was "entirely unauthorized" to enter into any such affair. The deputation assured him that their only desire at present was that he act as "an organ of communication with the English Government. If he would do this, his correspondents would quietly await until he should learn the pleasure of H. Majesty's Government." Forbes reported to Barron that he had been

${ }^{13}$ F. O. Mexico, I79. 
most careful not to compromise the English government in any way, and that he certainly would not meddle without authority, but he added:-

I feel myself in duty bound to use all my influence to prevent this fine country from falling into the hands of any other foreign power than that of England. I repeat that it is impossible for Mexico to hold California for a much longer period, and if the Govt. of Great Britain can with honor to itself, and without giving umbrage to Mexico, extend its protection to California, reaping those benefits which by proper management, would infallibly attend that protection, I should presume that it would be impolitic to allow any other nation to avail itself of the present critical situation of California for obtaining a footing in this country.

In this connection Forbes stated that there were several standing offers of French protection, giving as his authority the word of native citizens of California. $\mathrm{He}$ mentioned $\mathrm{Du}$ Morfras as being the agent in one of these offers of French protection, but added that at the time the offer was made the people were not so ready to act or so united in sentiment as they now were: Forbes also stated that if Great Britain was at all interested in the project of a colony upon the $\mathrm{Pa}$ cific Coast no reasonable comparison could be made between Oregon and California, thus indicating that he, like Barron, thought that possibly an arrangement might be made by which British interests in Oregon could be exchanged for a position in California. Barron made no detailed comment upon this report, but in transmitting it stated:-

I shall of course caution him most earnestly not to interfere in any manner of way in the promotion or conduct of any revolutionary proceedings, and I am sure such will be his conduct. It is not for me to express any opinion on the subject of Mr. Forbes' despatch, otherwise than to say, that this fine country has been totally neglected by Mexico, and 
she must ere long see some other nation its protector, or in absolute possession of it.

In the light of later events the plan proposed to Forbes and reported by him to the British government may seem of no moment when compared with the energy displayed by the United States, but the incident is of the greatest importance in this account because the report of Forbes brought out the most direct and positive instruction given by the British government in regard to California throughout the eight years from 1838 to 1846 . Before stating Aberdeen's reply, however, it is necessary to explain the conditions existing with regard to other Mexican interests at the exact moment when the report of Forbes reached the British foreign office. These conditions are peculiar, for the month of December, I844, records a strange lapse in the otherwise consistent attitude regarding Mexican relations-a lapse which was strictly temporary (lasting less than a month) and wholly explainable. The situation was this: in the spring of 1844, after it became evident that the United States was actually planning for the annexation of Texas, Aberdeen became greatly exercised over the possibility of such an expansion of the American State. He sought in various ways to bring about an international situation which should prohibit such an annexation. He instructed Elliot, the British chargé d'affaires in Texas, to use all his influence against a Texan acquiescence in the projects of the United States. ${ }^{14}$ He urged upon Mexico the necessity of immediately recognizing the independence of Texas in order that by some sort of joint diplomatic ${ }^{14}$ F. O. Texas, 20. 
action, France, Mexico, and Great Britain might guarantee the independence of the Texan State. ${ }^{15}$ The British ambassador at Paris, Lord Cowley, was actively seeking the consent of France to this plan and supposed that he had secured it. ${ }^{16}$ Pakenham, who was now the British minister at Washington, was instructed to act cautiously yet with decision in the matter. The complete details of the negotiations looking toward this end are too minute to be given here, but in substance it may be said that one element in the failure of the plan was the stupidity and obstinacy of Mexico, which could not bring itself to yield to British advice and to recognize the independence of Texas. Time after time, acting under instructions from Aberdeen, Bankhead, the new British minister at Mexico, pressed upon Santa Anna the necessity for a prompt and speedy recognition of Texas. The answer returned to him in every instance was that an army was now being gathered in Mexico for the immediate reconquest of that province. ${ }^{17}$ Neither Bankhead nor Aberdeen believed that Santa Anna really thought the reconquest of Texas a possibility, and Aberdeen was angered at the refusal to follow his advice and play Great Britain's game. In the summer of 1844 Pakenham reported his conviction that

${ }^{15} \mathrm{~F}$. O. Mexico, I72, no. I6, Aberdeen to Bankhead, June 3, 1844; F. O. America, 403, no. 25, Aberdeen to Pakenham, June 3, 1844; F. O. Mexico, 180, Dom., report drawn up of interview between Aberdeen and Murphy, Mexican minister in London, May 29, 1844.

${ }^{16} \mathrm{~F}$. O. Texas, 20, copy of despatch, Cowley to Aberdeen, Paris, June $15,1844$.

${ }^{17}$ F. O. Mexico, I74, no. 44, Bankhead to Aberdeen, June 29, 1844 ; ibid., 175, nos. 65 and 62 , Bankhead to Aberdeen, August 29, 1844 . 
the United States, should it determine upon the annexation of Texas, would not be deterred therefrom even by a threat of war by England and France. ${ }^{18}$ This report was decisive in its effect on Aberdeen's policy, for he had no desire to carry opposition to annexation to the point of war with the United States. Nevertheless, he had already gone so far in overtures to France and Mexico that a formal withdrawal of the plan was not at once possible. On December 2 Cowley reported from Paris that France was becoming lukewarm in any project looking toward the guarantee of Texan independence. ${ }^{19}$ In the same week there came from Mexico a final report by Bankhead stating the utter impossibility of bringing the Mexican government to recognize the independence of Texas. The effect of all these altered conditions upon Aberdeen was an immediate change of attitude. ${ }^{20}$ Instead of making such effort to prevent impending annexation as would be consistent with his earlier position, he completely ignored the American question, turned against Mexico, and for some four weeks all his in-

${ }^{18}$ F. O. Texas, 20, copy of despatch, Pakenham to Aberdeen, Washington, June 27,1844 .

${ }^{19}$ Ibid., 20, copy of Cowley's no. 568, to Aberdeen, Paris.

${ }^{20}$ For the purpose of showing the causes of Aberdeen's action in relation to California it is sufficiently exact to specify December as the turning-point in Aberdeen's policy toward Mexico and Texas, but a more detailed explanation of all this correspondence will show that it was Pakenham's despatch of June 27 that caused the change. After receiving it, Aberdeen was fearful that his diplomatic manoeuvering might actually result in a war with the United States. The final refusal of France, in December, to act with England was a distinct relief to him, while the obstinacy of Mexico gave him the chance to throw all the blame on that state. For a more complete account of this episode, see Chapter VIII. 
structions to Bankhead indicate a determination to have nothing further to do with the defense of Mexican interests. This was the situation, then, when Forbes's report reached London on December I3. Up to this moment the honor of the British government had apparently been bound to a general support of Mexican authority and unity.

Now, however, Aberdeen could argue that Mexico's obstinacy offered a sufficient excuse for taking advantage of Mexico's weakness, in case that weakness should bring profit to England without specific British attack upon Mexican territory. Aberdeen's reply to Barron bears date of December 3I, I844, and deserves quotation at length, since, as before stated, it is the most definite instruction upon California emanating from the British foreign office throughout the entire period:- ${ }^{21}$

The present position of California is evidently very critical; and it appears to be pretty clear that unless the Mexican Government bestir themselves, an outbreak will in no long time take place in that Province, which may end in its separation from Mexico. Her Majesty's Government can have nothing to do with any insurrectionary movement which may occur in California; nor do they desire that their agents in that part of the world should encourage such movement. They desire, on the contrary, that their agents should remain entirely passive.

While California continues subject to Mexico it would be obviously contrary to good faith on the part of England to encourage a spirit of resistance or disobedience in the inhabitants of the Province against their Mexican rulers. It is therefore entirely out of the question that Her Majesty's Government should give any countenance to the notion which seems to have been agitated of Great Britain being invited to take California under her protection.

${ }^{21}$ F. O. Mexico, 179. 
Her Majesty's Government do not pretend to determine as to the propriety of any step which may be taken by the inhabitants of California towards establishing their independence. In such matters no foreign nation has any right to interfere, except it be bound to such interference by Treaty with the Mother country; which is not the case with Great Britain. (It is, however, of importance to Great Britain, while declining to interfere herself, that California, if it should throw off the Mexican yoke, should not assume any $>$ other which might prove inimical to British interests. It will therefore be highly desirable that at the same time that it is intimated to the persons of authority in California that the relations which exist between Great Britain and Mexico prevent us from taking part in any proceedings of the Californians which may have for their object the separation of that province from Mexico, those persons should be clearly made to understand that Great Britain would view with much dissatisfaction the establishment of a protectoral power over California by any other foreign state.)

I do not think it necessary to enter into any speculative dis. cussion or opinions as to the possible future course of events with respect to California, but confine my observations and instructions to the aspect of affairs, and occurrences of the present moment.

Upon the same day Aberdeen wrote to Elliot in Texas notifying him of the failure of his plan for a diplomatic intervention, ${ }^{22}$ to Bankhead to the same effect and upbraiding Mexico for her acts, ${ }^{23}$ to Admiral Seymour on the Pacific Coast, ${ }^{24}$ instructing him to become more active in counteracting French designs upon the Pacific Islands; and again, a second letter to Bankhead in comment upon the letter just addressed to Barron, of which he enclosed a copy. This second letter to Bankhead stated even more

${ }^{22}$ F. O. Texas, 9, no. I3.

${ }^{23}$ F. O. Mexico, I72, no. 53 .

${ }^{24}$ Admiralty Secretary, In-Letters, no. 5544, Addington to Barron, December 3I, I844. 
clearly than the note to Barron the attitude now assumed toward Mexico and in regard to the situation in California. In it Aberdeen summarized the weakness of the Mexican government, and acknowledged that the separation of California from Mexico was probably inevitable. ${ }^{25}$ He then proceeded:-

It is however for the Mexican Government alone to take measures for providing against such a contingency; nor have we any ground for interposing to preserve California to Mexico, or to prevent that Province from asserting its Independence. We have, undoubtedly, no right to excite or encourage the Inhabitants of California to separate themselves from Mexico; but if the Mexican Government chooses to be wilfully blind we should in vain attempt to enlighten them.

But it may be a matter of serious importance to Great Britain that California, if it shake off the rule of Mexico, should not place itself under the protection of any other Power whose supremacy might prove injurious to British Interests.

Although, therefore, national integrity forbids us to give encouragement to the spirit of insurrection against Mexico which has evidently struck such deep root in the minds of the Californians, and still less to countenance the suggestion submitted by some of the principal Residents to Mr. Forbes with respect to the contingent Protection of their Province by Great Britain, it is not any part of our duty to supply the want of energy exhibited by their Natural Rulers, or to dissuade their subjects from taking any course, which, under a sense of misgovernment, they may think proper.

You will therefore abstain from touching on this subject with the Mexican Govt. and if any observations respecting it should originate with the Heads of the Govt. or the Secretary of State, you will use great caution and treat the matter with as much reserve as courtesy will permit.

But on the other hand you will keep your attention vigilantly alive to every credible report which may reach you of occurrences in California, especially with respect to the proceedings of the United States Citizens settled in that Province, whose

${ }^{25} \mathrm{~F}$. O. Mexico, 172, no. 53 . 
numbers are daily increasing, and who are likely to play a prominent part in any proceeding which may take place there, having for its object to free the Province from the yoke of Mexico.

These numerous letters, all bearing the same date, indicate the importance of the shift in British policy, and that this was, so far as Mexico, California, and Texas are concerned, a new policy from this moment. That it did not prove in the end to be a permanent policy was due to a rapid submission upon the part of Mexico and a resumption of former friendly relations with that state. Aberdeen as a man of honor, and as guardian of the honor of the British government, was opposed to authorizing any British agent to perform an act that might tend to stir up a revolutionary movement in California. $\mathrm{He}$ was not, however, unwilling to accept the fruits of that revolution if they should fortunately fall into British hands, and he was even willing to refrain from notifying the Mexican government that revolution in California was imminent. Such a passive policy was wholly inadequate to the situation. This was understood perfectly by British agents and by those close to affairs on the Pacific. While awaiting the reply from Aberdeen, $\checkmark$ neither Forbes nor Barron ventured to take any decided step to secure British interests, though both bet came more and more fearful of the speedy acquisition of California by the United States. In spite of the expulsion of Micheltoreno by Castro and of the incoming of numerous American immigrants, both men still thought a British protectorate could easily be secured if Great Britain would but express her will- 
ingness to assume such a protectorate..$^{26}$ But with the receipt of Aberdeen's instruction, May 26, their hopes of a British protectorate in the near future had to be abandoned. They were genuinely discouraged, but, hoping still to thwart American designs, they transferred their support to the Mexican government, believing that Mexican control would be more favorable to British interests than an independent government in California. ${ }^{27}$

The British agents in California therefore remained inactive, even largely ceasing to report conditions there, and it was not until Fremont arrived in the winter of $1845-1846$, nearly a year later, that Forbes was stirred to further action. The presence of Fremont was to him sufficient evidence that something was about to be undertaken by the United States to secure California. On January 28, I846, therefore, he addressed to Oliveria a protest against Fremont's presence "with Soldiers" in California, stating that ${ }^{28}$

in obedience to the commands of Her Majesty's Government, it is the duty of the Undersigned to state clearly and distinctly to this Departmental Government that while Great Britain does not pretend to interfere in the political affairs of California, she would view with much dissatisfaction, the establishment of a protectorate power over this country, by any other foreign nation.

${ }^{28}$ F. O. Mexico, 185, Barron to Bankhead, April 8, I845; ibid., I89, no. 3, Barron to Aberdeen, February 18, I845, enclosing a letter he had written to Admiral Seymour, January 28, I845; and no. 5, Barron to Aberdeen, April 19, I845, enclosing two letters received from Forbes, dated January 27 and March I0, 1845 .

${ }^{27}$ Ibid., I89, Forbes to Barron, October 24, 1845 .

${ }^{28}$ Ibid., 196, Forbes to Barron, January 30, 1846 (in Bankhead's no. 42). 
In assuming this authority to protest, Forbes clearly exceeded any authority given him from London, but he seems to have had no doubt as to the wisdom of his act or as to the approval of the home government. In the meantime events were moving rapidly upon the Pacific Coast, and before the reply of the foreign office could reach Forbes, Sloat had seized Monterey. Of this the foreign office was, of course, ignorant. A copy of this protest reached London in May, and Forbes was immediately disavowed by Aberdeen. On June I Aberdeen instructed Bankhead that while Her Majesty's government would no doubt view with dissatisfaction the presence of Fremont in California, ${ }^{29}$ ... they do not in any way approve of a British Vice Consul taking upon himself, without instructions from his Superiors, to address the Authorities of the Province in which he is residing a formal diplomatick note like that under consideration. I have accordingly to desire that you will signify to Mr. Forbes that Her Majesty's Government do not approve of his late proceeding, and wish that he should in future be more cautious in his conduct.

The reproof thus administered to Forbes came too late to have any effect upon his acts in California during the summer of 1846 . It is, however, clearly evident that Great Britain had no specific design or plan with regard to California when her foreign minister could promptly disavow so trifling an evidence of British activity as was Forbes's protest.

While British official agents in Upper and Lower California were thus definitely prohibited from direct interference in the movements in the province, other and less authoritative suggestions were being made to the government of Great Britain looking toward ${ }^{20}$ F. O. Mexico, I94, no. I6. 
its acquisition. Late in I844 McNamara, an Irish priest, appeared at the city of Mexico and laid before $\not$ Bankhead a scheme for the colonization of California by Irish emigrants. ${ }^{30}$ Bankhead expressed a mild interest in the plan and reported it to Aberdeen. No comment whatever, nor even an acknowledgment of its receipt, was made by that official. A more definite proposal, drawn up in specific detail and following in its main outlines the plan earlier proposed by Pakenham, was submitted to Bankhead in July, I845, by Mackintosh, a British consul in Mexico. ${ }^{31}$ Business partners of Mackintosh in London were also involved in this plan, but here again no attention was given at the foreign office, and no reply was made either to Bankhead or to the promoters. Besides the proposals of Mackintosh and McNamara there were many other suggestions from would-be statesmen or patriotic dreamers. Nevertheless, it is true that the proposal of Pakenham and the report of Forbes are the only two communications that were carefully considered or were officially met by the British government.

In spite, however, of the prohibition placed on British agents in California and of the lack of interest in private schemes of colonization, it is still conceivable that secret instructions were sent to British admirals of the purport of which British agents of merely consular rank would have no knowledge. In-

${ }^{30} \mathrm{~F}$. O. Mexico, 185, no. 52, Bankhead to Aberdeen, May 30, 1845. Bankhead did not report McNamara's scheme until some six months after it was broached.

${ }^{31}$ F. O. Mexico, 186, no. 74, Bankhead to Aberdeen, July 30, 1845. This plan is worked out in more careful detail than any other project submitted to the British government looking toward the acquisition of California. 
structions to admirals of the Pacific fleet have therefore been a subject of curiosity and suspicion to Americans. From the bare movements of the British ships on the coast they have tried to argue British governmental intention to acquire California. An examination of the letters to and from British admirals stationed on or near the Pacific Coast wholly negatives this suspicion and serves merely to emphasize the British government's lack of interest in California. During I84I-I842 Admiral Thomas, with headquarters at Valparaiso, wrote almost exclusively of the activities of the French in Tahiti, ${ }^{32}$ and the entire absence of any mention of California in his correspondence proves conclusively how absurd was Commander Jones's contention that one reason for the seizure of Monterey was a fear of British naval action. In 1843 this interest in the policy of France was greatly augmented. The French had seized the Friendly Islands, and Captain Paulet, of the British navy, took possession of the Sandwich Islands, where, however, native authority was very quickly restored under instructions from the British government. ${ }^{33}$ In I844 Admiral Seymour, now in command of the Pacific squadron, was still primarily interested in the question of the control of the Pacific Islands. Gradually, however, as a result of somewhat urgent letters from Barron at Tepic, he began to manifest an interest in California. Still, Seymour had to obey orders, and his orders were to

${ }^{82}$ Admiralty Secretary, In-Letters, no. 5512, Thomas to Admiralty Secretary, December 28, 184r. Also in same volume, Thomas to Herbert, April 23, 1842 . No. 5538, Captain Nicholas to Thomas, November 10, 1843 .

${ }^{33}$ Ibid., Out-Letters, no. 1696, Secret, Addington to Barron, July II, 1843 . 
watch the French. This, in fact, was the substance of the instruction received by him from Aberdeen, bearing date of December 3I, I844, an instruction of the same date as the many instructions sent to other officials in Mexico and on the Pacific Coast. ${ }^{34}$ Personally, Seymour never received any instruction directing him as to the policy he should pursue in regard to California, and for nearly a year he did not even know the contents of Aberdeen's instruction to Barron of December 3I, I844. When finally he did receive a copy of that instruction, late in 1845 , he perceived, as had Barron and Forbes, the merely passive policy enjoined upon British agents. Earlier in 1845 he had been directed to proceed to the Friendly Islands, ${ }^{35}$ and after some hesitation, because of his own feeling that the greater interest was in Oregon and California, he had gone to those islands by way of Honolulu. ${ }^{36}$ It was not until December, I845, that he again reached Valparaiso. Once arrived, he eagerly awaited new in-

"Admiralty Secretary, In-Letters, no. 5544, Addington to Barron (enclosing instructions to Seymour).

${ }^{35}$ Ibid., no. 5554, Addington to Corry, March 5, 1845; Admiralty to Addington, March 6, I845; Addington to Hamilton, March 8, 1845. Also, Out-Letters, no. 1646, Hamilton to Seymour, June I, 1845, urging immediate departure for Tahiti to watch the French.

${ }^{36}$ Admiralty "Digest and Précis," I845, no. I53 Y, letter from Seymour, July 3, stating that he cannot leave for Tahiti because of Oregon troubles, and letter of July I5, changing his decision and announcing his departure; Admiralty Secretary, In-Letters, no. 556I, Seymour to Corry, October 4, I845. The "Digest and Précis" contains for each year abstracts of all Admiralty Correspondence with British naval officers. Because of the destruction of the greater portion of the letters themselves for this period the "Digest and Précis" furnishes almost the only available material for study. 
structions as to Oregon and California, and at last, on March 6, I846, addressed a letter to the Admiralty urging an increase of his forces in the Pacific. ${ }^{37}$ This request was based on the belief that war with the United States was probable, and he specified the interests to be guarded in this order: first, to defend Oregon; second, "to observe the proceedings of the United States relative to California;" third, to protect British commerce on the coast of South America; fourth, to attack the commerce of the United States. The greatest stress was laid on the defense of Oregon, and detailed plans were given of probable operations on that coast. Seymour's request was couched in very vigorous language, and made evident his constantly increasing anxiety with regard to a recent increase of the United States naval force in the Pacific and the uncertainty as to what that might indicate. This anxiety was further shown by a letter from Seymour to the Admiralty, on April 7, written from San Blas, in which Seymour confessed that he had no knowledge of the whereabouts or intentions of Commodore Sloat, but suspected him of some movement toward Oregon. ${ }^{38}$ No reply was received by Seymour to any of these letters or requests previous to the actual seizure of Monterey by Sloat.

Shortly after this, early in May, Seymour sent Captain Blake with the "Juno" to California. Blake's action upon the Californian coast is well known and needs no comment here. He took Forbes on board his

"Admiralty Secretary, Out-Letters, no. I696, Corry to G. Smythe, June 10, 1846, transmitting to foreign office Seymour's letter of March 6.

${ }^{88}$ Admiralty Secretary, In-Letters, no. 556r. 
ship and sailed to southern California, where interviews were held with Pico, but both Blake and Forbes reported that in accordance with the instructions of Aberdeen they had limited themselves strictly to advising. Pico that he should not permit California to accept a protectorate from any foreign state. ${ }^{39}$ Meanwhile, Seymour, who was becoming daily more anxious for instructions, wrote on June I3 to Bankhead, the British minister at Mexico, that he had received information that the people of California were about to hold a convention at Santa Barbara to separate from Mexico and to seek protection from some other power. ${ }^{40}$ This movement, Seymour was informed, had originated in northern California, where partizans of the United States were strong. He stated:-

I have little doubt that I shall find the object of that power will be obtained, either by voluntary subjection on the part of the Inhabitants, or by the United States having taken possession of the Principal Port, in consequence of the recent hostilities with Mexico. Having however detached the "Juno" last month with instructions to Capt. Blake, if the Inhabitants of California declared their independence of Mexico, to endeavor to induce their leaders not to place themselves under the control or subjection of any Foreign Power, I think it my duty to call at Monterey to ascertain if the Inhabitants should have come to any resolution, which will facilitate the maintenance of their independence. My expectation is entirely to the contrary; but if the connection with Mexico, which appears to have been one of the principal

${ }^{30}$ Ibid., no. 5562, Blake to Admiralty, August 3, I846, enclosing two letters written by him to Seymour on July 5 and July I7; F. O. Mexico, 198, Bankhead's no. II2, enclosing two letters from James Forbes to Alexander Forbes, July 9 and I4, I846. The first letter was written just after the trip of Forbes and Blake to see Pico; the second, when Forbes heard of Sloat's action. Alexander Forbes was acting as consul at Tepic during Barron's absence.

${ }^{40} \mathrm{~F}$. O. Mexico, 197, in Bankhead's no. 91. 
causes of the non-interference of Her Majesty's Government shall have been removed, it seems desirable to ascertain the state of affairs, before it is acknowledged to be irremediable.

On the same day Seymour wrote to the Admiralty in much the same terms:- ${ }^{41}$

I have not, after the reports made by Captain Gordon and others to me, of the state of affairs on that coast, judged it advisable to proceed there, under the views expressed by the Earl of Aberdeen to Her Majesty's Minister in Mexico, deprecating interference, while California formed a part of the Mexican Republic; I however (as I have already reported) sent the Juno to Monterey and San Francisco on the IIth of May, with instructions to ascertain the Security of British Subjects, and observe what was passing.

I also directed Captain Blake, in the event of California declaring or having declared its Independence of Mexico, to use any influence he could obtain to counteract any inclination on the part of those in Authority to place themselves under the Exclusive Control or Protection of any Foreign Powers, without the participation of Great Britain; and gave him copies of Lord Aberdeen's Letters, (which I had procured since my arrival on this Coast) of the 3 Ist of December, 1844, to Mr. Bankhead and the Consul at Tepic, of the same date, for his information.

This contingency having occurred while I remain on the Coast, I deem it right, although I can form no very favorable anticipations of a satisfactory result, to proceed to Monterey, and ascertain the actual state of affairs; and it is my intention to sail from San Blas, for that purpose, this evening.

It is noteworthy that Seymour's indicated reason for the trip to Monterey is quite different from the one given after his arrival and the discovery of Commodore Sloat in possession. By the wording of Seymour's letter to the admiralty it is, however, positively certain that no instruction whatever had been received

${ }^{41}$ Admiralty Secretary, In-Letters, no. 556r, Seymour to Corry. 
by him or by the consular office at Tepic subsequent to Aberdeen's instruction of December 31, 1844, and it is therefore clear that Seymour was greatly hampered by the lack of more positive and recent instructions from London. Following the tenor of Aberdeen's despatch of December 31, I844, he was certainly limited to urging upon the people of California the maintenance of their independence, and there can be no doubt that he confined himself to this in the instructions which he gave to Blake. Blake's actions did not go beyond this in any respect. Seymour left on June I4 for Monterey, where, upon finding Sloat in authority, he gave out a statement to the effect that he had merely called at the Port of Monterey on his way to the Sandwich Islands. His report to Bankhead on July 22 is very brief and contains no comment or reflection on the United States. ${ }^{42}$ In the light of Seymour's expressions earlier in the spring of 1846 and of his request for an addition to his force on the Pacific there can be no doubt that he personally hoped to see some step taken toward the acquisition of California. In this he was of much the same mind as other British agents. His letters reveal that he was more anxious for such an opportunity than he was afterwards willing to confess. Nevertheless, neither he nor any other British agent felt free to undertake active operations to secure California to Great Britain, and all that can be said is that they were hoping for some fortunate chance that might permit them to forestall American plans while yet they maintained the purely passive attitude directed by Aberdeen.

${ }^{2}$ F. O. Mexico, 198. 
The fact that the government of Great Britain had very slight interest in California at this moment is seen in the answer given to Seymour's request for an increase of his force upon the Pacific. The official reply was prepared and forwarded at a time nearly identical with the seizure by the United States, but in complete ignorance of that fact. The admiralty transmitted the request to the foreign office, accompanying it with a statement that in case Aberdeen really wished to have a larger force in the Pacific the ships necessary for such increase would have to be taken from the home force, and in that event the naval force at home would be reduced below the power of the French. ${ }^{43}$ On this ground the admiralty objected to the granting of Seymour's request, unless the government was willing to find the money for an increase of the home force. In this connection the admiralty brought out the necessity of occupying at least two points on the Pacific, "one selected with reference to the French at Tahiti; the other with reference to the position the Americans are taking up on the N. W. Coast of No. America." $\checkmark$ This letter clearly proves that so far no instructions had been sent out by the admiralty for the occupation of Pacific ports, and if not sent by this time it is also evident that they would not be sent at all. The foreign office reply to the admiralty shows that Aberdeen had no fear of war, and hence was not in sympathy with the demand for an increase of force upon the Pacific. ${ }^{44}$ On June I9 Addington wrote:-

${ }^{43}$ Admiralty Secretary, Out-Letters, no. 1696, Corry to G. Smythe, June 10,1846 .

"Ibid., In-Letters, no. 5568, Addington to Corry, June 19, I846. 
The proposition of Sir George Seymour for an increase of force appears to Lord Aberdeen to be entirely founded upon the supposed probability of War with the United States, or with France, or with both Countries. Lord Aberdeen does not pretend to judge what amount of force may be requisite in the Pacifick for the general interests of the service: but if any material change should now be adopted, it ought, in his Lordship's opinion, to be the result of views of the policy which may be at present entertained by Her Majesty's Government upon this subject. Lord Aberdeen considers that whatever reasons may exist for rendering an addition of force necessary, the chance of war ought not to be taken as one, for of that he sees no probability.

This brief quotation from the foreign office reply to the admiralty contains the substance of the entire letter. Its tone indeed indicates surprise that the admiralty should ask for any large increase of force in the Pacific.

But one further incident concerned with English action in California requires mention. Although after $\checkmark$ I842 there were repeated rumors that Mexico had directly offered to sell or transfer California to Great Britain, the evidence already presented in this article $\checkmark$ furnishes sufficient proof of the falsity of those rumors up to I846. More direct testimony is, however, furnished when at last the offer was actually made. In the first months of I846 little attention was paid at Mexico to what was taking place in California, ${ }^{45}$ but when war with the United States apparently became

${ }^{45}$ Bankhead's interest was at this time greatly aroused by proposals, or suggestions, unofficially made by Mexicans of prominence that a solution of Mexican difficulties might be found in an overthrow of the republic and the establishment of a monarchy under a European prince. Bankhead was much attracted to the idea, and Aberdeen expressed friendly interest. The suggestion was not new, for similar plans had been in the air even as, early as 1837, and had even specified an Austrian prince. 
unavoidable anxiety rapidly developed as to the fate of $\checkmark$ California, and a plan was brought forward to place that province in the hands of Great Britain. After some preliminary interviews, Paredes, the Mexican president, officially proposed to transfer California to England as security for a loan. ${ }^{46}$ This offer was made in May, 1846, and in reporting it to Aberdeen, Bankhead stated, "It is an indirect offer of sale, and it is the first time that any such offer has ever been hinted at from a responsible authority." 47 This testimony is important in view of the persistent rumors of earlier offers. Bankhead was careful not'to express any opinion to Paredes of the probable action of the British government, and in transmitting the question to Aberdeen indicated doubt as to its importance. He did transmit it, however, and at the same time Paredes instructed the Mexican minister in London to press the affair officially. It is perhaps conceivable that such an offer, if made two years earlier, might have received some consideration by Aberdeen, but the time had gone when any such scheme was feasible, even if Great Britain had been favorable to it. Bankhead's despatch of May 30 containing the offer reached London shortly after a governmental political change, and $\checkmark$ it fell to Palmerston, who was again at the foreign office, to answer it. This letter, dated August I5, shows the new ministry adopting without material change the policy of the preceding government toward Mexico and the Californian question. ${ }^{48}$ Palmerston wrote:-

${ }^{46}$ F. O. Mexico, 197, no. 73, Bankhead to Aberdeen, May 30, 1846 .

${ }^{47}$ Ibid.

${ }^{48} \mathrm{~F}$. O. Mexico, 194, no. 4. 
If the Mexican President should revert to the above proposition you will state to His Excellency that Her M's. Govt. would not at present feel disposed to enter into any Treaty for the acquisition of California: and the more so, because it seems, according to recent accounts, that the Mexican Govt. may by this time have lost its authority and command over that Province, and would therefore be unable to carry into effect its share of any arrangement which might be come to regarding it.

The incident had in truth no direct bearing upon the question of British plans in regard to California, for the offer did not come until long after British policy was definitely determined. The importance of the facts just cited lies rather in the proof furnished that but one offer of sale was ever made by Mexico, and that not until May, 1846 .

The preceding account drawn from the available English documents in the Record Office is intended as a presentation of the most essential part of the evidence bearing upon the interests and intentions of Great Britain toward California. In estimating the extent of that interest and intention, it must always be borne in mind that at this time Great Britain had exactly as much right to acquire the province of California as had the United States or any other power. The possessor of the territory was Mexico, and Mexico alone had legal right to the country. When Americans made up their minds to occupy this province and took steps to secure it, they had no more claim to it than had British citizens. This fact is sometimes lost sight of, or is misunderstood by American writers. With them, the existence of any plan in the mind of a British agent upon the coast was in itself an offense against so-called rightful American claims. The idea 
is, of course, absurd. The plan of Forbes to acquire California is in itself no more blameworthy than the plan of the American consul, Larkin. In other words, precisely the same justification could be found for an English plan as for an American. It was equally right or equally wrong for either nation. In fact no such plan on the part of the British government ever existed. Restating again, briefly, the general results of this investigation, it is shown first, that there was a genuine and lively interest among British agents in securing California for England, if possible; second, that these agents acted wholly without instructions to this purport from their government, and were ultimately either checked or reproved for such slight openings as they effected.

Great Britain's lack of interest in California was probably due to a variety of reasons, among which (1) may be specified a general indifference to colonial expansion under any circumstances; lack of positive in(2) formation about California; the trying relations with (3) Mexico; and lastly and most important of all, the peculiarities of the Texas question, for here, in reality, (4/ lay the key to the whole situation. The only variation in her attitude of consistent passivity toward California appears in Aberdeen's instruction of December 3I, I844. That instruction was the result of a momentary irritation with Mexico, had no lasting influence, and after all was of a nature to discourage British agents. The theory of an active British governmental design upon California is then wholly without foundation. 


\section{INDEX.}

Aberdeen, Fourth Earl of, and British interests in Texas, 67 , 69, 7I-78, 79-80, 84-96, 100I04, I I 8-1 120, I 30-I 31 , I37147, I 56-160, I62-175, I80182 , I85-187, 190-195, 198200, 203-207, 219-221, 224225; and British interests in California, 239, 244-251.

Andrews, S. P., 137.

Annexation of Texas to U. S., see Texas.

Ashburton, Baron, 94-96, 24I (note).

Bankhead (British minister to Mexico), I54, I66-167, 176177, 184-185, 187-190, 202, 212-2I3, 22I, 222, 26I (note), 262.

Barron (British vice-consul), 236, 241-242, 250-251.

Blockade of Mexican coast by Texas, $8 \mathrm{I}-83$.

Bocanegra, J. M. de, I04-I05.

Boundary between Texas and Mexico, 27, 28, 33, 37, 42, 47-48, 168, 169, 171, 188, 207, 208.

Buckingham, James S., I 20-I 22.

Burnet, David G., 42-43.

Calhoun, John C., I6I-167, I82183.

Calhoun-Pakenham

correspondence, I 56-r67.

California, English interest in the annexation of, 234-264.

Canêdo, J. de D., 32, 44, 48, 49. Cass, Lewis, 25.

Cuevas (Mexican minister of foreign affairs), 201, 202, 22I222.
Donelson, A. J., 197, 215, 216-217. Doyle, Percy, British chargé in Mexico, 123-124, 134-135, 148, I 53 -I 54 .

"Eliza Russell," case of the, 34 . Elliot, Captain Charles, British chargé in Texas, 75 (and note), 106-116, x19, 124, 127129, $x_{3} 1-136, x_{39}$ (note), $148-$ I52, I 55, I6I, I65, I95-I96, 207-2I8, 223.

Everett, Edward, I43-I44.

Forbes, James, 237, 240-243, 250252.

France, interests of, in Mexico, 20-22; recognizes Texas, 20; share in tripartite intervention, 117-119; share in attempt to prevent American annexation of Texas, I 58-16o, 168-172, I74-175; withdrawal from plan, 18I-183, 190-191; agrees to offer joint mediation, 204 .

Gorostiza, M. E. de, 28, 44 .

Goulburn, Henry, 7 I-72.

Great Britain, refuses recognition of Texas, x 5-20, 23-25, 33-35, 63-72; relations with Mexico, I 5-I7, 20-22, 25-33, 6I-63, 98-106; attempt to make peace between Mexico and Texas, 26-33, 63-66, II7-119, ×38139, $148-150$; interest in suppression of slave-trade, 54-56, $59-60,67-68$; refusal to guarantee Texan-Mexican boundary, 42-43; treaties of peace between Texas and, 50, 52$56,58-60,63-65,67-76,85-86$, 87-88, 97-II7; Kennedy's mis- 
sion, 72-78; Aberdeen's policy toward Mexico and Texas, 7996 ; share in tripartite intervention, II7-122; the Robinson armistice, 128-137; desire that Mexico abolish slavery in Texas, 138-139; abol1tion plans for Texas, 139r5o; Calhoun-Pakenham correspondence, 156-167; Aberdeen's plan to prevent American annexation of Texas, 167-175; withdrawal from plan, 180-183, 185-187, I9019I; desire that Mexico offer and Texas accept recognition, 191-194, 198-199; proposal of joint mediation with France, 204-207, 208-218; acceptance of American annexation of Texas, 223, 224; refusal of aid to Mexico, 224-225; interest in annexation of California, 236-264.

Green, Duff, 140, 142.

"Guadeloupe," the, 83-93.

Gurley, R. R., 56 (and note).

Hamilton, James, and American annexation of Texas, 31, 3638 , 39-40, 50, 52-54, 67-70, $76-77,80,89$.

Henderson, J. Pinckney, 19, 20, 25.

Houston, Samuel, president of Texas, 8I-83, I 08, I I0-I I 4, I 24-1 26, 1 3 I-1 33,135 , I 5 , 195.

Hoy, Barlow, 16-17.

Jones, Anson, 118, 195-196, 20 I (and note).

Kennedy, William, $72-78,85$, I 7 , 180 (note).

"Little Penn," case of the, 34-35. Lizardi and Company, 26, 34, 51, 83-9r.

Martin, Capt. H., 99-100.

Mexico, British relations with, $15-17, \quad 20-22, \quad 25-33,61-63$; French interest in, 20-22; urged by England to recognize Texas, 26-33, 63-66, I1 7I 19, I 38-139, I48-1 50, I67I75, I87-190, 192-194, I98, 202, 205, 210-218; Hamilton's peace negotiations, $36-4 \mathrm{I}$, 5060 ; Treat's peace negotiations, 41-50; Aberdeen's policy toward, 79-81, 83-87, 88-93; British support of, 98-106; the Robinson armistice, I28I37 Bankhead in Mexico, 166-167; plan to reconquer Texas, I84-1 85; Bankhead's diplomacy, 187-190; refused aid by England, 224-225; relations with California, 237239, 242-243, 247-25I, 26I263.

“Montezuma," the, 83-92.

Murphy (representative of Mexico in England), 50 (and note), 83-9o, I 50-151, 167-168.

Pakenham, Sir Richard, minister to Mexico, 23 (and note), 24$25,26,27-29,32-33,38-50$, 61-66, 80-93, 97-99, 104-106, I23, 129-1 30, 177-180, 237240.

Palmerston, Lord, 16, 17, 19, 25, $29-31,35,39,42,52-56,58-$ 60,67 .

Paredes y Arrillaga, M., 262.

Reeves, J. S., 14, I13, I33 (and note), $195-196$.

Robinson, J. W., 128 (and note). Robinson armistice,' $128-137$.

Santa Anna, Antonio Lopez de, 65 (and note), 80, 105, $128-$ I29, $184-185$.

Santa Fé expedition, $8 \mathrm{I}$.

Seymour, Sir George, 254-259.

Simpson, Sir George, 24 I (and note).

Slavery in Texas, $16,17,29,31$, 56-57, 70, 74, I I I-I I 4, I $21-$ 122 , I32, I $37-150$, I 57, I62164,173 .

Slave-trade, British interest in 
suppression of, 54-56, 59-6o, 67-68.

Smith, Ashbel, and Texas, 85-92, II 8, II9, I40-I42, I70, 207.

“Tappan" committee, 138-139.

Texas, refused recognition by Great Britain, I5-20, 23-25, $33-35,63-72$; recognized by U. S., I8; by France, 20; slavery in, $16,17,29,31,56-$ 57, 70, 74, IIIIII , I I I-I 22 , 132, 137-150, I57, I62-164, I73; Great Britain's attempt to make peace between Mexico and, 26-33, 63-66, II 7I I9, I 38-139, I48-150; Hamilton's peace negotiations, 3641 , 50-60; Treat's peace negotiations, 4I-50; treaties of peace between Great Britain and, 50, 52-56, 58-6o, 63-65, $67-76,85-86,87-88,97-117$; Kennedy's mission, 72-78; Aberdeen's policy toward, 7983; Elliot in, Io6-116, I19, I 24-1 37; the Robinson armistice, I 28-1 37; Calhoun-Pakenham correspondence, I 56-167; Aberdeen's plan to prevent American annexation of, I67175; Anson Jones and the " Diplomatick Act," 195-196; urged to accept Mexican recognition, I98-199; proposed offer of joint mediation by
France and England, 205207; Elliot fails to prevent annexation, 208-218; annexation completed, 222 .

Treat, James, 4I, 43-50.

Treaties of peace, between Mexico and Texas, $31,38,39-41,43-$ 49; between Great Britain and Texas, 50, 52-56, 58-60, $63-65,67-76,85-86,87-88,97-$ I 77; between Great Britain and United States (Ashburton), 94-96.

Tyler, John, 197, 202, 203.

United States, recognition of Texas, 18; share in tripartite intervention, I I7-I 22; attitude toward alleged British interference in slavery in Texas, 143-144; offers annexation to Texas, I50-152; CalhounPakenham correspondence, 156-167; Senate rejects treaty with Texas, I77; popular desire for annexation, I78-180; Tyler's determination to complete annexalion, 197, 202, 203; indignation at Elliot's mission to Mexico, 214-218; annexation completed, 222; annexation of California, 251264.

Upshur, Abel P., I 50.

Warburton, George, I I6 (note). Webb, James, 64 .

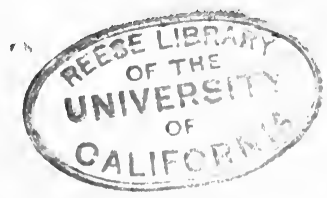





